\title{
Archaeological Studies at the CPS Butler Lignite Prospect, Bastrop and Lee Counties, Texas, 1983
}

Kenneth M. Brown

Follow this and additional works at: https://scholarworks.sfasu.edu/ita

Part of the American Material Culture Commons, Archaeological Anthropology Commons, Environmental Studies Commons, Other American Studies Commons, Other Arts and Humanities Commons, Other History of Art, Architecture, and Archaeology Commons, and the United States History Commons

Tell us how this article helped you.

This Article is brought to you for free and open access by the Center for Regional Heritage Research at SFA ScholarWorks. It has been accepted for inclusion in Index of Texas Archaeology: Open Access Gray Literature from the Lone Star State by an authorized editor of SFA ScholarWorks. For more information, please contact cdsscholarworks@sfasu.edu. 


\section{Archaeological Studies at the CPS Butler Lignite Prospect, Bastrop and Lee}

Counties, Texas, 1983

\section{Creative Commons License}

\section{(c) (1) \&}

This work is licensed under a Creative Commons Attribution-NonCommercial 4.0 International License 


\section{Arehaeological Studies at the}

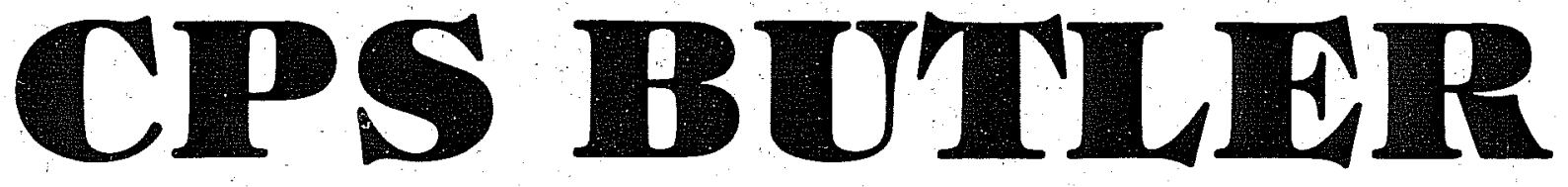

Lignite Prospect, Bastrop and Lee Counties, Texas,

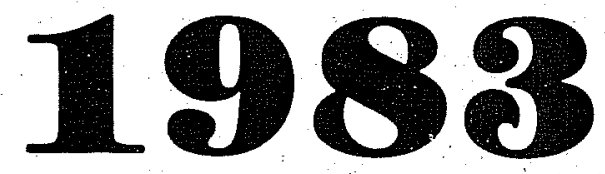

Kenneth $M$. Brown

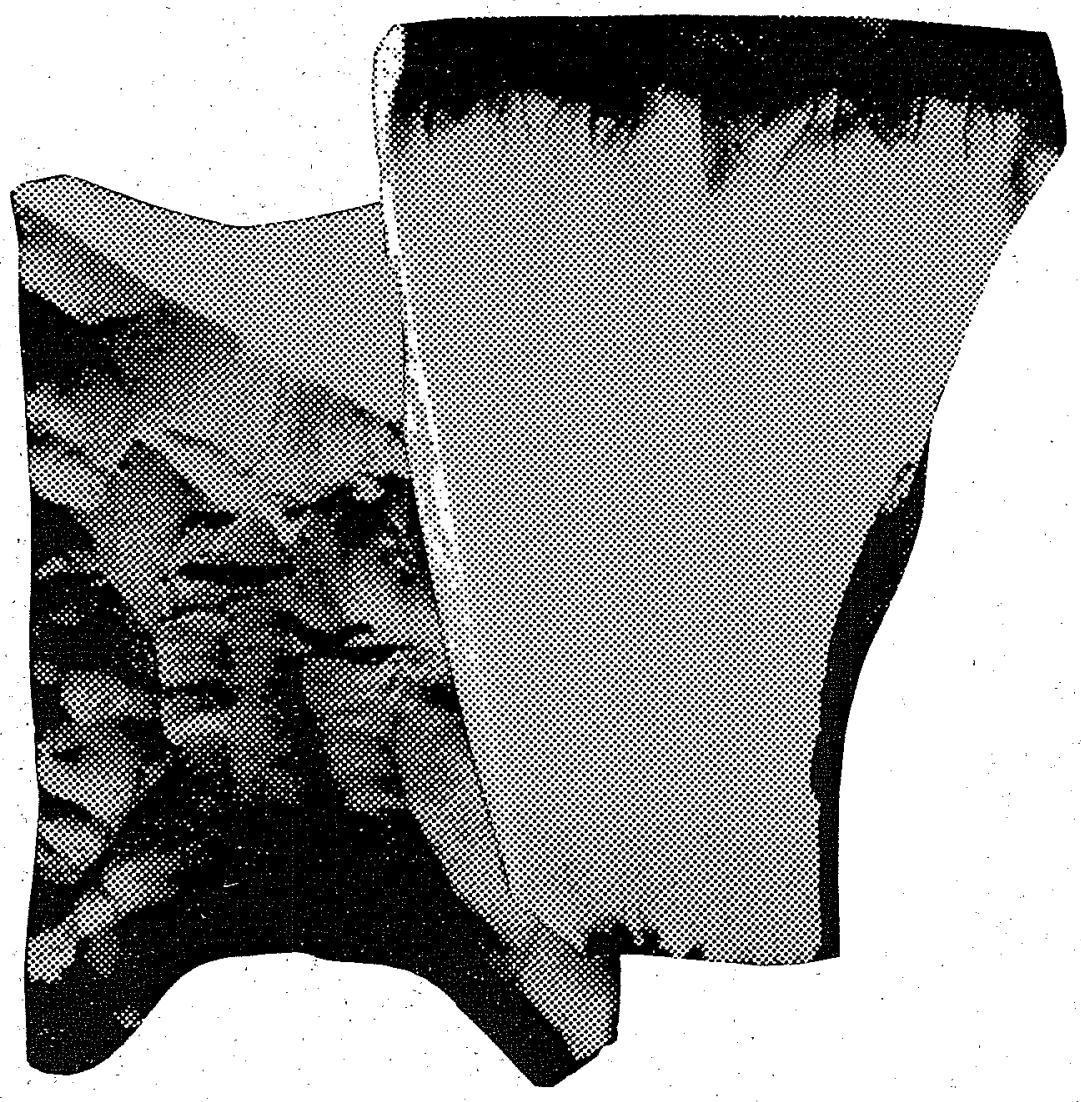

Center for Arelhaeological Research The University of Texas at Sam Antonio Arehaeological Survey Report, No. 140 1986 



\section{ARCHAEOLOGICAL STUDIES AT THE \\ CPS BUTLER \\ LIGNITE PROSPECT, BASTROP AND \\ LEE COUNTIES, TEXAS, \\ 1983}

Kenneth M. Brown

Texas Antiquities Committee Permit No. 346

Thomas R. Hester, Principal Investigator

Center for Archaeological Research The University of Texas at San Antonio ${ }^{(}$ Archaeological Survey Report, No. 140 
The following information is provided in accordance with General Rules of Practice and Procedure, Chapter 41.11 (Investigation Reports), Texas Antiquities Committee:

1. Type of investigation: archaeological survey, testing, and historic cemetery documentation;

2. Project name: CPS Butler Lignite Prospect, Phase II and III Survey and Testing;

3. Counties: Bastrop and Lee Counties, Texas;

4. Principal Investigator: Thomas R. Hester;

5. Name and location of sponsoring agency: City Public Service, San Antonio, Texas;

6. Texas Antiquities Committee Permit No. 346;

7. Published by the Center for Archaeological Research, The University of Texas at San Antonio, San Antonio, Texas 782850658, 1986.

A 1 ist of pub 1 ications offered by the Center for Archaeological Research can be obtained by sending $\$ 1.00$ to the Center for Archaeological Research, The University of Texas at San Antonio, San Antonio, Texas 78285-0658. 


\section{ABSTRACT}

In May and June 1983, archaeologists from the Center for Archaeological Research, The University of Texas at San Antonio, performed a pedestrian survey intended to provide $100 \%$ coverage of 288 hectares of 1 and in the CPS But 7 er 1 ignite prospect. The survey area was divided into five separate tracts in Bastrop and Lee Counties; four of these tracts had been examined in an earlier reconnaissance-level survey, and the present survey was intended in 1 arge part to emphasize heavily vegetated areas not thoroughly covered by the earlier survey. Five sites were located; all had some prehistoric cultural debris, but two were chiefly mid- to 1 ate 19th-century historic sites. Three sites recorded by the earlier survey were briefly reexamined, but a fourth could not be relocated. In Ju1y, Morgan Chapel Cemetery, a 1 ate 19 th/early 20 th-century cemetery associated with a now-vanished Methodist church, was mapped and documented in preparation for a planned relocation. Concurrentiy, a prehistoric site located by the survey in May was also tested. This site, $41 \mathrm{BP} 264$, has produced an interesting surface collection that includes a Plainview point, a Clear Fork tool, and a variety of ground stone artifacts, but appears to have been completely disturbed by sand quarrying operations.

KEYWORDS: Bastrop County, Lee County, Morgan Chapel Cemetery, prehistoric archaeology, historic archaeology 
TABLE OF CONTENTS

ABSTRACT . . . . . . . . . . . . . . . . . . . . . . .

LIST OF FIGURES ..........................

LIST OF TABLES .......................... ... 1 ...

ACKNOWLEDGMENTS ........................ . . . . iv

INTRODUCTION . . . . . . . . . . . . . . . . . . . . . . 1

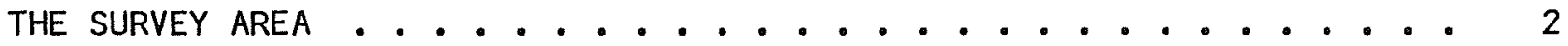

PREVIOUS ARCHAEOLOGICAL RESEARCH . . . . . . . . . . . . . . . 5

CHRONOLOGY OF SETTLEMENT ...................... . . . . 6

THE PHASE II TRACTS ........................... 8

SURVEY AND DOCUMENTARY SEARCH METHODS . . . . . . . . . . . . 13

THE SITES . . . . . . . . . . . . . . . . . . . 14

41 BP 264 . . . . . . . . . . . . . . . . . . . 14

Artifacts ..................... 18

Conclusions and Recommendations for 41 BP 264 . . . . . . 26

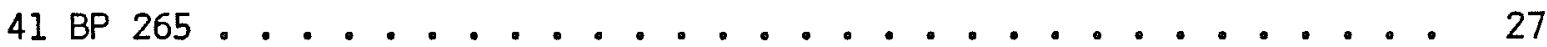

41 LE 73 . . . . . . . . . . . . . . . . . . . 27

Prehistoric Component . . . . . . . . . . . . . . 28

Historic Component (Milis Homestead) . . . . . . . . . . 33

History of Land Ownership ................. 39

Recommendations for 41 LE 73 ...................... 43

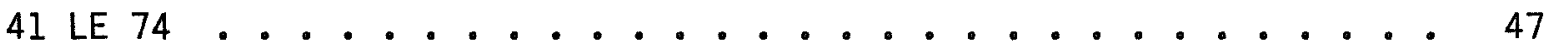

Recommendations for 41 LE 74 ................ 48

41 LE 75 . . . . . . . . . . . . . . . . . 4 48

Ceramics........................ 48

Glass . . . . . . . . . . . ....... . . 52

History of Land Ownership ................... . . 52

Summary and Recommendations for 41 LE 75 . . . . . . . . . 55

ISOLATED FINDS .......................... 55

Tract 2 . . . . . . . . . . . ............ 55

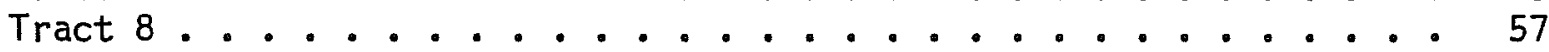

MORGAN CHAPEL CEMETERY ..................... 58

Description of the Cemetery .................... 61

Descriptions of Individuat Graves . . . . . . . . . . . . 63

SUMMARY, CONCLUSIONS, AND RECOMMENDATIONS . . . . . . . . . . . 72

Prehistoric Occupations . . . . . . . . . . . . . . . 74

Historic Occupations . . . . . . . . . . . . . . . 76

Recommendations . . . . . . . . . . . . . . . . . 78

Peat Bogs as an Archaeological Resource . . . . . . . . . . . 79

REFERENCES CITED .............................. . 80

Appendix A. Inventory of Surface Collection from 41 BP 201 . . . . . . 93

Appendix B. Inventory of Surface Collection. Tract 8, North of

Highway 696 and South of Willow Creek . . . . . . . . . . . . 94 


\section{LIST OF FIGURES}

1. Phase II Survey Area, Showing Numbered Tracts and Sites Recorded . 3

2. The Cruse House (4I BP 203) as it Appeared While Being Dismantled in November 1984 . . . . . . . . . . . . . . . . . . 12

3. Plan of 41 BP 264, Showing Test Pits, Shovel Tests, and Surface

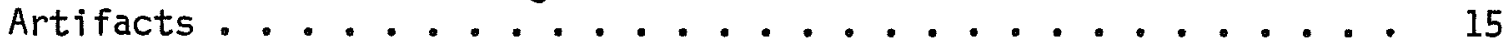

4. Soil Profile in Shovel Test 1 at 41 BP 264 ........... . 17

5. Prehistoric Artifacts from 41 BP 264 . . . . . . . . . . . . . 21

6. Ownership in 1860 of Land Comprising Tract 8 . . . . . . . . . 29

7. Ownership in 1880 of Land Comprising Tract 8 . . . . . . . . . . . 30

8. Sketch Map of 41 LE 73, With Shove1 Tests 1 and 2 Shown . . . . . 31

9. Historic Ceramics from the Mills Homestead, 41 LE 73 . . . . . . . 37

10. Prehistoric and Historic Artifacts, 41 LE 73 . . . . . . . . . 41

11. Historic Artifacts, 41 LE 75; Tract 8 Isolated Finds ....... . 51

12. Isolated Rock Pile in Tract 2 and Views of Survey Area in

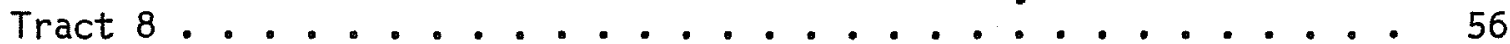

13. Plan of Morgan Chapel Cemetery . . . . . . . . . . . . 60

14. Morgan Chapel Cemetery ............... . . 66

15. Morgan Chapel Cemetery ................... . 70

16. Tract Maps Showing Phase II Survey Intensity . . . . . . . . . 73

\section{LIST OF TABLES}

1. Surface Chipping Debris, 41 BP 264 . . . . . . . . . . 25

2. Excavated Chipping Debris, $41 \mathrm{BP} 264$. . . . . . . . . . 26

3. Surface Chipping Debris, 41 LE 73 ............... . 32

4. Surface Historic Debris, 41 LE 73 . . . . . . . . . . . . . 34

5. Excerpted Federal Census Records for 1850 and 1860 . . . . . . . 44

6. Agricultural Production in 1860 by Landowners in the Prewitt, Mauldin, Bankston, and Adjacent Surveys . . . . . . . . . 46

7. Surface Chipping Debris, 41 LE 74 ............. . . . 47

8. Surface Historic and Prehistoric Debris, 41 LE 75 . . . . . . . . . 49

9. Transactions Involving Parcel 1 (Part of the Prewitt Survey) in

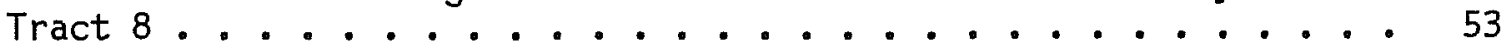

10. Prehistoric Site Density in the Post Oak Belt . . . . . . . . . 75 


\section{ACKNOWLEDGMENTS}

Special thanks go to Anne Fox at the Center for Archaeological Research, who looked at my historic artifacts and told me what I had after I had picked them up, and to Jim Odiorne of Bastrop, who furnished very usefut information on Morgan Chapel Cemetery. Jim Markey identified the marine shells from one of the graves at the cemetery. Donaly E. Brice (Reference Specialist, Texas State Archives) 1ocated William Cruse's date of death for me. Col. Harold Simpson. Director, Hill Junior College History Complex, provided a muchneeded reference for the history of Waller's Battalion. Dr. Georgeanna Greer very kindly spent part of a cold winter afternoon identifying stoneware sherds from the survey area and filling me in on what she has learned about the early potters of the area. Bil1 Woodward, a San Antonio black powder enthusiast, identified a lead projectile from one of the historic sites for me. Beth Craig graciously loaned me her darkroom facilities. Dr. Thomas R. Hester and Jack Eaton provided administrative help. And, of course, thanks to crew members Paul Lukowski and Marlene Syverson. 


\section{INTRODUCTION}

City Public Service (CPS) of San Antonio owns several 1 arge tracts of 1 and north of Butler, Texas, in Bastrop and Lee Counties and plans to strip mine these tracts to obtain 1 ignite for power generation. In 1981, CPS' Generation and Environmental Planning Department contracted with the Center for Archaeological Research, The University of Texas at San Antonio (CARUTSA), to carry out a phase I archaeological survey (that is, a reconnaissance, involving only partial coverage of the area, and designed simply to give an overview of its archaeological contents) of eight tracts comprising 770 hectares ( 1900 acres) of 1 and. The survey was carried out by Thomas Kel $1 y$ and Erwin Roemer, Jr., in July 1980, and is reported in Kelly and Roemer (1981). Because some of the tracts have priority for more immediate development as 1 ignite prospects and were scheduled for early brush clearing, CPS in February 1983, requested that the Center perform a phase II survey of four of the tracts (1, 2, 5, and 8); 1ater an additional new tract (19) which had not been covered by the phase I survey was a 1 so added. Because some of the original tracts had been expanded by further 1 and acquisitions, the phase II survey covered 288 hectares ( 711 acres). Since the phase I survey had emphasized areas clear of vegetation, the new survey was intended to concentrate on the more thickly vegetated parts of the tracts (1etter, Grant Ha 11 to Martin Clausewitz, March 14, 1983).

The phase II survey was done by Ken Brown and Marlene Syverson from May 23-25 and May 30-June 1, 1983. Five sites were located; two of these were in the new tract (19), which had never been examined before, and the other three were in tract 8. All of the sites had some prehistoric cultural debris, but two were primarily mid- to late 19th-century historic sites. Two sites recorded by the phase I survey (4I BP 199 and 41 BP 201) were also reexamined briefly. Morgan Chapel Cemetery (4l BP 200), a late 19th-century/early 20thcentury cemetery located near the northern corner of tract 1, was briefly examined and recorded by Erwin Roemer, Jr., in 1980 (Kelly and Roemer 1981:14-18), and since it is in an area to be affected by mining, CPS planned to relocate the cemetery, with monitoring of the relocation project to be done by the CAR. A crew consisting of Ken Brown, Paul Lukowski, and Marlene Syverson mapped and recorded above-ground aspects of the cemetery on July 67. 1983, and a 7 so further tested a prehistoric site (41 BP 264) 1ocated by the phase II survey. The testing and cemetery documentation project together constitute phase III of the CPS Butler project. The actual relocation (phase IV) was done in August 1984, by $A$. J. Taylor and others and is reported in Taylor, Cox, and Fox (1986); on $1 y$ the above-ground aspects of cemetery documentation are dealt with in the present report.

Both phases II and III were done in compliance with the National Historic Preservation Act of 1966 (as amended) and its implementing regulations, 36CFR800, the National Environmental Policy Act of 1969, and Executive Order 11593, and were carried out under Texas Antiquities Committee Permit No. 346. Assessments of the sites for eligibility for nomination to the National Register of Historic Places are discussed in the section entitled "Summary, Conclusions, and Recommendations." Both phases were done under the supervision of Thomas R. Hester (principal investigator) and Jack Eaton (coprincipal investigator). Artifacts collected are permanently housed at the Center for Archaeological Research. 


\section{THE SURVEY AREA}

The survey area is located in northern Bastrop County, northeast of Butler, Texas, and extends across the county 1 ine into Lee County; tract 8 1ies entirely in Lee County (Fig. 1). The substrate over the project area is the Calvert Bluff formation, consisting in the subsurface of mudstone with sandstone, 1 ignite, ironstone concretions, and occasional1y glauconite (Bureau of Economic Geology 1974) but where exposed in the project area, usual1y expressed as compact sandy clay, varying from bright orange to blueish gray mottled with orange. Elevations range from about 470-560 feet above mean sea level (MSL) in the project area, a 1 though the Yegua Knobbs (Carrizo Fm) to the east range up to 760 feet. There is 1 ittle sandstone exposed in the project area itse $1 \mathrm{f}$, except for outcrops of 1 ight gray, homogeneous finegrained, poorly indurated sandstone exposed in sand pits in tract 19. Sma11 blocks of ferruginous sandstone, however, can occasionally be found on the surface in various areas. Except where the soil profile has been partially or wholly removed by erosion, the area is characterized by deep, 1oose, sandy soils developed on a compact clay substrate with contacts that are often quite abrupt. Nearly all our shovel tests were in colluvium or in these deep in situ sandy soils, general1y 30 to $60 \mathrm{~cm}$ deep where not a 1 tered by erosion. One shovel test just north of Willow Creek, however, penetrated $107 \mathrm{~cm}$ of alluvial sand before striking ironstone gravels and clay-rich sand. Soils in the project area include Demona loamy fine sand, Axte 11 and Crockett fine sandy loam, Tabor fine sandy loam (in gallery areas flanking the headwaters of creeks), and Sayers fine sandy loam (developed on alluvial sand in gallery areas of 1 arger creeks). Gu 11 ied areas and sheet-washed areas where the subsoil is exposed are fairly common, especially in tract 8, where for example the entire hillside on which one archaeological site 1 ies shows wholesale down slope shifting of the topsoil, which has collected behind 1 arge agricultural terraces, 1 ater breached by massive gu 11 ies.

The loose, sandy soil, the high potential for erosion, and the impermeability of the subsoil have created a number of 1 ocal vagaries in the water table. We noted several places where rapid deposition of sand by tributaries had created smal1 natural dams across drainages, forming smal1 ponded areas. In one case, the dam was an obviously recent response to gullying in the field mentioned earlier. A larger example, however, located at the northwest edge of tract 8, seems to be entirely natural and appears at least a decade or two 01d, if not older--there a sma 11 swamp has been created. Localized, perched water tables are related phenomena and are fairly common in the area (Martin Clausewitz, personal communication). An example is present at one archaeological site (41 BP 264) located by the phase II survey; here a smal1 ponded depression at 510 feet elevation, a good eight meters above the adjacent creek, holds water in wet seasons, probably derived from groundwater as well as surface runoff. If this feature is as old as the archaeological occupation, it may help explain why an area so distant topographically from running water was occupied.

In Ju1y 1846, Ferdinand von Roemer traveled from Bastrop to Caldwell along the $01 \mathrm{~d}$ Spanish Road (now Highway 21), passing about $20 \mathrm{~km}$ southeast of our study area. His route took him first through the Lost Pines, then into the post oak woodland, and once over the Yegua, onto the San Antonio Prairie. Roemer wrote, 
This page has been

redacted because it

contains restricted

information. 
On the other side of the hill where the undulating ground is less fertile, post oaks take the place of the pines, and for the next forty miles form at first a continuous forest which later on alternates with smal1 prairies. We rode all day without seeing a house, and made our camp in the evening on the banks of the Yegua, a sluggish muddy river enclosed by a broad forest bottom....

The forest ended about fifteen miles this side of Caldwell and we entered a wide prairie, called the San Antonio Prairie. On its rim, we saw isolated farms--the first we had seen since leaving Bastrop (Mue 11 er 1935: 185-186).

This quotation is of interest because it shows, first, that the biomes recognizable today were present in the 1840s, at the onset of Anglo settlement, and second, that the initial settlement occurred in the prairies and avoided the deciduous forest belt.

The project area is part of a region usual 1 y shown on synoptic vegetation maps as "post oak savanna" (Gould 1975), although the term is somewhat inappropriate here because of the rolling to hilly relief and locally dense wood 1ands. "Remnant post oak woodland" would probably be a better generic label for the local vegetation. The northwest edge of the post oak be 1t runs about four kilometers northwest of the project area. Despite modern clearing and 1 andscape transformation it is stil1 a highly visible geographic boundary between the calcic blackland prairie soils developed on Cretaceous marl in Williamson County and northeastern Travis County, and the deciduous wooded, calcium-deficient sandy soils developed on Eocene deposits in Bastrop and Lee Counties. Only the westernmost corner of Lee County sticks out into the blackland prairie. The narrower and less extensive San Antonio and String prairies, to the east, 1 ie on Eocene deposits.

The project area 1 ies in a corridor settled by Anglo-American immigrants, many of them from the up 1 and South. The area to the east, covering most of Lee County, was settled chiefly by Wends; the blackland prairie area to the northwest in WiTliamson County and to the west, in northeast Travis County, was settled by German and Swedish immigrants (Arbingast et a1. 1973:42). In the days before gas fuel, many rural settlers on the prairie also owned wood land plots in the post oak belt that were reserved as woodlots to supply firewood (Erwin Roemer, Jr., and Geraldine Ross, personal communication).

The survey area includes several different altered habitats: recently abandoned fields, old fields invaded by mesquite and cedar and now used as pasturage, dense gallery woodlands along stream courses, and slightly more open wooded tracts on valley slopes. The woodland areas are dominated by post oak and blackjack oak, water oak, prickly ash, hickory, elm, eastern red cedar, yaupon, and hackberry, along with mustang grapevine, greenbriar, poison oak or ivy, frostweed, and a variety of other understory plants. Willows, large hackberries, sycamores or pecans may be found along the stream channe1s. The loblolly pines characteristic of the central part of Bastrop County and the 1 ive oaks found in the southern part are almost wholly absent here. 
Cleared areas have scattered eastern red cedar, post oak, mesquite (sometimes forming thickets), and dewberry vines, with dense mixed grasses and forbs in floodplain meadows and with grasses (varying in density according to the amount of erosion), rattlebean, and other plants on more sloping, upland areas. Most of the project area has been cleared for farming at some time during the 1 ast 120 years. For the most part, undisturbed woodlands are confined to gallery areas, fringing the intermittent streams in the area, that correspond closely to the flood zones of the streams. Some of these bottom 1 and woods are dense, nearly impenetrable tangles of vines, briars, standing and downed trees that can be traversed on 1 y by b 7 azing a machete trail or by following existing catt1e tracks; good examples were found in tracts 8 and 19. In these areas the vegetation is more reminiscent of east or southeast Texas bottom 1 ands than of central Texas (Fig. 12,C). Annua 1 rainfall here is about $86 \mathrm{~cm}$ (34 inches). More detailed descriptions of regional vegetation can be found in two environmental impact reports. A report by the Tera Corporation (cited in Ske1ton and Freeman 1979:Tab 1e 1) identifies four plant communities for the Camp Swift area: post oak-red cedar woodlands, mesquite brushland, old fields, and riparian zones. A description of the post oak belt in Bastrop, Lee, Milam, and Freestone Counties by Holm (1975:7-12) 1 ists vegetation by up 1 and, bottom 1 and, and ephemeral stream habitats.

Only willow Creek in tract 8 is a perennial stream (here, a second to thirdorder stream depending on 1 ocation); a 11 others in the project area are intermittent, although several have been dammed for stock ponds and retain standing water. Drainages in tracts 5 and 8 are tributaries of Willow Creek, which drains northeast into Middle Yegua Creek in Lee County. Drainages in tracts 19, 1 , and 2 are first-order tributaries of Big Sandy Creek, which drains southward to the Colorado River.

Pol len cores from Boriack bog, $13 \mathrm{~km}$ east of tract 8, record over 15,000 years of vegetation history. Samples immediately above a level radiocarbon dated at about 10,000 B.P. show a sharp increase, then the disappearance of alder pollen associated with a significant increase in grass pollen continuing to the present. Juniperus pollen appears only at the top of the column, perhaps suggesting eastern red cedar is a recent introduction to the area(?). Otherwise, the same kinds of vegetation were present then as now, only in somewhat variant proportions (Bryant 1969:Fig. 7).

\section{PREVIOUS ARCHAEOLOGICAL RESEARCH}

Most of the previous archaeological research in Bastrop County has been done in preparation for planned 1 ignite strip-mining projects or power transmission 1 ines. Aside from the earlier survey at Butler by Kelly and Roemer (1981) and the most recent one by Taylor (1986), the nearest and most relevant surveys are those of Dibble (1976) and Ske1ton and Freeman (1979) at Camp Swift. Farther to the south, sma11 areas have been surveyed by Fawcett (1975), Prewitt and Laurens-Day (n.d.), Prewitt and Kotter (n.d.), Kegley (n.d.), Prewitt (n.d.), and Nightengale (1980). At the Powel1 Bend 1 ignite prospect in the lower drainage of Big Sandy Creek, the Texas Archeological Survey has carried out a series of projects ranging from survey to ful1-scale excavation (Kenmotsu 1982; Robinson 1983; Bement 1984). Severa1 projects 
have been done in the southern part of the county along the Fayette-to-Lytton Springs transmission 1 ine (Kenmotsu and Freeman 1980; Brown and Kenmotsu 1980). Other transmission 1 ine projects include Laurens, Guy, and Prewitt (1979) and Brown (1984). One project by the State Department of Highways and Public Transportation has been done near Smithville (Goode 1984). The eastern part of the county and the southern part, between the Colorado River and the Fayette-to-Lytton Springs transmission 1 ine, have received 1 ittle archaeological attention.

\section{CHRONOLOGY OF SETTLEMENT}

European incursions into what is now Bastrop County were infrequent before the founding of Spanish missions in east Texas. After the establishment of Mission San Francisco de 105 Tejas (1690, in Houston County) and especial1y after the founding of Nacogdoches in 1716, trave1 became more frequent, but sti 111 argely confined to the Camino Rea 1, which fol 1owed the San Antonio Prairie along the route of modern Highway 21 from San Marcos to Bastrop to Caldwel1. Other parts of the county were visited occasionally, as when the Espinosa-01 ivares-Aguirre expedition (1709) fol10wed the Colorado River downstream nearly as far as present-day Bastrop. This expedition also recorded a rancheria in eastern Travis County comprised of displaced Yojuane, Simaomo, and Tusonibi Indians encamped with a number of Cantona Indians who were probably native to the region (Campbe11 1983). Pages, in 1767, recounts:

- . We came to the crossing of the red river or Colorado, which appeared to me considerably larger than the two others, both in width and in speed. We were then abundantly supplied with beef and venison, and we lived almost solely on meat. That part of the country is formed of vast prairies cut by smal1 rivers or streams some distance from each other (Pages 1985:16).

The earliest settlement was apparently a stockaded military garrison, the Puesta del Colorado, established in 1805 at the present site of Bastrop by the governor of Texas, Cordero y Bustamante, and 1ater abandoned because of Indian raids (Webb 1952, Vol. 1:121). Evidently this was not a very substantial garrison, since in June 1806, the combined strength of this post and two others on the Guadalupe and San Marcos Rivers was on 1 y 30 (Moore 1977:16), and in November of the same year stood at 35 troops (Faulk 1964:41). In 1807, Zebul on Pike, returning from Mexico, noted the fort was manned by dragoons, with lodges of "Tancard" Indians around it (Moore 1977:16). In September 1807, Comandante General Salcedo in Chihuahua approved arrangements for treatment at the Puesta of the sick from the detachment at the Atascosito Road crossing, farther down the Colorado River toward the coast (Fitzwi11iams 1955:4). In August 1821, Stephen F. Austin crossed the Colorado River on the Camino Real and observed that "the bottom where the road crosses is about five miles, mostly high prairie, clear of overflow, 1 and rich, timber Pecan, Ash, Oak, Cedar, abundance of fish" (Austin 1903:295) but does not mention any visible evidence of the abandoned Spanish post. Mary Raab (1962) gives an evocative account of 1 ife in the Colorado River valley of 1823, at Indian Hill in Fayette County. It was apparently not until 1829, however, that an enduring settlement was made at 
Bastrop, then called Mina, by William Barton, Josiah Wilbarger, Reuben Hornsby, and others destined to lend their names to local 1 andmarks (Webb 1952, Vo1. 1:120). Berlandier (1980:338-340), traveling through the Lost Pines from northeast to southwest and crossing the Colorado River on June 12 , 1828, does not mention any settlements, though he may have strayed from the $01 d$ Spanish Road; some Tahuacano (Tawakoni) Indians were sighted, however. Smithwick (1983:11), although not specifying a date, recorded that at about this time Burnham's Station (below LaGrange) was the "highest settlement on the river." Woods' Fort, near West Point, and Moore's Fort, at LaGrange, were reported $1 y$ estab 1 ished about 1828 (Jenkins 1958:260; Pierce 1969:182). Alum Creek, northwest of present Smithville, was settled about 1828 by seven families from Missouri, who built a fort near the mouth of the creek (Moore 1977:189; Vasey 1979a). One of these settlers, John Ridgeway, 1ater moved to the north and built his own fort farther up Alum Creek, presumably near Ridgeway Community, southwest of the intersection of present US 290 and Highway 21 .

The ear 1 iest homesteads, beginning in the 1830s, were supported by sma 11 plots of corn, supplemented by very smal1 crops of cotton (Jenkins 1958:19) and were subject to constant Indian raids. Lincecum mentions seeing "two experiments in the cotton plant in the Swamps of the Colorado" somewhere near Bastrop in February 1835 (Bradford and Campbe 11 1949:191), a 7 though Caton Erhard, a German immigrant who arrived in Bastrop in 1840, claimed no cotton was raised in the county unti1 1841 (Menn 1955:10). Latham (1971:20) gives an interesting and detailed description of the farm of John Burleson as it appeared in May 1842. This farm on the Colorado River bottom supported both cotton and corn, the latter double-cropped and yielding 30 to 40 bushe1s per acre. Both Jenkins (1958) and Smithwick (1983) give vivid accounts of the beginnings of Ang 10 settlement and the early history of Bastrop, a part of Stephen F. Austin's "Little Colony." The first tracts settled were, of course, the bottomlands of the Colorado River and its principal tributaries, such as Big Sandy Creek, Wi 1 barger Creek, and Cedar Creek; many immigrants settled in the town of Bastrop itse $1 \mathrm{f}$. Recruitment was probably chiefly from the plantation South. The earl iest settlers avoided the lowest terraces, termed "bottoms," choosing instead to break ground on the higher, betterdrained terraces, which were termed "prairies" 1 ike their up 1 and counterparts. Hills Prairie, Crafts Prairie, and David Bottom, all between Bastrop and Smithville, are geomorphic units stil1 bearing their early names.

The municipality of Mina was formal1y recognized by the Mexican government in 1834, and Mina County was created in 1836 and renamed Bastrop County in 1837, when the town of Bastrop was also incorporated and named after Fel ipe Enrique Neri, the Baron de Bastrop (Webb 1952, Vo1. 1:120; Vol. 2:204). Several structures in Bastrop's historic district, such as the home of Governor Sayers (begun ca. 1830), the Jenkins house (ca. 1832), and the Greenleaf Fisk house (ca. 1836), remain from this period. Lincecum reported in 1835 that "there is a Steam mi11 now being erected on the east side of the Colorado between Bastrop and Electra" (Bradford and Campbel1 1949:199) but the exact location is not specified. In an even earlier account, Joseph Clopper (1909:64) had reported a gristmil1 and "the frame of a saw mi11" near Beason's Ferry in what is now southeastern Colorado County in 1828, but does not identify the power source. By 1838, the Bastrop Steam Mil1 Company had been incorporated (Webb 1952, Vo1. 1:120) and by January 1840, there were two 
steam sawmills in operation, the beginning of the local lumber industry, and an agent at Bastrop was advertising 1 umber in the Austin Gazette (Moore 1977:175). Both of these were shut down by 1842, however, because of 1 ack of trade and money (Menn 1955:10). Early mill operators were J. C. Higgins and R. H. Grimes (Jones 1936:18). Most of the early sawmi11s a 1 so had sma 11 gristmil1 attachments for milling smal1 amounts of corn. Cotton gins were also reportedly in operation in Bastrop County by this time (Moore 1977:181). At least one cabinetmaker was also in operation by 1840, producing spinning wheels, clock reels, and chairs (Taylor and Warren 1975:301).

The beginnings of steamboat service on the Colorado River are not wel1 documented. According to Wi11iams (1961:41-42, cited in Kel1er and Campbe 11 1984:48) the David Crockett successfully navigated from Bastrop to the Colorado River raft above Matagorda in 1838. By 1846, the steamboat Kate Ward had successfully ascended the Colorado River to Austin; other commerce on the river employed keelboats and flatboats to ship cotton, hides, pecans, and 1 umber (Hogan 1969:78-79). Other steamers such as the Colorado and the Water Mockasin operated on the river in the mid-1850s (Moore 1977:92). By 1850, over 18,000 head of cattle were reported for the county (Texas Almanac 1857). The Bastrop Academy opened in 1851, and a newspaper, the Colorado Revel11e, predecessor to the Bastrop Advertiser, began publication the same year; the first 1 ibrary was established in 1852. By 1856, post offices in the county included Alum Creek, Bastrop. Cedar Creek, Cunningham's, Perryville, Sand Fly, and Young's Settlement (Texas Almanac 1857). The post office at Young's Settlement was established in 1849 (Moore 1977:269). Bastrop Military Institute was founded in 1858, and a Confederate armory was in operation by 1862, with Bastrop gunsmith N. B. Tanner supp 7 ying Mississippi pattern rifles under state contract (Moore 1977:80).

Settlement spread to the rest of the county beginning in the 1840s, although the only substantial area where the chronology of settlement has been studied is Camp Swift (Skelton and Freeman 1979; Smith and Pannel1 1984), where the earliest, though 1 imited, settlement began about 1839. Many sma 11 communities in the county, such as Cedar Creek, Rosanky (originaliy Snake Prairie when its post office was established in 1871), String Prairie, Red Rock, and others were established as farming communities in the 1850 s, although the date of incorporation of a community is not a good guideline for the earliest dispersed settlement in an area (see Vasey 1979b for a brief history of Rosanky). Another string of communities such as Elgin, Butler, and Paige in the northern part of the county were incorporated with the arrival of the rail road.

\section{THE PHASE II TRACTS}

Iract 19 (33 hectares, 81 acres; previously unsurveyed): This is the southernmost tract, adjoining Highway 696 on its east side and extending $1.5 \mathrm{~km}$ to the east-southeast. Most of the tract was put in improved pasture by Frank Schindler and has a very heavy, thick cover of coastal Bermuda. Although it was not immediately apparent at the beginning of our inspection, much of this tract has been quarried by the Butler Brick Company to obtain sand as a tempering agent for bricks. The sandy ridges on which both sites (41 BP 264, 41 BP 265) in the tract 1 ie have been quarried extensively. Near 
$41 \mathrm{BP} 265$, the ground surface has been cut down about two meters a long the north fenceline. A smal1 drainage bisects the tract diagonally and is dammed to form a smal1 permanent 1ake. Adjacent to it is a mound of Butler bricks surrounding an old cement cistern. A 1 arger drainage cuts across the east corner of the tract and, although intermittent, supports the densest woodlands seen in the survey. On the west side of these bottom 1 and woods is a single very large pine tree surrounded by a stand of smal1 pine saplings; these are the only pine trees noted in the project area. The floodplain on the east side of the drainage has been cleared but not disturbed 1 ike the rest of the tract. The two prehistoric sites located in this tract are described Tater.

Iract 1 (78 hectares, 193 acres; estimated $90 \%$ coverage in phase I): This tract also lies mostly on the east side of Highway 696 which cuts across its northern corner and joins tract 19 on the north. It is bordered on the north and east sides by an old county road now closed to public traffic. This tract is almost wholly in unimproved pasture except for narrow belts of post oak along drainages, with a smal1 tract of open woodland on the east side of the easternmost drainage. The two southward draining intermittent creeks that cross tract 19 also cross this tract; both have large tanks with standing water. Erosion is moderate to severe over much of this tract due to long-term overgrazing. Most of it has eroded Crockett soils or Axtel 1 fine sandy loam, except for drainage bottoms and the high sandy ridge at the west corner of the tract (Baker 1979). A dense thicket of mesquite has invaded the east end of the tract. Grass cover is thin in most areas because of $105 s$ of topsoil, and ground visibility is consequently good. A complex of abandoned 20th-century farm buildings (Wolf homestead) occupies the center of the tract.

No new sites were found in this tract, although one site (41 BP 199) located by the phase I survey was reexamined.

Iract 2 (40 hectares, 100 acres; estimated 75\% coverage in phase I): This tract a 1 so 7 ies on the east side of Highway 696. Most of it consists of unimproved pasture. One of the creeks crossing tract 1 heads along the east side of this tract, and is bordered by fairly open post oak woodland. Another smal1 drainage cuts across the northeast corner, enclosing a sma 11 but dense post oak woodland. An abandoned field occupies the west quadrant, between the creek and the highway. The center of the tract is occupied by a hi11 (at 560 feet) on which another Wolf homestead (41 BP 201, early 20th century) formerly stood. The foundation blocks and chimney are stil1 standing. East of the house site is the double-crib barn reported by Kelly and Roemer (1981:Fig. 6,a). Presumably both pens were joined by a single roof, although both doors face west while the more usual arrangement in double-crib barns is to have both doors facing each other. Both cribs are made of logs from what appear to be 1 arge post oaks about 9 to 10 inches in diameter; the larger wall logs are split in half. Corner notching in both cribs is V-cut, which Jordan (1978:65, Fig. 4-14) maintains is characteristic of settlers of "upper southern" and German heritage. Except for sp 1 itting the 1 arger logs, the logs are unhewn except at the ends, where they have been trimmed before cutting the notches. The easternmost crib is the largest of the two, measuring about 17 feet east-west and 13 feet north-south. The westernmost crib is about 14 feet 8 inches east-west by 13 feet north-south. 
Both cribs rest on corner piers made of stacks of 1 arge ironstone blocks, and both have raised wooden floors. The eastern crib has heavy split-log floor joists, with the split side up, with the ends laid lap-jointed on top of the north and south wal1 sil1s. Alternate joists have pointed or squared-off sawed ends. The floor, of milled lumber, rests on these joists. The floor in the westernmost $c r i b$ is somewhat different and consists of heavy planks about 11-1/2 inches wide and 2 inches thick resting on east-west running joists. Both cribs have (machine-cut?) square nails driven into the wal1 logs, especial1y around the doorway of the eastern crib, where a door was evidently hung. Some wire nails are also present and were presumably added some time after the original construction. The western crib has a milled 1 umber door frame and hinge attached with wire nails. A CPS weather data recording station is now located immediately to the northeast. Abundant debris (ceramics, glass, farm machinery parts) associated with this old farmstead is scattered about, especially to the south, where there is a dense thicket of mesquite and other brush. Most of this tract is covered by Crockett soils or Axtel1 fine sandy loam, with smal1 areas of Mabank 1 oam and Demona loamy fine sand, and Tabor fine sandy loam along the intermittent creek at the east corner.

No new sites were found in this tract, although a smal1 collection of historic sherds was made from the Wolf homestead, and a petrified wood flake, a chert $\mathrm{fl}$ lake, and a cobble core were also recovered, indicating a previous $7 y$ unrecognized prehistoric component for this site. A cluster of ironstone rocks found near the southeast fence 1 ine may be associated in some way with the homestead and is described later under. "Isolated Finds."

Ground cover is somewhat heavier in this tract than in tract 1; visibility was less favorable. Only a few small areas are actively eroding.

Iract 5 ( 38 hectares; 94 acres; estimated $40 \%$ coverage in phase I survey): This tract 1 ies on the east side of Highway 696 and is enclosed on the northeast and southwest by active county roads. Most of it 1 ies on the gently sloping northwest side of an intermittent creek draining north into Willow Creek. This hillside is mostly open, heavily grazed pasture with thin grass cover and good ground visibility. The subsoil is exposed in some places. Agricultural fields, not cultivated at present, are located at the north and south corners; the south field, on the southeast side of the creek, has a $1 \mathrm{ag}$ deposit of chert cobbles on a somewhat deflated cover of Demona loamy fine sand and was shovel tested, but no cultural debris was found. The rest of the tract consists of the creek bottom, which has been partial1y cleared, leaving the larger trees standing. A good many very large oaks are present along the creek; the soil here is Tabor fine sandy loam. At one point the creek has been dammed to create a smal1 1 ake. Most of the tract has Axtel 1 fine sandy loam.

No previous $7 y$ unrecorded sites were found in this tract. An old house and barn (41 BP 203; see Kel1y and Roemer 1981:20; Fig. 6,b) were located at the northwest side of the tract adjacent to the highway, and a modern brick house (the Weisner home) with outbuildings is located to the southeast. A couple of chert flakes were noted near a small stock tank on a gully draining southeast down the hillside, east of the old house, but a careful search did not reveal anything else. Local informants have suggested the Cruse family 
either built this house or were early occupants (personal communication, Mrs. John Casey to Erwin Roemer, Jr., 1980, field notes on file at CAR-UTSA). Wi 11 iam F. Cruse (see the section of this report on Morgan Chapel Cemetery) bought the 100 acres of 1 and comprising tract 2 from C. W. Brooks, of Wil 1 iamson County, in March of 1883, and the 1 and remained in the Cruse family untiT 1925 (except between 1922-1925 when Cruse's son Wi11iam T. first sold it to J. Watson Wolf and then bought it back). The Cruses were probably the first 1 andowners actual1y resident in this tract (a 1 though an ear 1 ier owner, A. M. Brooks, claimed to have "entered upon and taken possession of" the 1 and in 1856 [L. C. Cunningham to A. M. Brooks, deed, August 17, 1870]). Brooks was a prominent Bastrop County 1 andowner who operated a sawmil1 in about 1850 near Sayers (Moore 1977:19). If indeed the first occupancy of this 1 and was in 1883, the house should date no earlier, and in fact its architecture seems to agree with an estimated date of about 1883. A brief revisit during the dismant 1 ing of the house in November 1984, provided a better opportunity to examine its construction. It rests on 1ap-jointed 9inch square hewn $10 \mathrm{~g}$ sills which in turn rest on sawn log piers. The framework is of $2 \times 4$ studs, sawn but not $p 1$ aned 1 ike modern $2 \times 4$ 's, and is nailed together with machine-cut square nails (Fig. 2). At least one of the floor joists is nailed in with a heavy square spike. Exterior and interior wal1s are covered with $1 \times 11$ inch or $1 \times 12$ inch planks. Flooring is tongue and-groove. The chimney is $10 \mathrm{cal}$ yellow brick (painted red) resting on a foundation of large ironstone 5labs. Features such as a gas outlet and asphalt shingle roofing are obvious later additions. The use of cut nails both for framing and finishing suggests the house was built before 1890 , since Fontana et a1. (1962:49-50) report wire nails were very uncommon in the United States before 1879, but rapidly replaced cut nails afterward, especial1y from 1890 to 1895. Milled Tumber would have been available 1 ocal1y much ear 1 ier (the Bastrop Steam Mi11 Company was incorporated in 1838; Webb 1952, Vo1. 1:120). If the fireplace is made of pressed brick, it may be a 1 ater addition since the Elgin Press Brick Company did not begin operation until 1897 (E1gin Historical Committee 1972:34).

Tract 8 (99 hectares; 244 acres; estimated $60 \%$ coverage in phase I): Tract 8 Ties entirely in Lee County, immediately to the northeast of the Bastrop/Lee County line, on both sides of Highway 696 and southwest of Highway 619. It has the highest drainage density and consequently the most abundant wooded areas of any of the tracts examined in phase II. Most of the tract is divided into a series of fields that were in cultivation until recent $1 \mathrm{y}$, bounded by gallery woodlands along the drainages. The tract is bisected by Willow Creek, an eastward-draining perennial stream (Fig. 12,b), and is further partitioned by several intermittent tributaries. The 1 andscape is generally either quite open or heavily wooded, although some areas near the center of the tract have been invaded by dense mesquite thickets, and some of the fields that have been abandoned the longest have fairly heavy grass cover. A few areas are heavily eroded, but most of the tract is not. Al1 of the fields have been disturbed by cultivation. This tract also has the on $7 y$ extensive belts of upland woods seen in the survey.

Three sites (4I LE 73, 41 LE 74, 41 LE 75), one of them prehistoric, were found in this tract. A prehistoric site (4I LE 63) reported by the phase I survey was searched for but could not be relocated. There is considerable evidence of 20th-century occupation in the area south of Willow Creek and 


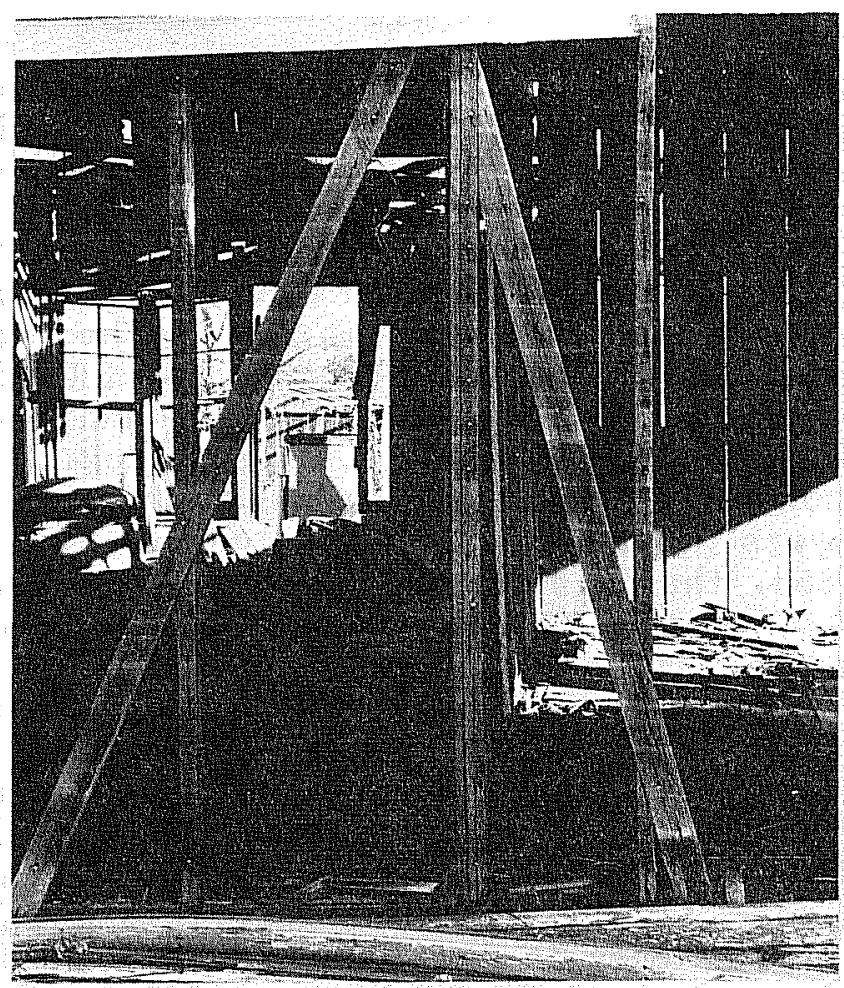

B.

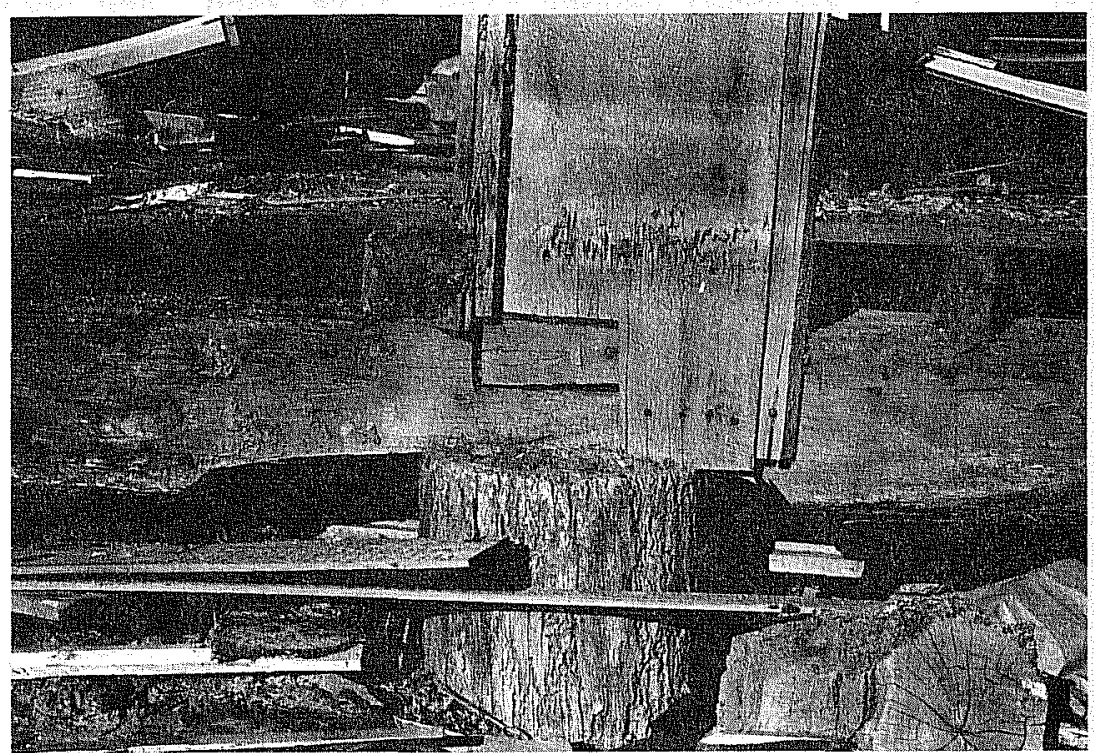

b

Figure 2. The Cruse House (41 BP 203) as it Appeared While Being Dismantled in November 1984. a, looking southeast at part of northwest wa 11; note sawn. but unplaned $2 \times 4$ studs with embedded machine-cut nails, also unusual bracing pattern. One room appears to left of central stud, another to right of it; b, detail of 1ap-jointed, adzed sil1 log at center of southwest wa11; note machine-cut nails. 
north of Highway 696. One of two old tin-roofed barns examined there has a few square nails embedded in the plank siding, suggesting it may have been built of 1 umber salvaged from an older building, but both appear to be of 20th-century construction; abundant contemporary trash is scattered about. Other trash dumps were noted farther to the east. West of the highway intersection is a we 11 and we 11 house made of Butler bricks, and again a good deal of comparatively recent trash can be seen in the area. None of these recent structures or debris scatters were recorded as archaeological sites.

\section{SURVEY AND DOCLMENTARY SEARCH METHODS}

The contract proposal for phase II specified that survey coverage would emphasize wooded areas not thoroughly covered by the phase I survey. However, in practice it proved impossible to enter, much less examine, some of the most densely wooded bottom 1 ands. We found that because of 1 and clearing practices the wooded zones corresponded closely in most cases to the flood zones of the creeks, with topography dominated by branching channels, scoured pools, hummocks and splaylike deposits of mud and sand, and driftwood piles. Out of the immediate flood zone, vegetation density generally lessened, and the margins could be traversed by irregular transects. Infrequent upland woods were generally open enough for negotiating transects; in fact we spent a good deal of time checking the high wooded ridge at the southeast corner of tract 8 (Mauldin survey) because two sites had already been found in analogous topographic situations in tract 19.

Shovel tests were dug in two situations: (1) in vegetated areas near sites that had al ready been recognized from surface debris, in order to better define the 1 imits of the sites; (2) in vegetated areas where no surface debris was visible but where the topographic situation suggested an archaeological site might occur. In general, shovel testing was not heavily emphasized; in nearly al 1 parts of the project area, undisturbed clay subsoil was found at about 30 to $60 \mathrm{~cm}$, and in most areas gopher burrows, tree windthrows, or gullies had brought a sample of the soil profile to the surface. Nearly all the shovel tests we dug were sterile; cultural debris was found on $7 y$ in those tests dug near sites that had already been recognized from surface debris. Shovel tests were not screened.

During the survey, location was determined from a blueline copy of an excellent 1:1000 orthophoto map furnished by CPS, which provided better map coverage than the $7.5^{\prime}$ USGS maps of the area.

Limited documentary research was done on the two historic sites located by the survey. I began by checking the Abstract of Title in the CPS files to try to determine who the earliest resident 1 andowners were in the tracts where historic sites were found. Further data may well 1 ie in the original courthouse records themselves, in Lee and Burleson Counties, but they have not been checked yet. Federal census records (population and agricultural schedules) were checked in the genealogy section of the Texas State Library; the statewide index to the 1850 census was especially useful there. The procedure essentially consisted of checking the censuses for the counties concerned to determine when a 1 andowner 1 isted in the Abstract first appeared on a census as a resident of that county; the precincts cannot be identified, 
nor were the early censuses partitioned by precinct, but since the enumerator 1 isted adjacent households in sequential order, if a pattern of 1 andowners recognizable from the Abstract appears, it is a safe assumption that the area enumerated is the one in question. This technique worked well in tracing 1 and occupancy in tract 8. Holdings of the Barker Texas History Center (University of Texas at Austin) and the Texas State Archives were checked for old maps; the Archives were also consulted for information on William Cruse, a Confederate veteran buried in Morgan Chape1 Cemetery.

\section{THE SITES}

\section{BP 264}

A prehistoric site, 41 BP 264, is located in open pasture on a high sandy ridge at 510 feet MSL and below, toward the southeast end of tract 19. This north-south oriented ridge 1 ies about $240 \mathrm{~m}$ west of a sma 11 , nameless, intermittent creek, a southward-draining first-order tributary of Big Sandy Creek. The crest of the ridge 1 ies about eight meters above the creek bed, which was dry during our field work. The flood zone of the creek is covered with a dense post oak woodland, including some of the thickest vegetation and largest trees seen during the survey. At the margin of the flood zone, southeast of the site and perhaps three or four meters lower in elevation is the smal1 stand of pines mentioned earlier. Most of the cultural debris was found in eroded areas on the eastern flank of the ridge. Basal fragments of a Plainview and a possible Pedernales(?) point, a metate, several manos or mano fragments, a couple of possible hammerstones, some cores, a smal1 collection of chipping debris, and a few fragments of fire-cracked chert and quartzite were found on the surface. The western flank of the ridge has been partly removed by a 1 arge, shal 10 quarry pit about $150 \mathrm{~m}$ by $275 \mathrm{~m}$ across with an average depth of perhaps a meter or more. Here, 20 or 30 years ago the sand, along with part of the archaeological deposits, was removed down to basal clay and sandstone by the Butler Brick Company for use as bricktempering material (Frank Schindler, personal communication). A Clear Fork too 1, two possible uniface rejuvenation flakes, a biface preform failure, and a smal1 amount of scattered chipping debris were found 1 ying around the exposed rim of the basin. Over most of the rest of the ridge, the cover sands have been partially removed, leaving a mantle perhaps $15-20 \mathrm{~cm}$ thick in most areas. Except where erosion has removed this thin mantle down to basal clay, a thick mat of coastal Bermuda grass has been established, substantial1y concealing the ful1 extent of disturbance. The irregular, undulating topography, with closed depressions present in some areas suggests, however, that most of the ridge has been disturbed by quarrying operations, even where the sand cover has not been completely removed. A11 of our test excavations here were directed toward verifying this impression. Only at the north end of the ridge is there an area with what appears to be a complete, undisturbed soil profile; here a relatively flat area on the crest of the ridge is out 1 ined by a low scarp perhaps $60-70 \mathrm{~cm}$ high that appears to represent the $1 \mathrm{imit}$ of sand borrowing operations. Two shovel tests in this area, however, were sterile, suggesting the archaeological deposits never extended this far north (Fig. 3 ). 
This page has been

redacted because it

contains restricted

information. 
The approximate center of the site is marked by a 1 arge sand pile about $16 \mathrm{~m}$ in diameter, a remnant of the sand loading operations; $45 \mathrm{~m}$ southeast of this pile is a low swale forming a closed depression about 9 by $23 \mathrm{~m}$ across and no more than about $30 \mathrm{~cm}$ deep. On our first visit to the site, standing water partiy filled this basin, but had evaporated by the time of our second visit, when several crawdad burrows were visible in the bottom. A single large willow tree stands just to the northwest of the depression, suggesting that it provides a fairly reliable water supply. Frank Schindler was of the opinion this depression was an artifact of the sand quarrying operations, but the size of the willow tree might suggest it predates the quarrying and conceivably might be a natural closed depression fed by a small perched water table. If this is true, it might help explain why a location so high above the nearest drainage was selected for occupation. A shallow shovel test about $9 \mathrm{~m}$ north of the depression encountered only compact, sterile clay.

Figure 4 shows the $64 \mathrm{mcm}$-deep soil profile in shovel test 1 , one of the two shovel tests dug in a sterile but undisturbed area to the north of the site. Presumably it is representative of the soil profile that existed over most of the site before disturbance. Here four distinct units were present: (1) 17$21 \mathrm{~cm}$ of structureless gray brown fine sand; (2) a similar unit, slightly darker and grayer, 19-23 cm thick; (3) a thin zone about $3 \mathrm{~cm}$ thick, of structureless fine sand, 1 ight $\tan$ in color and wetter than the units above; (4) mottled orange sandy basal clay. Units 1-3 are presumably in situ pedogenic units, although the origin of unit 3 in particular is problematica1. Whether unit 2 represents a buried soil is unknown. Visual inspection suggests grain size of the sand is relatively constant throughout the profile, which seems to vary mostly in organic content. Shovel test 2 , located about $50 \mathrm{~m}$ to the north, has similar stratigraphy, but compressed into about $30 \mathrm{~cm}$ of sand overlying the basal clay.

Three 1- $\times 1-m$ test pits were excavated at this site. A11 were dug in $5 \mathrm{~cm}$ arbitrary levels (with modifications noted below), and a 11 were screened through 1/8-inch mesh screen. Because of the smal1 screen size used, much of the test pit collection consists of very smal1 chert flakes not represented in the surface collection, which is biased toward larger flakes. Test pit 1 was 1 ocated about $27 \mathrm{~m}$ east of the 1 arge centra 1 sand pile, test pit 2 was located about $39 \mathrm{~m}$ southwest of the pile, and test pit 3 was located about $45 \mathrm{~m}$ west-southwest of it. A11 of the test pits revealed very thin deposits of sand over basal clay, with very low densities of cultural debris in the sand. Although the test pits did not provide any direct evidence that the remaining sand cover had been disturbed by the machinery, it seems probable that this was the case. Bottle glass fragments were found in the single $5 \mathrm{~cm}$ level removed from test pit 3.

Test pit 1: This unit was p 1 aced about $20 \mathrm{~m}$ west of and ups 10 pe from the eroded area where the metate and the Plainview base were found, and on a somewhat more level part of the slope which looked as if it might retain some intact deposits. Four levels were dug, 0-5, 5-10, 10-13, and 13-23 cm below ground surface at the southwest corner. The third level bottomed out on basa 1 clay in most areas, and level 4 consisted on ly of a smal1 irregular area in the southeast quadrant. The contact with the clay was found to be somewhat abrupt, but irregular and hummocky. A distal biface fragment was 
$41 \mathrm{BP} 264$

SHOVEL TEST I

NORTH WALL

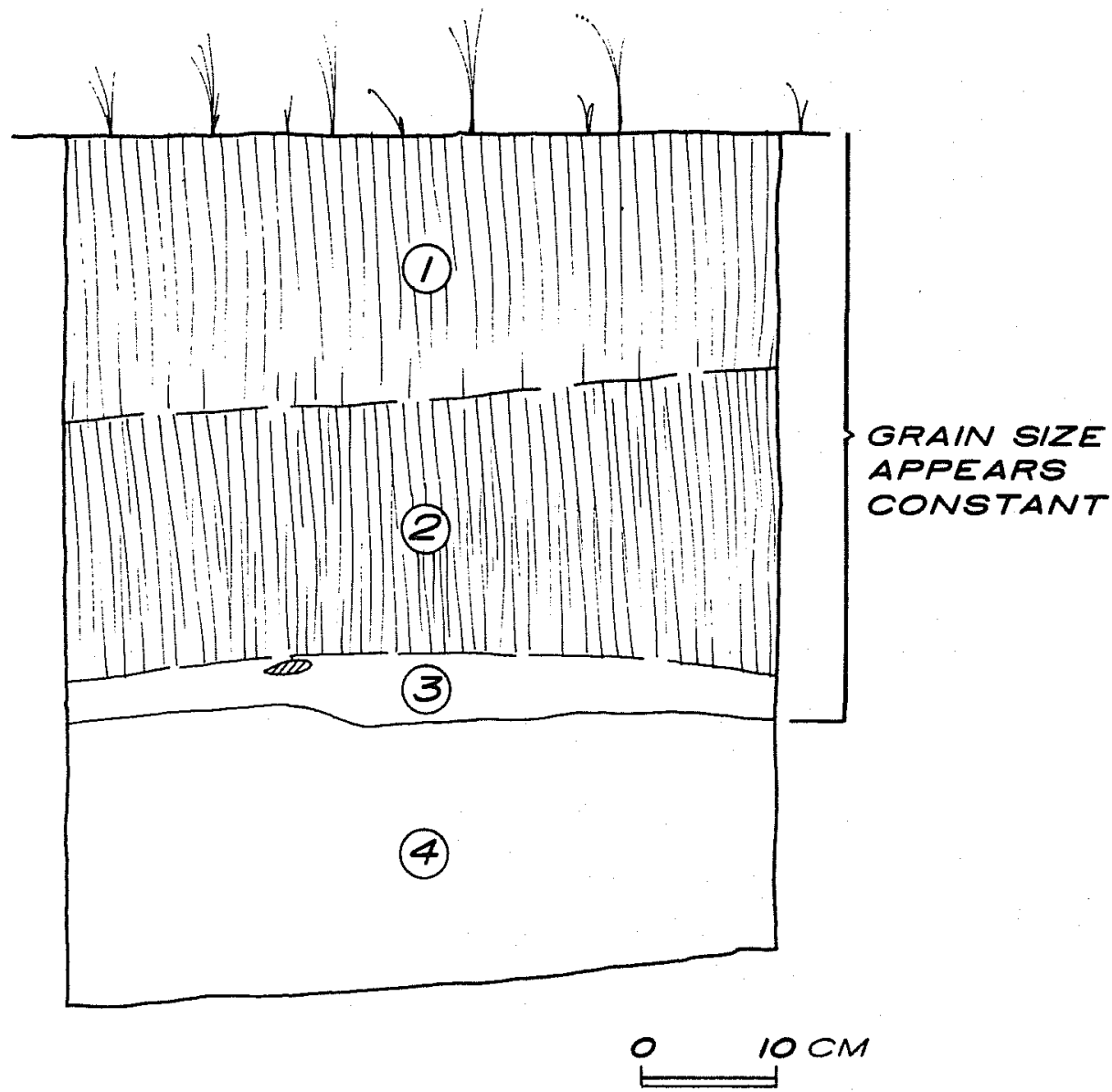

(1) STRUCTURELESS GRAY BROWN (IOYR 5/3.5) FINE SAND WITH ROOTLETS. LOWER CONTACT VERY GRADATIONAL.

(2) SAME AS (1) EXCEPT SLIGHTLY GRAYER AND DARKER WITH FEWER ROOTLETS; 10 YR 5/2.5; LOWER CONTACT GRADATIONAL.

(3) DISTINCT LIGHT (IO YR 6.5/3) TAN STRUCTURELESS FINE SAND, WET; LOWER CONTACT IRREGULAR, CLEAR.

(4) MOTTLED ORANGE (7.5 YR 5/4.5) SANDY CLAY; MOTTLES 2.5 YR 416

Figure 4. Soil Profile in Shovel Test 1 at 41 BP 264. 
found in situ at $12 \mathrm{~cm}$ (Fig. 5,d) and a small chunk of charcoal at $13 \mathrm{~cm}$. See Table 2 for an inventory of debris from the test pits.

Test pit 2: This unit was located about $4.5 \mathrm{~m}$ east of the eastern rim of the exposed sand pit, about $10 \mathrm{~m}$ north of the south boundary fence 1 ine for tract 19. The exposure in the rim of the sand pit did not suggest the deposits there had much depth, but a significant amount of chipping debris was noted eroding from the rim, so this test pit was dug mainly to assess the density of cultural debris. Three levels (0-5, 5-10, and 10-16 cm) were dug; again, as in test pit 1, the clay contact sloped eastward, although in this pit the transition from sand to basal clay was more gradational. Very 1 ittle material was recovered: a few smal1 flakes, some smal1 fragments of firecracked quartzite or petrified wood, and a bottle glass sherd, the latter in level 1.

Test pit 3: This unit was located about $3 \mathrm{~m}$ north of the north rim of the sand pit and consisted only of a single $5 \mathrm{~cm}$ leve1; at $5 \mathrm{~cm}$ the fill graded into compact orange basal clay, with some sandstone bedrock showing in the southeast corner. A sma11 dista 1 biface fragment, a core remnant, a meta 1 fragment, and some bottle glass sherds were recovered from the screen.

\section{Artifacts}

Plainview basal fragment ( $\left.F i g, 5, a, a^{\prime}\right)$ : This basal fragment is made of 1 ight gray brown vitreous chert. It is essentially straight-sided, expanding very slightly toward the distal end. The base is deep $7 y$ concave, more so than in most Plainview points, although the depth of the basal concavity, at $3.22 \mathrm{~mm}$, is well within the range of examples from the Plainview site (see knudson 1983:Table 9, "proxima1 contour depth"). The point has been broken not by a simple transverse snap but by a percussion blow directed at one edge (the right edge in Fig. 5,a) disposed 1 ateral1y and s1ightly towards the base. Speculatively, this might represent a failed attempt to establish a platform for reworking a specimen that was already broken but somewhat longer. This is simply conjectural, but the type of break seen here is certainly uncommon (see Knudson 1983:Tab1e 10). There is 1ittle evidence of damage to the edge following breakage; except for one area with a patterned series $2.0 \mathrm{~mm} 1 \mathrm{ong}$ of unifacial flake scars extending $0.4 \mathrm{~mm}$ back from the edge, damage consists only of mostly random smal1 nicks or invasive scars distributed bifacially.

The point has been shaped with 1 arge, shal1ow, presumably soft-hammer percussion scars that in a 11 cases seem to overreach the midline of the point, generally extending about two-thirds of the way to the opposite edge. The 1 argest of these surviving scars is at least $1.28 \mathrm{~cm}$ wide and nearly as long, although the termination is indistinct. Superimposed on the thinning scars are smal ler edge-trimming pressure flake scars. These are not very numerous and are bifacially distributed but seem to be concentrated on one edge on one face and on the opposite edge on the opposite face, as if the craftsman had turned the specimen over while trimming the edge. The edgetrimming scars vary from expanding to long and narrow in shape and are general1y about 2.5 to $4.5 \mathrm{~mm}$ long and about 1.0 to $3.0 \mathrm{~mm}$ wide. This specimen seems to correspond approximately to Knudson's variety II bifaces, a though there seems to be $1 \mathrm{ittle}$ evidence of pressure retouch by comparison. 
Certainly this specimen differs from the parallel or collaterally flaked variety III points (Knudson 1983:24-25).

Edge grinding covers both edges al1 the way to the break, and is present on both basal ears and on a smal1 remnant area near the center of the basa 1 edge. One basal ear consists of a small facet retaining the original cortex, and an even smaller remnant of white cortex is visible on the other ear, suggesting the point may have been made from a blade whose distal termination consisted of natural1y faceted cortex from the base of the blade core.

$\begin{array}{lr}\text { maximum length: } & 26.88 \mathrm{~mm} \\ \text { width at base: } & 17.74 \mathrm{~mm} \\ \text { width at break: } & 19.46 \mathrm{~mm} \\ \text { maximum thickness: } & 6.76 \mathrm{~mm} \\ \text { depth of basal concavity: } & 3.22 \mathrm{~mm}\end{array}$

length of ground proximal edges:

unknown $(26.34 \mathrm{~mm}$ or more on one edge, $24.98 \mathrm{~mm}$ or more on the other)

Provenience: Surface, in eroded area near eastern edge of site (see Fig. 3 ).

Pedernales(?) basal fragment ( $F i g .5, b)$ : This specimen is tentatively regarded as the stem portion of a Pedernales point, although with the blade element missing, classification is uncertain. Made of 7 ight yellowish brown chert, it has a deeply concave base. One basal ear is sharply pointed while the other has been snapped off. The edges of the transverse snap show no further damage after breakage of the specimen. Lateral and basal edges show no evidence of grinding. The specimen seems to have been produced by soft hammer percussion followed by minimal pressure retouch.
maximum length:
$19.88 \mathrm{~mm}$
maximum width:
$17.78 \mathrm{~mm}$
maximum thickness:
$5.70 \mathrm{~mm}$

Provenience: Surface, near Plainview point (see Fig. 2).

Clear Fork tool (Fig. 5,c, $C^{\prime}$ ): This bifacial specimen is made of 1 ight gray brown, grainy, rather poor quality chert and has a steep, asymmetrical bit that appears to have been resharpened repeatedly until the working edge angle increased to a nearly nonfunctional state. The tool is triangular in out 1 ine with a somewhat pointed proximal end and is thickly lenticular in cross section. It appears to have been made by hard-hammer percussion. At $20 x$ magnification, light to moderate edge rounding, with some polish appears on both 1 ateral edges, both in reentrants and on edge projections. It seems to be somewhat more common toward the distal end. Moderate to heavy rounding and polish is apparent on one 1 ateral edge near the distal end. Some rounding and polish also occur on the ventral surface near the distal corners. At $20 x$ the central part of the working edge appears unmodified except for crushing and step fracturing produced by the most recent attempt to rejuvenate the edge. Some flake scar ridge polish is visible on both dorsal and ventral surfaces, mainly toward the proximal end, but is not well developed and is noticeable only on the ventral face. 
Figure 5. Prehistoric Artifacts from $41 \mathrm{BP} 264$. A11 found on the surface except $d$ and $e$.

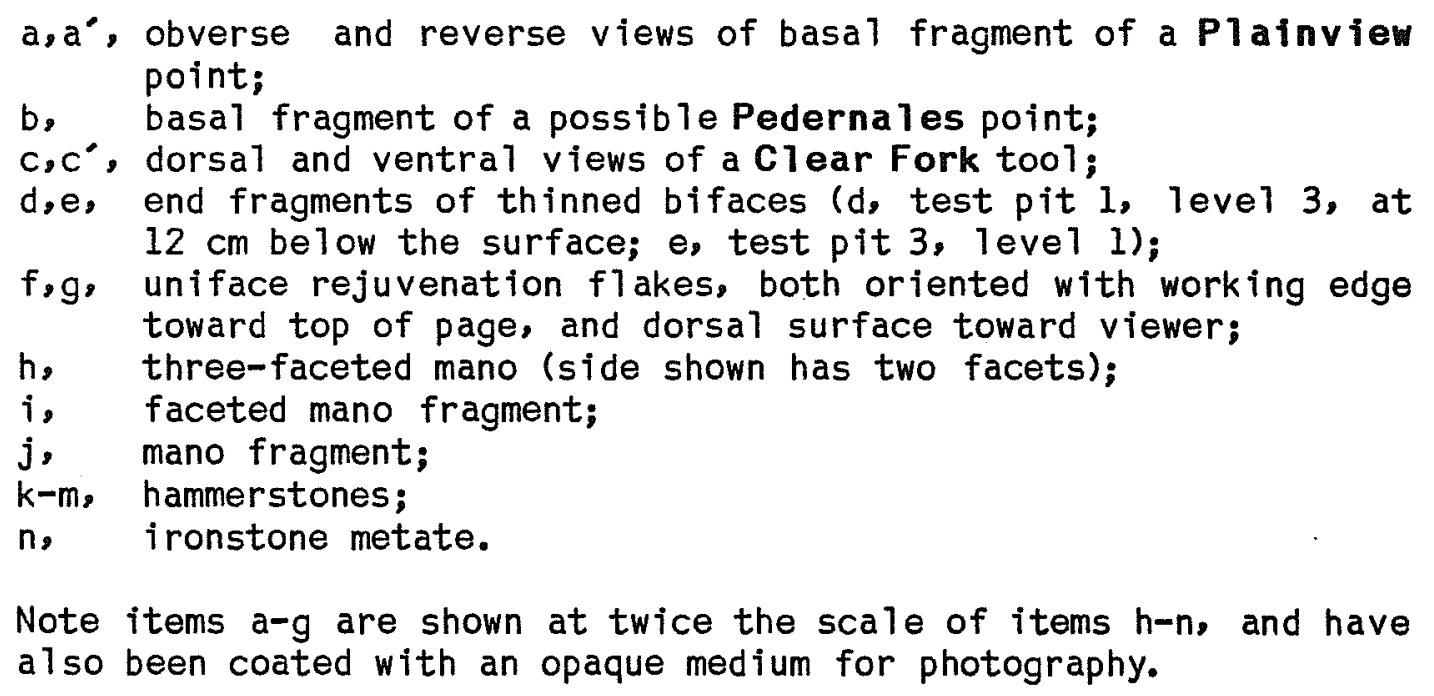

Note items $a-g$ are shown at twice the scale of items $h-n$, and have also been coated with an opaque medium for photography. 

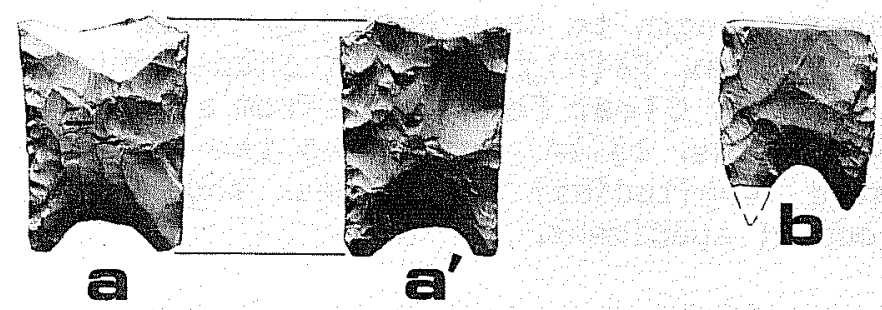

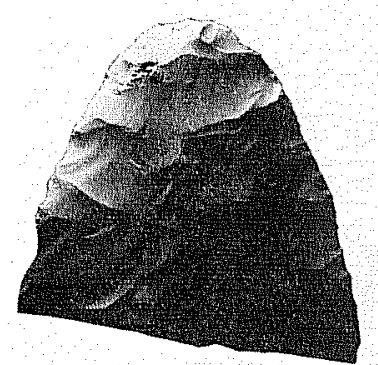

d
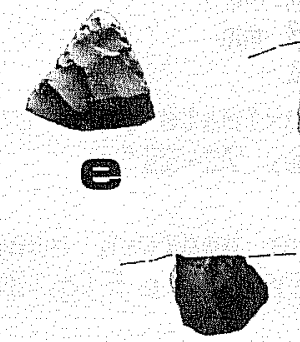

g
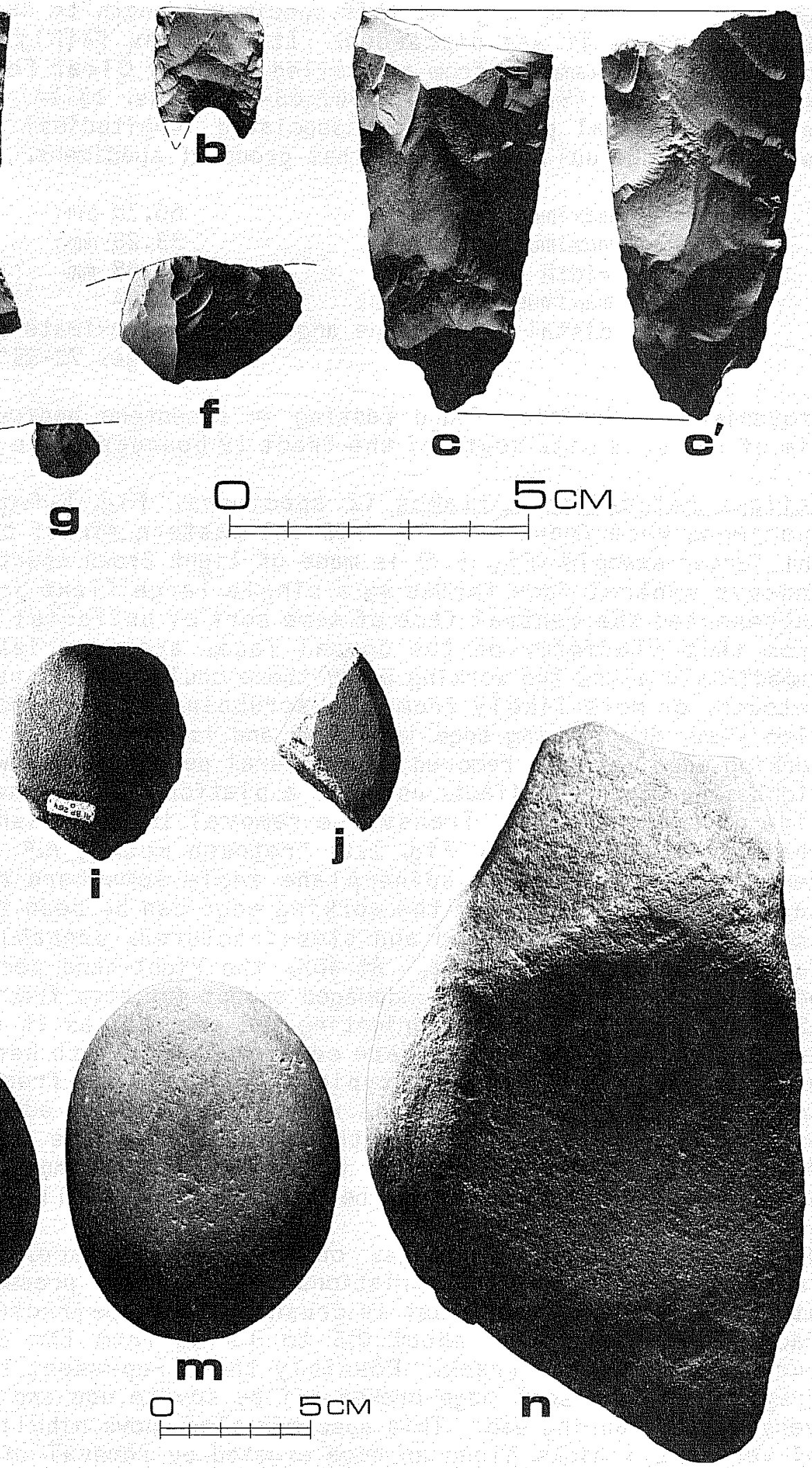
Comment: The working edge of this specimen appears to have been rejuvenated shortly before it was discarded. It compares fairly well in shape and condition with examples from a detailed study of Clear Fork tools from a site in Choke Canyon (Brown et a 1. 1982:65-74, Figs. 13,14) but 1 acks the more extensive ventral polish, with associated longitudinal striations, and the deliberate edge dulling seen on that group of specimens.

$\begin{array}{ll}\text { maximum length } & 66.70 \mathrm{~mm} \\ \text { maximum width: } & 33.28 \mathrm{~mm} \\ \text { width at bit: } & 32.68 \mathrm{~mm} \\ \text { maximum thickness: } & 18.04 \\ \text { distal spine-plane angle: } & \text { approximate mean ca. } 75^{\circ} \text {; } \\ & \text { range, } 72-93^{\circ}\end{array}$

Provenience: Surface; found resting on sandstone bedrock near the eastern rim of the sand pit, south of the tract 19 boundary (see Fig. 3 ).

Uniface rejuvenation flakes (2 specimens, Fig. 5,f,g): Both of these specimens were found eroding from the eastern rim of the sand quarry pit. The larger example (Fig. 5,f) is made of 1 ight brown chert and has a markedly concave ventral face formed by a single large flake scar that presumably represented the ventral face of some sort of unifacial tool. Originating from this platform, on the dorsal face, are a series of smaller scars immediately along the working edge; these could be from use retouch, pressure retouch, or more 7 ikely from edge scrubbing with a percussor. In overa 11 plan view, the working edge is convex and is $25 \mathrm{~mm}$ wide. This section of the working edge has been removed by a lateral percussion blow delivered from the right side of the artifact, using as a platform an intersecting facet on that side of the artifact. Transverse removal in this fashion corresponds to Shafer's (1970:481-484, Fig. 1,a) "retouch method A." The edge that was removed has an average spine-plane angle somewhere around $57^{\circ}$. At $20 \mathrm{x}$ magnification and above, the working edge can be seen to vary from fairly acute to somewhat crushed and step-fractured, probably from use, and is fairly jagged in some areas. At 40x, the right-hand portion of the working edge appears substantially undamaged except for step fracturing, but the 1 ast $12 \mathrm{~mm}$ of edge to the left (orienting the artifact as it would have appeared in use) shows 1 ight to moderate edge rounding, with heavy rounding on one edge projection. This is a typical wear pattern frequently seen on end scrapers, adzes, and other tools with distal working edges; the central part of the working edge suffers the most severe use and is consequently resharpened more frequently, so that the heaviest 1ong-term accumulation of use wear shows on the distal corners, which are actually less heavily used.

Near the center of the edge, on the ventral face, a series of short, irregular, poorly defined striations appears to be present. These originate at the edge, in an area that is crushed and step-fractured on the ventra 1 face, and extend back about 0.3 to $0.5 \mathrm{~mm}$ from the edge, often with a curving, irregular track. Possibly these represent the tracks of sma 11 fragments of the tool edge broken off by severe use and dragged against the ventral face during use. This specimen also shows nibbling and an assortment of very small nicks along an edge created by removal of the flake from the parent tool, indicating that this rejuvenation flake was also used as an expedient scraping tool after its removal. 
The second specimen ( $F$ ig. $5, g$ ) is a very smal1 section of a unifacial1y retouched edge $8.5 \mathrm{~mm}$ long, made of white chert. Unlike the first specimen, it is simply a smal1 shatter fragment without a bulb of percussion present to indicate the type of remova 1. At $40 \mathrm{x}$ magnification, there is 1 itt 1 e or no evidence of edge rounding, but the ventral face is step-fractured, and there are some very smal1 step fractures on the dorsal face as we11, extending up to $1.3 \mathrm{~mm}$ back from the edge. No striations are visible on the ventral face.

Comment: Both of these specimens are presumed to indicate on-site refurbishing of unifacial scraping tools, although in the first instance there is also 1 imited evidence of use of the detached edge section itself as an expedient scraping tool. The type of tool represented is unknown, but it might be an end scraper made on a large flake.

Provenience: Surface, east rim of sand pit (both specimens).

Distal or proximal biface fragments (2 specimens, Fig. 5,d,e): Both of these specimens were found in test pits. One (Fig. 5,d) is a 1 arge, wel1-thinned fragment of black chert with a rounded end and a transverse snap, and was made by soft-hammer percussion; it may be a preform failure. The maximum measurable width/thickness ratio is 5.28:1. At 40X, moderate edge rounding is visible on both edges, essentially confined to edge projections; reentrant portions of the edge appear most $7 y$ pristine. This edge rounding probably represents remnants of platform preparation associated with thinning of the biface.

The other specimen (Fig. 5,e) appears to be the distal end of a finished artifact, perhaps a dart point, and is made of 1 ight brown chert; it also has a transverse snap. At 40X, 1 ight to moderate edge rounding is visible on both edges, especially at the tip, probably indicating some use of the specimen as a cutting tool.

Provenience: Test pit 1, level 3 (in situ at $12 \mathrm{~cm}$ below the surface); test pit 3, leve1 1.

Metate (Fig. 5,n): A large, thick slab of ironstone (ferruginous sandstone) $27 \times 15 \times 7.5 \mathrm{~cm}$ across, with a single concave oval grinding area $12 \times 13 \mathrm{~cm}$ across and about a centimeter deep. This specimen was found on the surface near the eastern edge of the site ( $F i g .3$ ). Weighing $4.8 \mathrm{~kg}$, it is too heavy to be easily portab $1 e$.

Manos ( 3 specimens, Fig. $5, h-j$ ): One specimen ( $F i g .5, h$ ) is an oval cobble of wel1 indurated sandstone $11 \times 8 \times 2.8 \mathrm{~cm}$ in size with a single $\mathrm{flat}$ grinding surface on one side, and two facets intersecting to form a ridge on the opposite side. An irregular spall has been detached from the single facet by a blow to the edge, and the opposite side has two smaller damaged areas. This specimen was found near the crest of the ridge, just northeast of the central sand pile.

Another fragmentary specimen ( $F i g .5, i$ ) is made of ferruginous sandstone similar to the metate, and is actual1y a large spal1 bearing parts of two intersecting facets; it may be part of a ridged mano similar to the first specimen. 
A third specimen, al so fragmentary (Fig. $5, j$ ) is made of pink quartzite and has a flat facet on one side and a convex or flat facet on the opposite side. It was found just north of the central sand pile.

Provenience: Surface (a11 three specimenș).

Hammerstones (2 specimens, Fig. 5,k,1): One specimen is a sma11, round, flattened pebble of very well indurated sandstone $6.8 \times 5.6 \times 3.6 \mathrm{~cm}$ in size and weighing $205.6 \mathrm{~g}$. It shows evidence of battering nearly a 11 the way around its circumference, especially on one side where a facet about $2.3 \mathrm{~cm}$ wide has been created by deterioration of the edge. It has two opposing somewhat flatter sides that are quite smooth in the center, and it is possible this specimen may also have been used as a smal1 grinding stone (Fig. 5,k). It was found east-southeast of the central sand pile.

Another specimen (Fig. 5,1) is a smal1 flattened cobble of fine-grained, very wel 1 indurated ferruginous sandstone, also with two opposing very smooth sides, but no visible faceting. It shows evidence of battering at the two opposing ends and has small areas of peck marks on one side at each end. It is $8.8 \times 6.5 \times 3.6 \mathrm{~cm}$ in size and weighs $293.1 \mathrm{~g}$. Like the first specimen. it might also have been used as a small grinding stone.

Provenience: Surface (both specimens).

Possible hammerstone/grinding stone (Fig. 5,m): A flattened quartzite cobble $12 \times 9.1 \times 3.7 \mathrm{~cm}$ in size, weighing $596.0 \mathrm{~g}$; this item has no definite evidence of human alteration, but appears to have small areas with very faint peck marks on the two opposing ends. The two flat sides are smooth.

Provenience: Surface.

Cores (5 specimens): One specimen is a large cobble $12.8 \mathrm{~cm}$ long of grainy, poor quality chert that has been bifacially flaked in circumferential fashion and shows some evidence of heat damage, probably before flaking. Two other specimens are a small chert cobble and a chert pebble that have been bifacially flaked on one end. A fourth specimen is a quartzite cobble that has been unifacially flaked on one end using a cortex-covered flat side as a platform; judging from the exposed rock, it yielded no usable flakes. The fifth specimen is a sma 11 chert pebble core remnant $3.25 \mathrm{~cm}$ long that has several small flakes circumferentially removed from a single facet prepared platform.

Provenience: The fifth specimen was found in test pit 3, level 1; al 1 others were found on the surface.

Biface reject (1 specimen): A single biface reject made of 1 ight gray brown chert was recovered. It is crudely flaked by hard-hammer percussion, and is $5.3 \times 4.7 \times 1.6 \mathrm{~cm}$ in size. Presumably it was discarded because of failure to thin the artifact.

Provenience: Surface, eastern rim of sand pit. 


\section{Chipping Debris}

The collections from the surface and from the test pits will be described separately to provide an opportunity to evaluate how well the two collection methods have sampled the universe of chipping debris at the site.

\section{Surface Collection ( 86 specimens)}

The surface collection overwhelmingly represents hard-hammer freehand percussion of chert cobbles. No petrified wood is represented, and only one small irregular shatter fragment of quartzite is present. Except for flake fragments, the largest class of chipping debris is secondary cortex flakes, mostly of medium size. The 1 argest of these is about $5 \mathrm{~cm}$ long. The collection represents chiefly earlier stages in the reduction of chert cobbles. No good examples of biface thinning flakes are present, except perhaps two flakes possibly representing intermediate stages in thinning. Some very small flakes may have been produced incidental to trimming either of cores or of tools. While a few direct impact percussion flakes seem to be present, no definite bipolar chipping debris was noted. Debris classes and average weights are given in Table 1.

TABLE 1. SURFACE CHIPPING DEBRIS, 41 BP 264

$\begin{array}{lcc} & \text { Erequency } & \text { Average weight }(g)^{*} \\ \text { primary flakes } & 2 & 7.25 \\ \text { secondary flakes } & 26 & 7.57 \\ \text { interior flakes } & 19 & 2.97 \\ \text { fragments } & 30 & 1.57 \\ \text { chunks, shatter, split } & 9 & 5.92 \\ \quad \text { pebbles } & - & \end{array}$

* Total weight in class divided by number of specimens.

In this report, primary $f l$ akes or $f l a k e$ fragments are those with dorsal surfaces completely covered.with cortex; secondary flakes or fragments have partial cortex; and interior flakes or fragments have no cortex, either on the dorsal surface or the striking platform remnant.

Test Pits (16 specimens)

Chipping debris recovered from the 1/8-inch mesh screen represents most 1 y very sma 11 flakes, including a coup 1 e on 7 y 5-6 mm 1ong, and distal fragments of $\mathrm{f} l$ akes. The sample is too sma 11 for meaningful description. Debris classes and average weights are given in Table 2. 
TABLE 2. EXCAVATED CHIPPING DEBRIS, 41 BP 264

$\begin{array}{lcc} & \text { Frequency } & \text { Average weight }(g) \\ \text { primary flakes } & 0 & - \\ \text { secondary flakes } & 0 & - \\ \text { interior flakes } & 4 & 0.20 \\ \text { fragments } & 10 & 0.67 \\ \text { chunks, shatter } & 2 & 9.05 \\ & - & \end{array}$

\section{Other Artifacts}

Other items recovered from the surface and/or test pits include sections of fire-cracked chert and quartzite cobbles, as well as smaller thermal spalls; a single smal1 chunk of charcoal found in situ $13 \mathrm{~cm}$ below the ground surface in test pit $1 ;$ and some bottle glass and metal fragments, apparently of recent vintage, found in test pits 2 and 3.

\section{Conclusions and Recommendations for 41 BP 264}

The original size of this site is difficult to estimate because of extensive disturbance from sand quarrying operations. We can provide only the roughest guess as to what might have been the maximum dimensions, possibly something on the order of $150 \mathrm{~m}$ east-west by $110 \mathrm{~m}$ north-south. An estimated $25 \%$ of the area has been removed entirely by the sand pit in the southwest quadrant of the site, and apparently all of the rest has suffered severe disturbance, with half or more of the cover sands having been removed. In all three of the test pits, the sand deposits were found to be very shallow (the most extreme case was test pit 3, where on 1 y $5 \mathrm{~cm}$ of sand was 1eft). The off-site shove 1 tests suggest the original depth of the sand may have been about $40 \mathrm{~cm}$. Examination of the area around the site shows no additional material on the surface, except for a few flakes noted on the far south end of the ridge by Marlene Syverson, wel1 outside the tract 19 boundaries.

The Plainview point fragment and the Clear Fork tool suggest one or more early prehistoric components may have been present. Also notable are the relatively large number of grinding stones, the uniface rejuvenation flakes, and the position of the site on a high ridge a significant distance from the nearest drainage, but close to what might have been a natural seep fed by a sma 11, local1y perched water table.

Because no intact archaeological deposits appear to remain at this site, and because very low densities of cultural debris appeared in the test pits, no further work is recommended. 


\section{BP 265}

A sma 11 prehistoric site, 41 BP 265, consists on 1 y of a 1 ight scatter of debris atop a high sandy ridge at the northwest end of tract 19, $60 \mathrm{~m}$ southeast of Highway 696. The site 1 ies at 530 feet MSL and above, with most of the surrounding terrain covered by coastal Bermuda pasture. The nearest drainage is the head of a sma $11 \mathrm{draw} 400 \mathrm{~m}$ to the south: it is intermittent in discharge but retains water where dammed for stock tanks. This part of tract 19 has also been quarried for sand in past years, although some apparently undisturbed areas remain as sma 11 "islands" elevated perhaps a meter or so above the excavated parts. Post oak stands mark these is 1 ands at the north end of the site, suggesting they were left undisturbed because of the trees. A shovel test dug in the post oak grove north of the site yielded no cultural debris from $35 \mathrm{~cm}$ of sand over basal clay. Another shovel test in a treeless remnant at the south end of the site yielded only a small chert cobble core and a fire-cracked quartzite cobble from $30 \mathrm{~cm}$ of sand over basal clay.

Most of the cultural debris was found lying on exposed basal clay in an excavated area about $31 \mathrm{~m}$ long (north-south) by $13 \mathrm{~m}$ wide (east-west, estimated by pacingl. The surface collection consists of one chert cobble core (part of a quartered cobble with several $f 1$ akes removed from one facet), two chert heavy percussion flakes (secondary cortex flakes with broad platforms and prominent bulbs of percussion), three chert flake fragments, a quartzite heat spa 17, an unmodified(?) chert cobble, and one split, otherwise unmodified quartzite pebble.

The survey crew dug two unscreened shovel tests, photographed the site, made a paced sketch map, and made the smal1 surface collection. No further work is recommended at this site.

\section{LE 73}

Site 41 LE 73 has both prehistoric and historic components, and while the two cover somewhat different areas, there is probably enough spatial overlap to justify assigning a single site number as has been done here.

The site is located in tract 8 on the north and northwest flanks of a high hill which crests at about 530 feet (Fig. 6), although archaeological debris seems to be confined to 490-510 feet in elevation. Whi le the crest of the hil 1 is wooded, its north flank is exposed by a recently abandoned peanut field. Some effort has been made to control erosion with contoured agricultural terraces, but most of the topsoil in the field has simply shifted down slope to collect behind the terraces. More recently the terraces have been breached by a 1 arge, centra 1, northward draining gu $17 y$ system that has cut into the basal clay, and in which most of the prehistoric debris was exposed (Fig. 8). Three shovel tests were dug in this field; the first, near the edge of the field in a flatter area 1 itt le affected by erosion, penetrated about $60 \mathrm{~cm}$ of sandy loam before reaching basal clay; the second, in an eroded area, had on 1 y $7 \mathrm{~cm}$ of sandy 1 oam; the third was just upslope of an agricultural terrace and has $68 \mathrm{~cm}$ of sandy loam over a gradational change to basal clay. The contrast between shovel tests 2 and 3 
gives some idea of the amount of topsoil displacement that has occurred since cultivation of this hillside was begun.

At the foot of the hi11, on the west side, a sma 11 intermittent drainage flows northward to join Willow Creek on the north side of Highway 696 . A1though this drainage 1 ies on $1 y$ about $80 \mathrm{~m}$ down slope from the western edge of the prehistoric component, the nearest permanent water (except for a stock pond at the west edge of the field) is $300 \mathrm{~m}$ to the north in Willow Creek, under current climatic conditions. The flood zone of the intermittent creek is heavily wooded and has a dense, tangled understory. Cutting across the creek northwest of the site is the fence 1 ine representing the southwestern boundary of tract 8 , and the Bastrop/Lee County 1 ine as we 11.

\section{Prehistoric Component}

Most of the prehistoric cultural debris found at 41 LE 73 was exposed in and around the large gul1y cutting down the north face of the hil1side. Here, over a distance of perhaps 50 to $80 \mathrm{~m}$, a 1 ight scatter of chipping debris and fire-cracked rock was found. A smaller scatter of debris, including a Scallorn point, was found in a dirt road skirting the stock tank to the west. Shove 1 tests 2 and 3 were dug between these two surface scatters, but nothing was found in either test. The surface evidence, then, suggests the cultural debris is restricted to two separate areas, but since both of these are simply areas experiencing active erosion, it might we 11 be the case that further investigation would show the debris occurs in the intervening area, and perhaps beyond as we 11. The area of the site is unknown, but a rough estimate of the maximum size is approximately $80 \mathrm{~m}$ north-south by $100 \mathrm{~m}$ eastwest. Debris seems to be restricted to 490-510 feet elevation. The top of the hil1 was examined careful1y, but no prehistoric artifacts were found.

\section{Prehistoric Artifacts}

Scallern point (Fig. 10,d): This arrow point is made of gray brown chert, with an expanding stem and straight base that is nearly as wide as the shoulders. The distal end has been removed by a hinge fracture, presumably an impact fracture. At 40X, the edges appear pristine, with no visible use wear. This point corresponds to Jelks' sattler variety (Je1ks 1962:30, Fig. 13, s-u).

$\begin{array}{lr}\text { maximum length: } & 24.84 \mathrm{~mm} \text { (incomplete) } \\ \text { width at shoulders: } & 14.66 \mathrm{~mm} \\ \text { width at base: } & 12.24 \mathrm{~mm} \\ \text { stem width: } & 6.54 \mathrm{~mm} \\ \text { stem length: } & 7.98 \mathrm{~mm} \\ \text { maximum thickness: } & 4.36 \mathrm{~mm}\end{array}$

Provenience: Surface, in dirt road east of stock tank.

Proximal biface fragment ( $F$ ig. $10, e$ ): This artifact is the proximal part of a thinned biface with a straight base and straight to slightly convex sides that expand slightly toward the presumed midpoint of the biface, then begin 


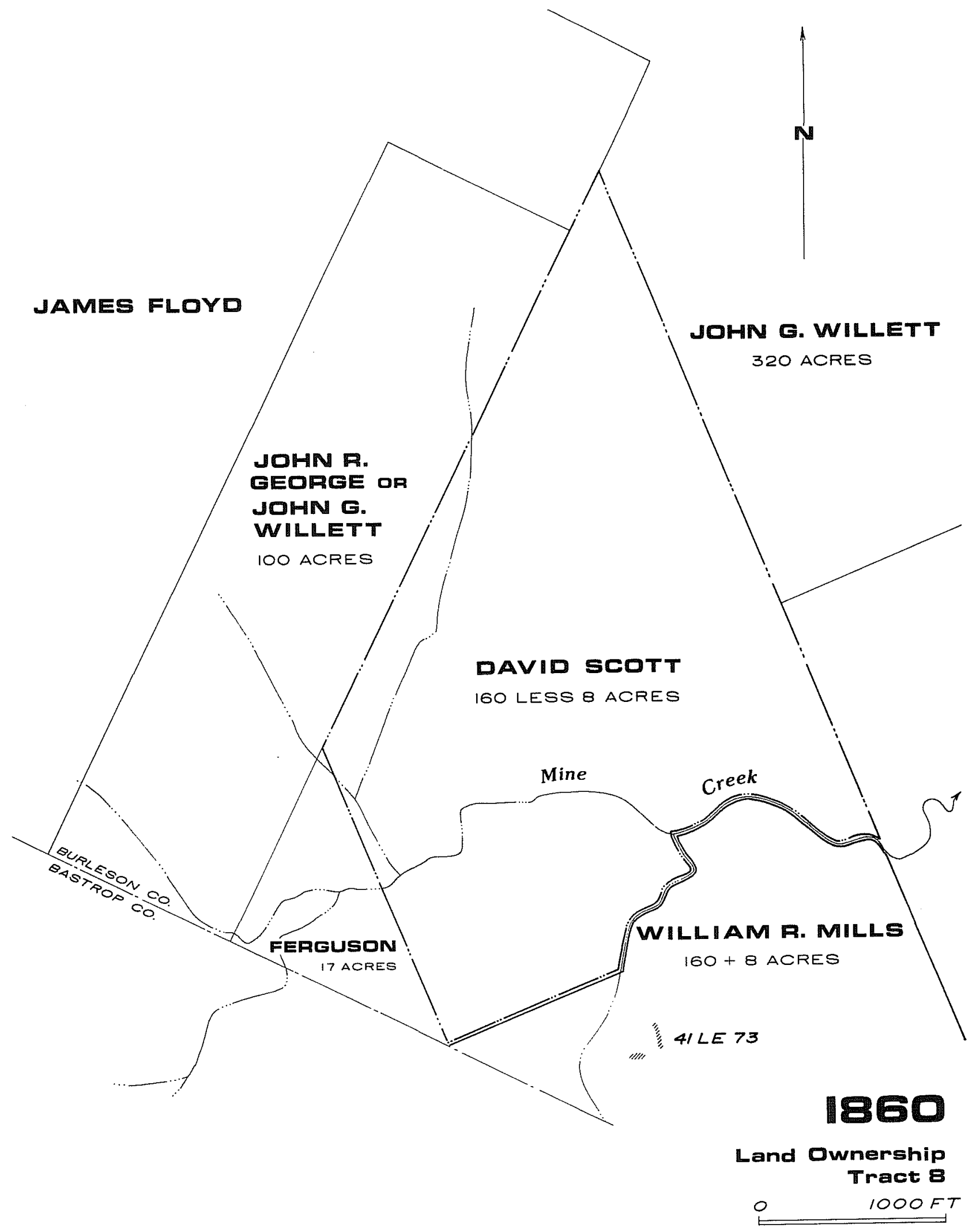

Figure 6. Ownership in 1860 of Land Comprising Tract 8. The Mil1s homestead or trash dump (4I LE 73) is also shown. Ownership of the 100 acres along the southeast side of Floyd's land is ambiguous; either Willett or George might have had possession in 1860 . 


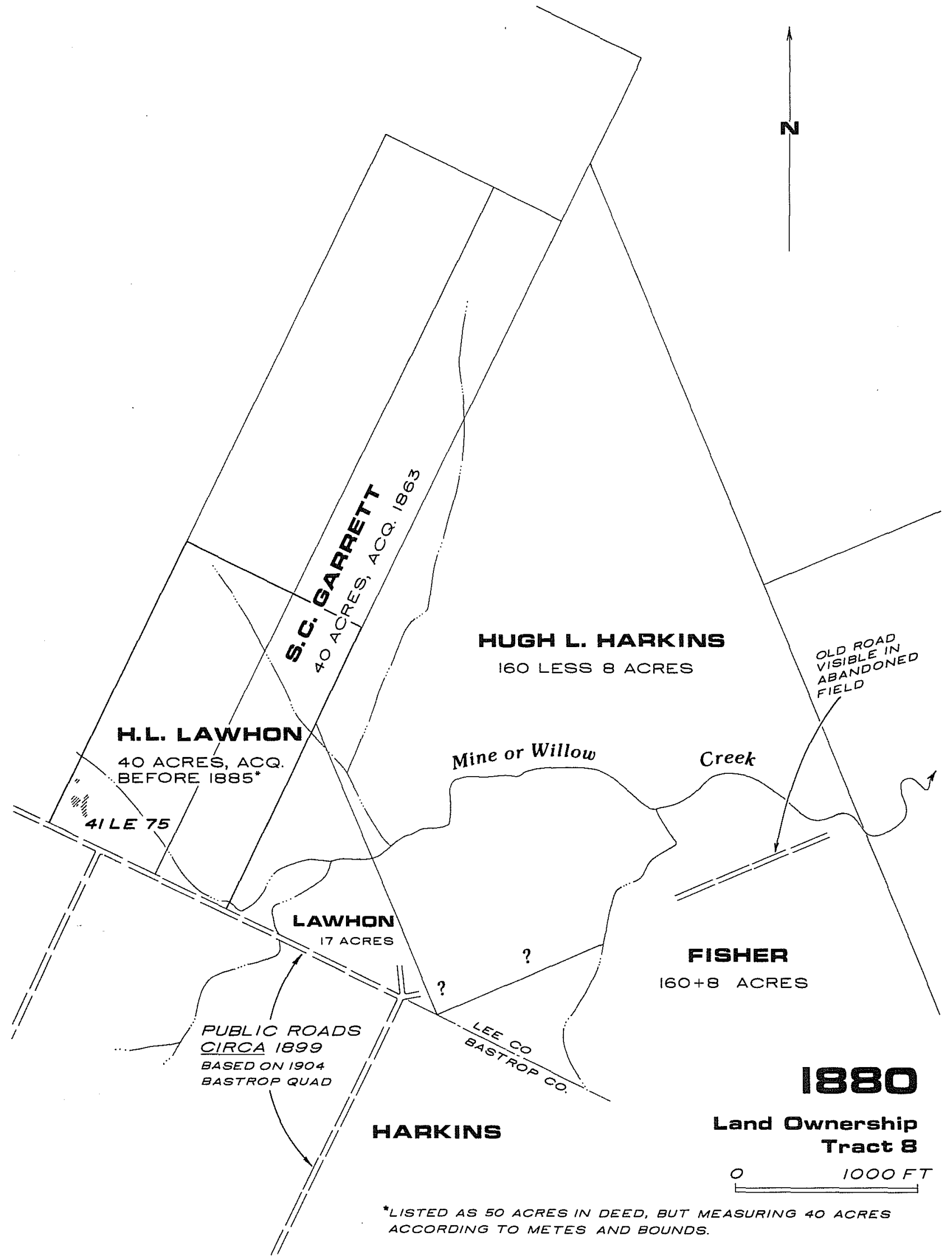

Figure 7. Ownership in 1880 of Land Comprising Tract 8. Note ownership of 1 and containing 41 LE 75 is ambiguous; dates of acquisition are 1 isted on map. The road network shown is taken from an 1899 map, but presumably was in p 7 ace by 1880. Other roads were also present, but could not be accurately projected onto this map. 
This page has been

redacted because it

contains restricted

information. 
to constrict again just below the break. The distal end has been removed by a curving, ob 7 ique snap. The biface has first been thinned, probably by soft-hammer percussion, then somewhat irregularly beveled, apparent 1 y by pressure flaking, on opposite faces. It is made of fine-grained, grayish brown chert. At $40 x$, the edges appear essentially pristine except for considerable smal1-scale step fracturing and crushing resulting from attempts to trim the edge. The snapped edge also appears essentially undamaged.

$\begin{array}{lr}\text { maximum length } & 48.72 \mathrm{~mm} \\ \text { width at base: } & 21.84 \mathrm{~mm} \\ \text { maximum width: } & 31.10 \mathrm{~mm} \\ \text { maximum thickness: } & 6.72 \mathrm{~mm}\end{array}$

Provenience: Central gully system.

Possible modified flakes (2 specimens): Both of these specimens are large soft-hammer thinning flakes, both with rust stains and unifacial nibbling from plow contact. The larger specimen has a small section near the distal end with light edge rounding and polishing visible at magnifications of $20 \mathrm{X}$ and above; it is unclear whether this is natural or represents use as an expedient cutting too 1. The smaller specimen appears to have come from a heat-treated core, and has one area of unifacial nibbling and a deep bifacial notch, both of which may be due to plow contact.

Provenience: Surface, in central gully system.

Cores (2 specimens): A coarse-grained quartzite cobble with several cortexplatformed heavy percussion flakes removed, probably representing a tested cobble, and a smal1 chert core remnant were both found in the central gul1y system.

Possible mano fragment (? - 1 specimen): A smal1 fragment of a quartzite cobble with a convex smooth surface was also found in the central gul1y.

Chipping debris (26 specimens): The smal1 sample of chipping debris is predominantly chert but includes two quartzite flakes and one chalcedony(?) flake. Heavy percussion flakes are chiefly represented but several softhammer thinning flakes are present. Debris classes and average weights are given in Table 3.

TABLE 3. SURFACE CHIPPING DEBRIS, 41 LE 73

\begin{tabular}{lcc} 
& Erequency & Average weight $(g)$ \\
\cline { 2 - 3 } & & \\
primary flakes & 0 & 17.55 \\
secondary flakes & 4 & 4.35 \\
interior flakes & 13 & 1.50 \\
fragments & 8 & $(8.30)$ \\
chunk & 1 & \\
& - &
\end{tabular}


Other artifacts: Several fire-cracked chert and quartzite fragments and an unmodified quartz cobble were also collected.

\section{Historic Component (Mills Homestead)}

The historic component at 41 LE 73 consists of a 1 ight scatter of debris, mostly ceramic tableware and glass and ceramic container remains, on the surface immediately south of the stock tank (Fig. 8, area A), plus a few scattered artifacts recovered from the nearby dirt road (area B). The main concentration is very sma 11, estimated at no more than about $5 \times 7 \mathrm{~m}$ in size and is located at the foot of the hil1 (at about 490 feet elevation) just above the floodplain of the intermittent creek to the north and west. No structural remains (foundation rocks, nails, or window glass) were found, raising the possibility that the historic component is a dump rather than an occupation site. No artifact concentrations of comparable age were found elsewhere in tract 8 . The only construction feature present at the site (aside from more recent terraces and a stack tank) is a north-south running ridge (an old road shoulder, turn row, or perhaps fill deposited during construction of the stock pond dam?) south of the debris scatter; it borders the floodplain meadow to the southwest.

Most of the artifact assemb 1 age appears to date from the $1860 \mathrm{~s}$ to $1870 \mathrm{~s}$, although some later artifacts are also present (Anne Fox, personal communication). Unfortunately, no legible maker's marks are present on any of the ceramics or glass. In Table 4, subdivided by surface collection units, is a synopsis of the historic debris.

\section{Ceramics}

Except for one yellow ware sherd, all of the pottery is either white earthenware or stoneware.

\section{White Earthenware}

A11 except one of the earthenware sherds are plain, although some could be from undecorated parts of decorated vesse 1s. About 10 of the sherds have a slight to pronounced blueish tint, evidently from the addition of cobalt to the glaze; in a few cases, smal1 specks of concentrated blue are visible in the glaze. Most of the blue-tinted sherds are base sherds, since the tinting is accentuated where the glaze has thickened against the footring during firing. Archaeologists have often termed such blue-tinted whiteware "pearlware," but the distinction between pearlware and ironstone is hazy, and in fact was not recognized by 19th-century English manufacturers themse 7 ves; Miller (1980, see especial1y Appendix A) gives a clear and intel1igent discussion of the 1 imited usefulness of these glaze distinctions. The amount of blue tint general1y declined during the 19th-century, although in the $1840 \mathrm{~s}$ and $1850 \mathrm{~s}$ blue-tinted plain ironstone became available (Miller 1980:17). Since the blue tint seems to have some chronological significance, specimens in this report will be listed as "blue-tinted earthenware," while untinted specimens will simply be 1 isted as "ironstone." It is perhaps 
TABLE 4. SURFACE HISTORIC DEBRIS, 41 LE 73

A. Central gul1y system

1 stoneware sherd with Bristol glaze

B. In or near road

1 yellow ware sherd

2 salt-glazed stoneware sherds: 1 body sherd with hematite(?) nodules in paste, 1 rim sherd with poorly developed glaze

4 white earthenware sherds

1 badly deformed lead bullet (too deformed to discriminate whether smoothbore or rifled; if a round bal1, then probably about .36 caliber)

I pale aqua glass round-based bottle sherd

1 brown whiskey/beer bottle sherd

C. South of stock pond

26 white earthenware sherds ( 1 has green and magenta hand-painted floral design; 1 blue-tinted sherd has just the edge of an impressed, illegible maker's mark; 4 rim sherds, including 1 saucer rim; 6 footring sherds, including 2 teacup sherds)

8 stoneware sherds (including a 1 arge alkal ine glazed churn or crock base sherd and 1 sherd, probably salt glazed, with Albany slip on the interior; a 11 the rest are probably salt glazed; Georgeanna Greer, personal communication)

1 probable bitters bottle sherd

2 green wine bottle body sherds; surfaces matte textured

1 clear glass tumbler base sherd

2 clear fused glass blobs

1 clear glass bottle sherd

1 brown glass whiskey/beer bottle sherd

1 thin brown glass (medicine?) bottle sherd

1 purple glass bottle sherd

I pale aquamarine glass bottle sherd

2 small irregular cut iron scraps

1 short length of drawn iron wire

1 iron machine screw

3 cast iron fragments (stove parts?), one flanged, one angled

1.22 caliber rimfire cartridge casing with "F" (Federa1) headstamp 
significant that none of the white earthenware from 41 LE 75 , thought to be a somewhat later occupation, is blue tinted.

Blue-Tinted White Earthenware (9 specimens, Fig. 9,a-b,e-f): In the collection are two rim sherds either from a very thin plate or a 7 arge saucer, possibly from the same vessel ( $F i g .9, a, b)$. Both have narrow rims about 3/16 inches wide. Plate base sherds and one probable bow 1 base are represented by two specimens with footrings that are rather flattened in cross section, plus a small plate base sherd with part of an impressed maker's mark, too incomplete for identification. Three probable teacup base sherds are present; two have peculiar footrings, distinctively bulbous in cross section ( $F$ ig. 9,e,f), while the third is tapering in cross section, from a heavier vessel.

Ironstone (2I specimens, Fig. 9,c,d,g-i): Two plate rim sherds of plain molded ironstone are present, possibly from the same plate (Fig. 9,c,d). A third is too small to determine if it had a molded rim. One ironstone jar 1 id sherd is present (Fig. 9,h). Three base sherds are of ironstone, two with footrings (Fig. 9,g). Most of the remaining 14 body sherds are probably from plates, although four may be from bowls or pitchers, including one handpainted body sherd (Fig. 9,i) with a green and magenta floral design. At least one of the sherds is heat discolored.

Abrasion: One interesting aspect of the tableware is the amount of abrasion visible. Localized 1 ight to heavy abrasion is present on the bottoms of footrings (both plates and cups), probably from storage or movement during use. Another kind of abrasion is represented by parallel groups of etch marks on both exterior and interior glaze surfaces. These may represent scouring with sand (Anne Fox, personal communication), and perhaps the degree of scouring indicates the frequency or length of use. About half the sherds are abraded, some of them heavily; al1 except two are ironstone.

\section{Yellow Glazed Earthenware}

A single body sherd of yellow-glazed earthenware, from a bow 1 or pitcher, was collected. Yel low ware genera $17 y$ dates after about 1880.

\section{Stoneware}

Salt-Glazed Stoneware (9 specimens, Fig. 9,j-0): The collection includes a sma 11, poorly glazed rim sherd (Fig. 9,j) from a vessel of unidentified type. The rim is about 1/4-inch thick. Another sherd (Fig. 9,k) may be a rim sherd, but the orientation shown in the figure is uncertain. Six of the remaining sherds are all body sherds with greenish gray to beige glazes that range from well developed with orange peel texture to poorly developed with matte texture. Interiors vary from well glazed to "toasted" brown (Fig. 9,1o). Another smal1 sherd has an Albany sip on the interior and a greenish glaze on the exterior that resembles an alkaline glaze, but is probably a salt glaze (Georgeanna Greer, personal communication). 
Figure 9. Historic Ceramics from the Mil1s Homestead, 41 LE 73. $a-i$, white earthenware; $j-0$, sa $7 t-g l$ azed stoneware; all are from area $A$ south of the stock pond, except for $j$ and 1 , which are from area $B$, the dirt road. Lines indicating horizontal $\mathrm{plane}$ of vessels are on the interior side of the vessel.

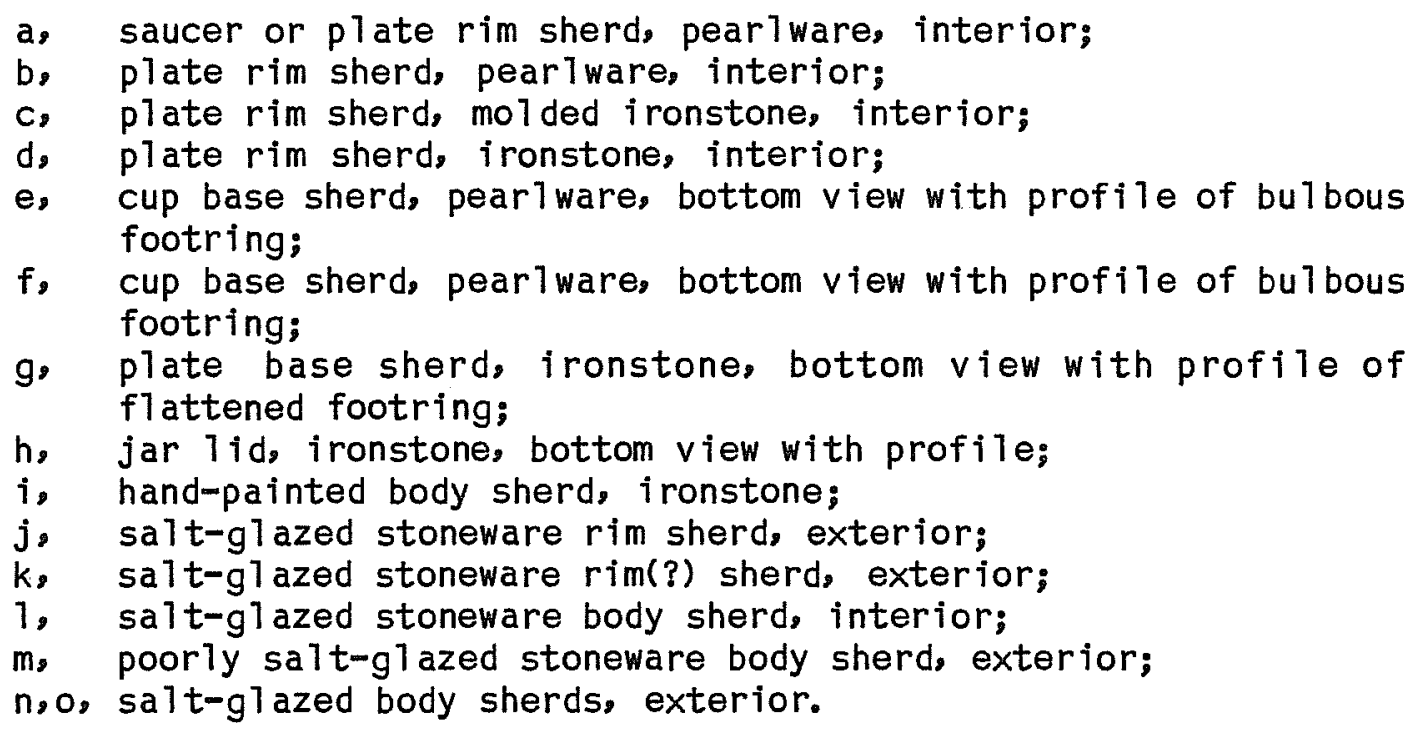



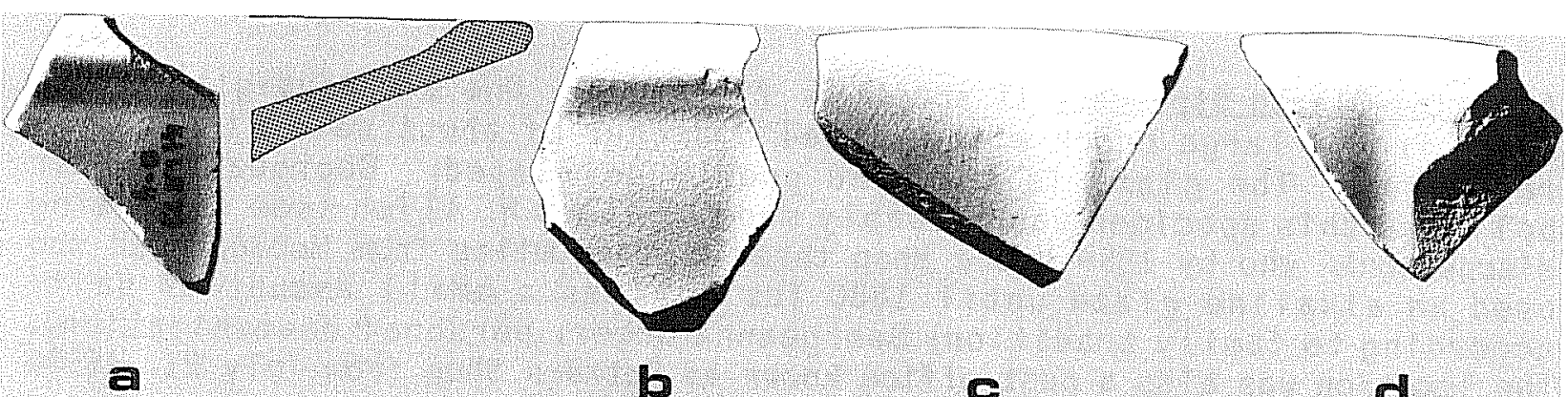

b

c

d
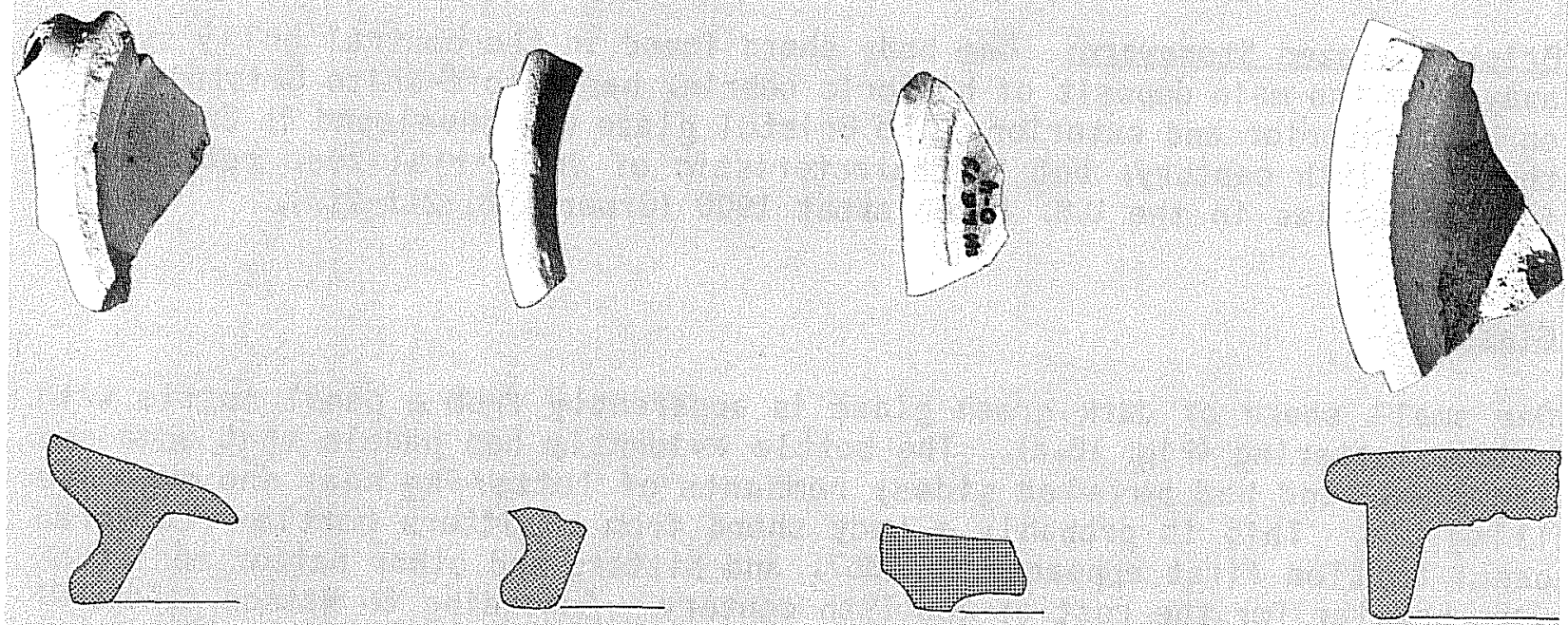

e

f

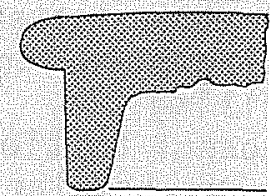

g

h
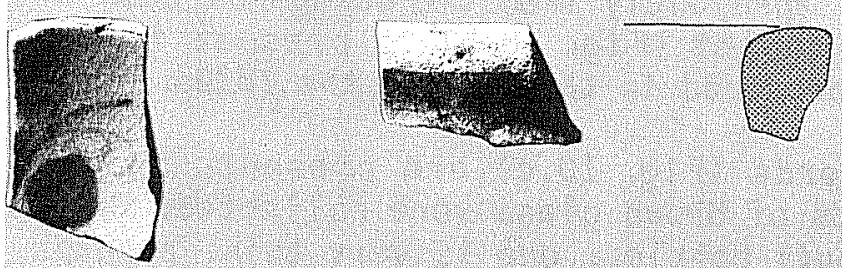

I

j
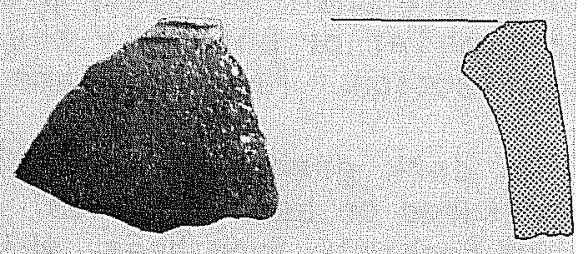

k
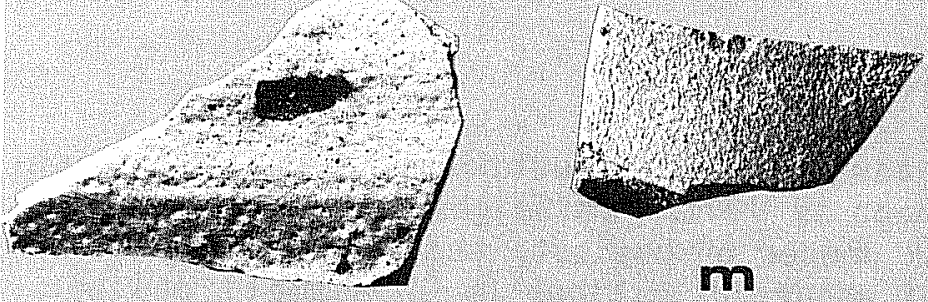

I

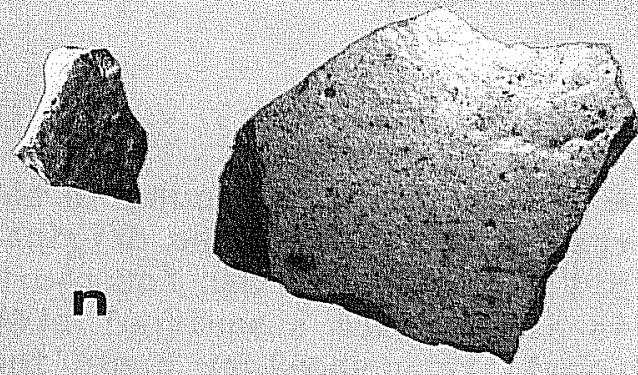

(다

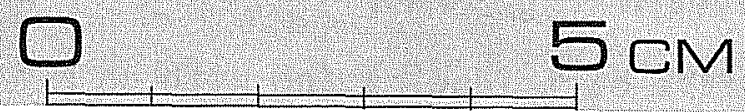


AlkalinemGlazed Stoneware (I specimen. Fig. 10, m): One alkaline-glazed base sherd from a 1 arge crock with a basal diameter of about seven inches was recovered. The glaze is thin and poorly developed. Georgeanna Greer bel ieves this specimen was probably made by James W. Alten (see foll lowing discussion), who by 1859 had a shop three or four miles from McDade, and who used an alkaline glaze until 1880 (as well as a sma11 amount of salt. according to family tradition: Georgeanna Greer, personal communication). The Tocation was also a post office known as Potters Shop from Ju7y 21, 1859, until October I, 1906 (Moore 1977:267).

Bristol-Glazed Stoneware: One body sherd found in the central gully system. away from the main deposit of historic debris, has an off-white Bristol glaze on both interior and exterior. The Bristol glaze was developed in England in the 1ate 19th century, but is characteristic of industrialized, rather than folk potteries in the U.S. after about 1900 (Greer 1981:211-212).

\section{Glass}

One smal1 sherd of dark green glass is apparently from a panel bottle with raised lettering ( $F$ ig. 10,a). The bottle evidently had panels that were not indented, and had beveled sides: remnants of lettering near one edge are illegible. This is probably a body sherd from a bitters bottle. Lettered panel bottles first appeared in 1867, and bitters and other patent medicines were popular for the rest of the 19th century. According to Watson (1965:39) early bitters bottles were aqua, with darker colors becoming more prevalent with time, and with amber the dominant color by 1870.

A single sherd of clear pressed glass, appa. ently from the octagonal base of a tumbler or possibly the body of a goblet (Fig. 10,b) is present in the collection. Pressed glass was being produced in the U.S. by the 1820s.

Two dark green wine bottle body sherds (Fig. 10,C) are present, matte textured on both surfaces. Three sherds of brown glass were collected: these are probably from beer, whiskey, or snuff bottles: one is very thin, perhaps from a medicine bottle or vial. Another bottle base sherd is of pale aquamarine glass. Miscellaneous glass consists of one clears one pale aqua. and one very pale purple glass sherd, all from bottles, plus two clear fused glass blobs.

\section{Metal}

A lead projectile found in the roadway is badly mushroomed from impacts so that no vestige of the original shape is left. It weighs $4.80 \mathrm{~g}$ (74 grains). Bill Woodward, a San Antonio black powder enthusiast, suggests this specimen is a ball from a squirrel rifle of about .36 caliber (e.g.s a small caliber. nonmilitary shoulder arm); the severe mushrooming indicates a powder charge too large for a sidearm ( $F$ ig. $10, f$ ).

A.22 caliber rimfire cartridge casing with an "F" (Federal) headstamp is presumably recent. 
Three badly rusted cast iron fragments found south of the stock pond ( $F$ ig. $10, g, h, n$ ) may be stove parts; one is flanged, another angled, the third flat. Other metal items are an iron or steel machine screw (Fig. 10,i), two smal1. irregular cut iron scraps (Fig. $10, j, k$ ), and a short length of drawn steel or iron wire (Fig. 10,1).

\section{Comments on the Collection}

A few observations of interest can be made about this smal1 collection. The relatively large proportion of stoneware sherds (a fourth of the ceramics) raises the possibility that some might have been made locally. In the 1 ate 19th century, stoneware was used primarily for food storage and processing (crocks, butter churns, and the 1ike). Stoneware production in Bastrop County was begun in 1856 or 1857 by Matthew and George Dunkin at a site just north of the present Bastrop State Park. An alkaline glaze was used chiefly from about the beginning of production to around 1870. By 1859, James W. A 11 en, a son-in-1aw, had a shop on Marsh Branch near McDade, just a few kilometers southeast of tract 8 , and owned some other property in present Lee County, where he might conceivably have operated another pottery. Another potter named Beatty is also 7 isted in the 1850 census of Burleson County, at B1ue Branch, but we do not know what, if anything, he produced. He is 1 isted 10 years 1 ater in the 1860 agricultural census as an active farmer. By 1870 another potter, Jacob Lewis, was also in operation at Oak $\mathrm{H}_{11} 1$ in the present Camp Swift area (Georgeanna Greer, personal communication). Dan M. Louis (1857-1895), another potter originally from Alabama, also had a pottery at Wayside Community, about three miles north of Oak Hill (Smith and Pannell 1984:10-11). History does not record what was mined on Mine Creek, but it seems possible it might have been potter's clay, perhaps mined by one of these early $10 \mathrm{ca} 1$ potters. In any case, $10 \mathrm{ca} 11 \mathrm{y}$ produced stoneware was certainly available during the early settlement of the area.

Two pieces of molten glass and a heat-discolored ironstone sherd may indicate burning of trash deposits.

Some items (such as the Bristol-glazed stoneware sherd, the drawn wire, the .22 cartridge casing, the machine screw, and perhaps the stove parts) seem to date later than the initial occupation.

\section{History of Land Ownership}

Tract 8 was first a part of Milam County under the original Repub 1 ic of Texas system of counties, then in 1846 became a part of Burleson County when it was organized, and remained a part of Burleson County unti 11874 when Lee County was created. The southwestern boundary of tract 8 is the present Lee County 1 ine (Fig. 6). The site now designated 41 LE 73 1ies in a 160-acre tract of 1 and patented to William B. Mauldin (variously spel1ed Mouldin, Ma1den, etc., in the records) ". . . in Burleson County on the waters of Mine Creek about 34 miles S. 72 [degrees] W. from Caldwe 17 issued in accordance with an act for the relief of Wm. B. Mouldin passed February 10th, 1858." The letter patent is dated March 13, 1860, but was not filed until 1925 (tract 8 , Abstract of Title, page 165). As shown on recent USGS maps of the area, 
Figure 10. Prehistoric and Historic Artifacts, 41 LE 73. A11 are from area $A$ south of the stock pond, except for $d$ and $f$, which are from area $B$, the dirt road; and $e$, which is from area $C$, the central gul1y system.

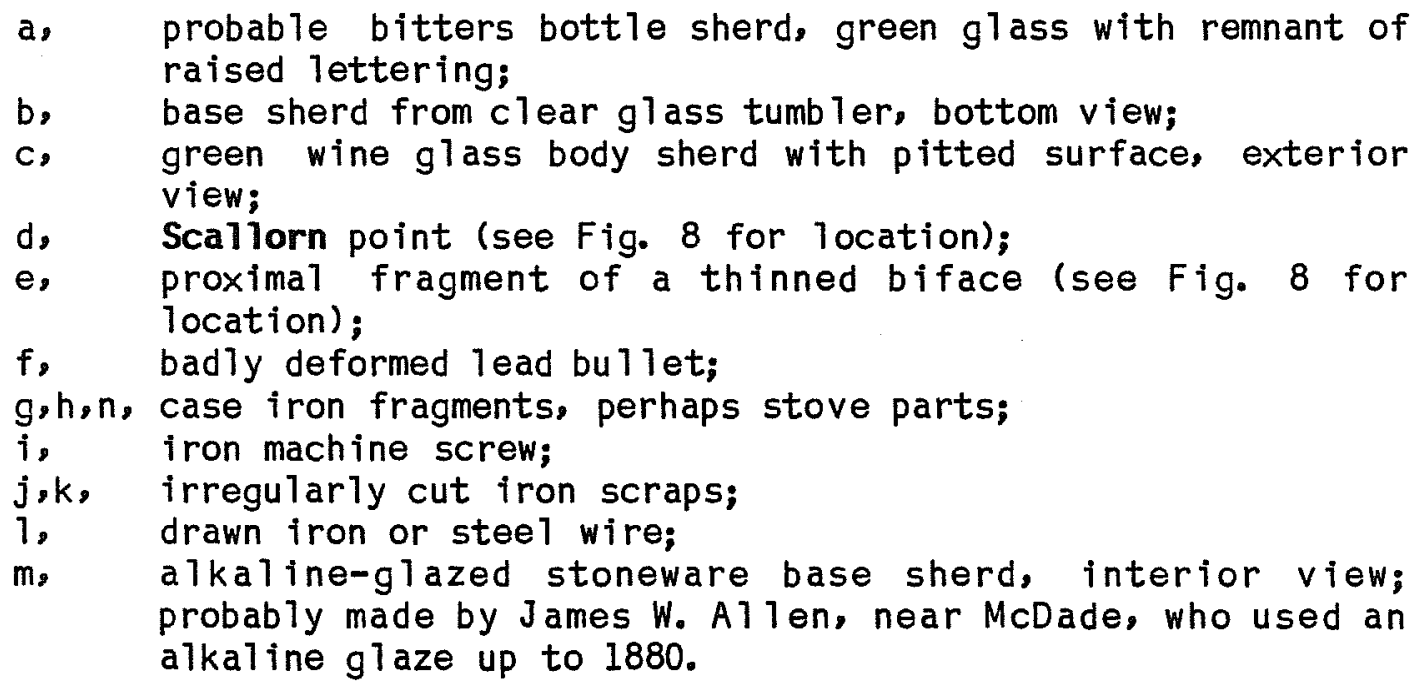
probably made by James W. Al 1 en, near MCDade, who used an alkaline glaze up to 1880 .

Note: Items a-f are shown at twice the scale of items $g-n$; items $d$ and e have been opaqued for photography. 


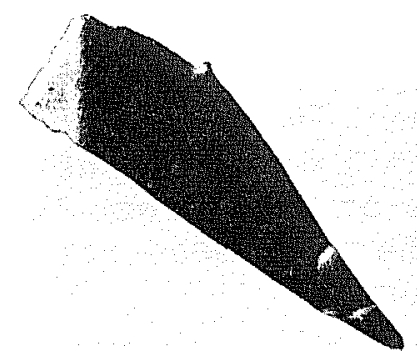

a

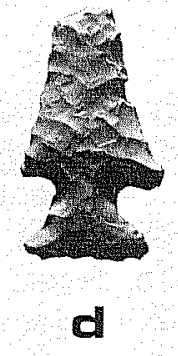

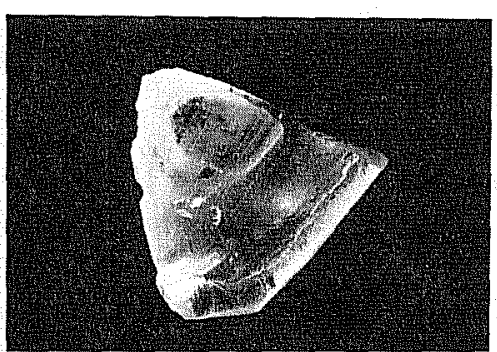

$b$

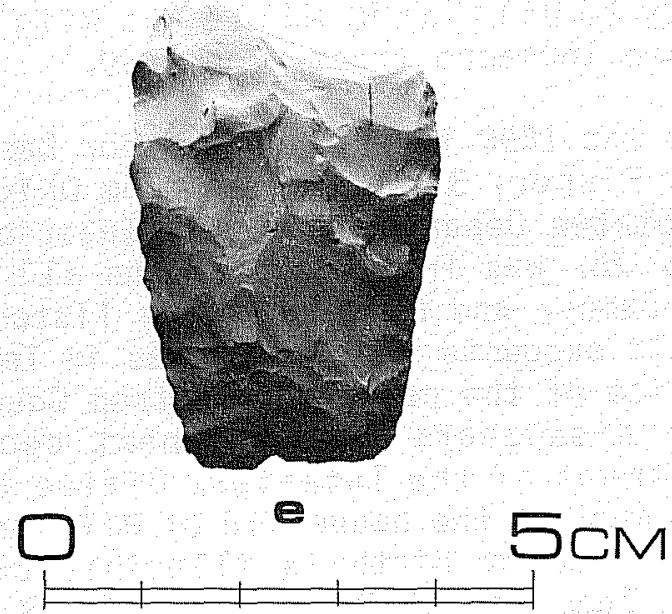

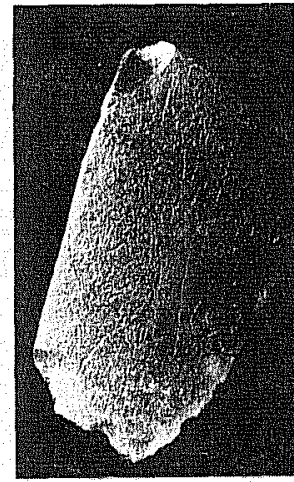

c

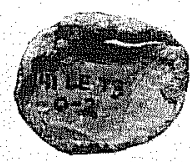

$f$
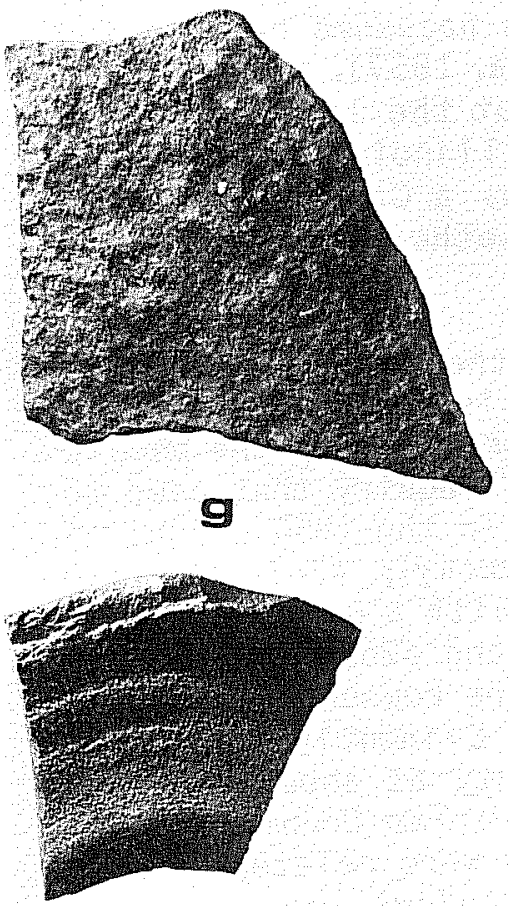

กา
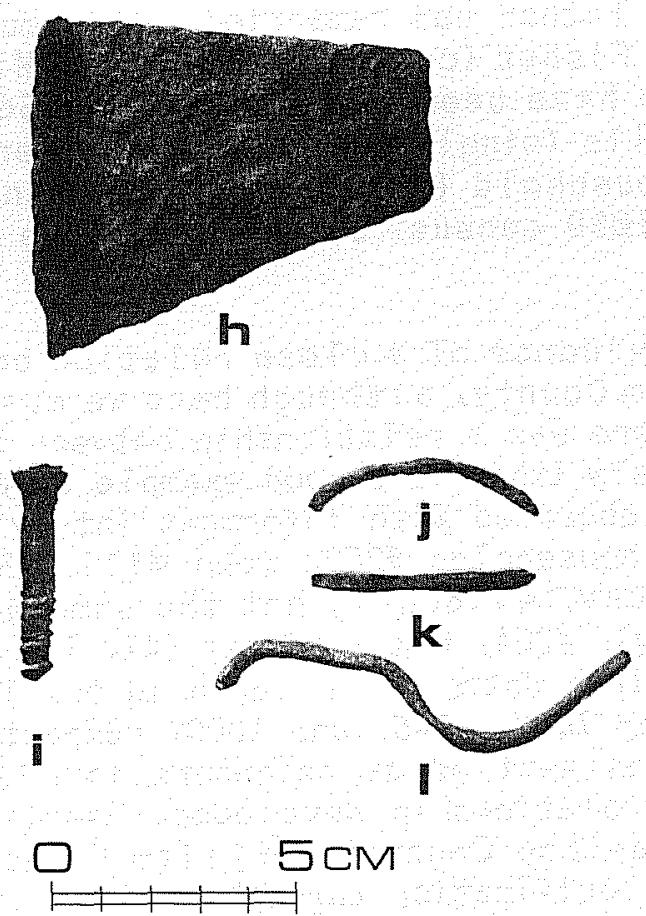

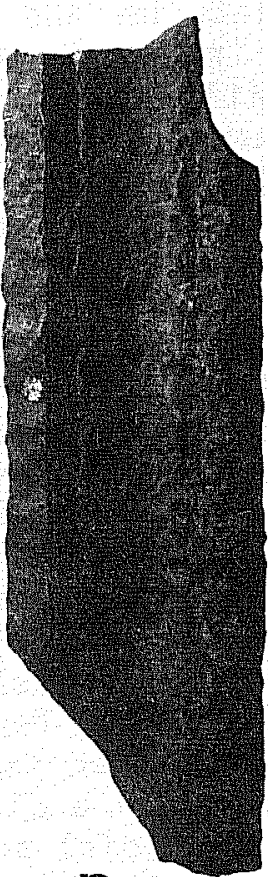

n 
Willow Creek is a tributary of Mine Creek, entering it about $4 \mathrm{~km}$ northeast of tract 8. Earlier maps (Bastrop quad, 1904) are unlabeled. The metes and bounds for several of the tracts of 1 and comprising tract 8 mention Mine Creek, several referring specifically to the "south side of Mine Creek," implying that what is now marked as Willow Creek on the USGS maps was considered to be a part of Mine Creek in the 1ate 19th century.

It seems 1 ikely that Mauldin was an absentee owner, never 1 iving on the 1 and, for in a deed dated just two weeks 1 ater, on March 27, 1860, notarized the following day at Hallettsville and filed January 22, 1863, in Burleson County, ". . Wil1iam B. Mauldin and wife Elizabeth Mauldin of Lavaca County, Texas, convey to Wi11 iam R. Mi11s and wife L. J. Mil1s of Burleson County, Texas" the same 160-acre tract, for $\$ 300$.

Ten years earlier, in the 1850 federal census for Bastrop County (Tab1e 5), a man named Wil1 iam H. Fisher, 35, a farmer from Ohio, was 1 isted as householder \#186 United States Department of the Interior, Office of the Census 1850). His wife Jane, 26, was from Alabama, and al1 five children (William, David, Elizabeth A., James, and Eliza J.) were listed as born in Texas. The age of the oldest child suggests the family was in Texas by 1842. Fisher had been appointed a justice of the peace for Bastrop County on February 27, 1845 (Moore 1977:58). He disappears from the next decennial census in 1860 (United States Department of the Interior, Office of the Census 1860), but his family appears as part of the household of Wil1iam Mi11s, 35, a farmer in Burleson County (his state of birth is illegible but might read Missouri). His wife is 1 isted as Jane Mil1s, 36, born in Texas. Presumably the birthoo place is an error, and she was the same as the Jane Fisher 1 isted in the 1850 Bastrop County census (certainly the ages agree), as well as the L. J. Mills listed in the deed. Evidently William Fisher had died (or divorced) in the interim, and Jane Fisher had remarried. This must have happened between the birth of Jemmima Fisher (ca. 1853) and Lydia Mi11s (ca. 1857). At any rate Mi11s appears to have been in the area by 1856-1857 at the 1 atest. A man named William Mills (single, 24-year-old farmer from Illinois) is 1 isted as living in the household (\#79) of Wil1 iam Kingsberry, a Caldwel1 County dentist, in the 1850 census, but we cannot be sure whether he is the same man.

There is other evidence of a close relation between the Mills and Fisher families in Milam County, although here we must exercise caution since we cannot be sure there was a relationship between these families and the people mentioned previously (this is a good example of areas of inquiry that need to be verified or elaborated with informant interviews). In the 1850 census of Milam County are households \#262, John Mi11s (38, Kentucky); \#263, William Milis (34, Kentucky, evidently not the same man but with a wife Jane, 30 , a 1 so from Kentucky); \#264, Moses Fisher (42, I11 inois); and \#265, King Fisher (45, I11inois). Birth dates of children in the last three households suggest entry into Texas by 1847,1845 , and 1850, respective1y. Evidently the Mi11s and Fisher families settled as neighbors in Milam County at about the same time and a close relationship developed, assuming the Milam County Fishers (I 11 inois) and Bastrop County's William Fisher (Ohio) were related in some way. This needs clarification through oral history interviews. 
The 1860 Burleson County census does not, of course, pinpoint the location of dwe 11 ing \#595, but the adjacent households (\#596, J. G. Willett; \#597, David Scott; \#598, Joseph Ferguson; \#599, James F loyd) a 11 correspond to 1 andowners on the north side of Mine (Willow) Creek detailed in the Abstract of Title (n.d.). Mills valued his real estate at $\$ 350$, although he had paid Mauldin $\$ 300$ for $i t$, and valued his personal estate at $\$ 242$. Mil 1s is not 1 isted in the 1860 census as a slaveholder (the on $1 \mathrm{y}$ slaveholder 1 isted in the area was James Floyd). The 1860 agricultural census (Table 6) shows that, as of the month of June in that year, Mills had not produced much, even by comparison with his neighbors. With 15 acres under cultivation, he had produced just 25 bushels of corn, considerably less than the average contemporary yield for Bur leson County (Texas A1manac 1867:84). Whi 1e Mi1 is had on $1 \mathrm{y}$ five milch cows and 16 hogs or pigs, he had slaughtered $\$ 400$ worth of animals earlier in the year. The low level of production might indicate that Mills had not been estab 1 ished on the 1 and 1 ong enough to achieve 7 arge yields.

William R. Mil1s has not yet been located in the 1870 census of Burleson County and is apparently absent from the Blue Branch and Lexington precincts. In the 1870 census of Bastrop County, a W. R. Mi11s, 46, farmer from Kentucky, is 1isted (dwe11ing \#598, family \#650) as 1 iving alone, but with a Martha Mi11s, 18, a 1 so born in Kentucky, 1isted as keeping house for 11 other unrelated members of an adjacent household (United States Department of the Interior. Office of the Census 1870). While this man's age agrees closely with that of William R. Mi11s (born ca. 1825), his daughter Martha should have been 11, not 18, in 1870 and was born in Texas.

The 1 and remained in the family until 1919, when the Fisher and Milis families sold 100 acres of the tract to T. W. Owen of Bastrop County; evident 1 y Owen 1 ived on the 1 and for a time (tract 8 , Abstract of Titie n.d.: 167-170).

To recapitulate, Mills and his family clearly settled on the Mauldin survey by at least 1860. It is possible they may have settled here a few years earlier, since the birth date of Lydia Mills implies Mills had married Jane Fisher of Bastrop County by 1856 or 1857. In the early settlement of Texas it was not uncommon to find settlers $1 \mathrm{iving}$ on the 1 and before they had acquired legal title to it. Mills' neighbor David Scott acquired title to his 1 and in 1859, but from the birth dates of his children we know he was in Texas by 1849 (he appears in Bastrop County in the 1850 census). James Floyd also acquired title to his 7 and in 1859, but again there is evidence he was in Texas by 1856. It seems possible that at least some of these families might have moved onto tract 8 before buying the 1 and.

\section{Recommendations for 41 LE 73}

The historic component at this site appears to be essentially a surface deposit, possibly a dump area if the 1 ack of structural debris is significant. We probably have not yet located the actual dwelling site. The prehistoric component has been badly disturbed both by cultivation, terrace building, and topsoil erosion. Unless a part of the historic component with better preservation (such as the location of the Mills dwel1ing) can be located, no testing or excavation is recommended. 
TABLE 5. EXCERPTED FEDERAL CENSUS RECORDS FOR 1850 AND 1860

Dwelling Family Name Age Sex Birthplace

\section{Census, Bastrop County}

\begin{tabular}{|c|c|c|c|c|c|}
\hline$\# 186$ & 199 & $\begin{array}{l}\text { William H. Fisher } \\
\text { Jane } \\
\text { William } \\
\text { David } \\
\text { Elizabeth A. } \\
\text { James } \\
\text { Eliza J.* }\end{array}$ & $\begin{array}{r}35 \\
26 \\
8 \\
6 \\
4 \\
3 \\
1\end{array}$ & $\begin{array}{l}M \\
F \\
M \\
M \\
F \\
M\end{array}$ & $\begin{array}{l}\text { Ohio } \\
\text { Alabama } \\
\text { Texas } \\
\text { Texas } \\
\text { Texas } \\
\text { Texas } \\
\text { Texas }\end{array}$ \\
\hline$\$ 167$ & 179 & $\begin{array}{l}\text { David Scott } \\
\text { Elizabeth } \\
\text { Martha } \\
\text { Sarah A. }\end{array}$ & $\begin{array}{c}34 \\
20 \\
1 \\
3 \text { months }\end{array}$ & $\begin{array}{l}M \\
F \\
F \\
F\end{array}$ & $\begin{array}{l}\text { Georgia } \\
\text { Texas } \\
\text { Texas } \\
\text { Texas }\end{array}$ \\
\hline
\end{tabular}

1860 Census, Burleson County

\#595

587

William Mills
Jane Mills
Wm Fisher
David Fisher
Elizabeth Fisher
James Fisher
Jane Fisher*
Jemmima(?) Fisher
Lydia Mills
Margaret Mills
Martha Mills

$\begin{array}{rll}35 & \text { M } & \text { illegible } \\ 36 & \mathrm{~F} & \text { Texas** } \\ 19 & \mathrm{M} & \text { Texas } \\ 17 & \mathrm{M} & \text { Texas } \\ 15 & \mathrm{~F} & \text { Texas } \\ 12 & \mathrm{M} & \text { Texas } \\ 9 & \mathrm{~F} & \text { Texas } \\ 7 & \mathrm{~F} & \text { Texas } \\ 3 & \mathrm{~F} & \text { Texas } \\ 2 & \mathrm{~F} & \text { Texas } \\ 1 & \mathrm{~F} & \text { Texas }\end{array}$

\#596

588

J. G. Willett

42

(dependants omitted here)

\#597

589

David Scott

45

E. Scott

Sarah A.

Mary

James

William H.

Jonathan

David

\#598

590

Joseph Ferguson

(dependants omitted here)

$\begin{array}{rll}45 & M & \text { Georgia } \\ 28 & F & \text { Texas } \\ 10 & F & \text { Texas } \\ 9 & F & \text { Texas } \\ 7 & M & \text { Texas } \\ 6 & M & \text { Texas } \\ 2 & M & \text { Texas } \\ 1 & M & \text { Texas }\end{array}$

27

M

Tennessee 
TABLE 5. (continued)

\begin{tabular}{|c|c|c|c|c|c|}
\hline Dwelling & Family & Name & Age & Sex & Birthplace \\
\hline$\$ 599$ & 591 & $\begin{array}{l}\text { James Floyd } \\
\text { Mary } \\
\text { James*** } \\
\text { William } \\
\text { Young*** } \\
\text { slave } \\
\text { slave } \\
\text { slave }\end{array}$ & $\begin{array}{r}57 \\
41 \\
16 \\
7 \\
4 \\
80 \\
45 \\
50\end{array}$ & $\begin{array}{l}M \\
F \\
M \\
M \\
M \\
F \\
M \\
M\end{array}$ & $\begin{array}{l}\text { Georgia } \\
\text { South Carolina } \\
\text { South Carolina } \\
\text { South Carolina } \\
\text { Texas } \\
\text { unknown } \\
\text { unknown } \\
\text { unknown }\end{array}$ \\
\hline
\end{tabular}

\#602 594 W. H. Hobbs

\#604 596 Joseph B. Scott

1870 Census, Burleson County

\#315 335

James Floyd
Mary K.
William B.
Young D.
Peter Floyd****

$\begin{array}{ll}68 & M \\ 50 & F \\ 16 & M \\ 14 & M \\ 20 & M\end{array}$

Georgia

South Carolina

Texas

Texas

Louisiana

\section{Census, Bastrop County}

\#690

766

David Scott*****
Elisab.
Sarah
Maria
James
Henry(?)
Oscar
Mandy
A1ice
Frank
infant

$\begin{array}{lll}49 & M & \text { Alabama } \\ 39 & F & \text { Texas } \\ 17 & F & \text { Texas } \\ 16 & F & \text { Texas } \\ 13 & M & \text { Texas } \\ 10(?) & M & \text { Texas } \\ 12 & M & \text { Texas } \\ 8 & F & \text { Texas } \\ 6 & F & \text { Texas } \\ 3 & M & \text { Texas } \\ 6 / 12 & \text { (?) } & \text { Texas }\end{array}$

* Eliza J. probably is "Eliza Jane" or simply "Jane."

* Presumabiy an error(?).

** See discussion of 1 and ownership for 41 LE 75 for roles of these members in the Notchcutter wars.

**** A black farm hand.

***** Scott sold his 1 and in 1862 and moved to Bastrop County, where he is 1 isted in the muster roll of Co. D, 3rd Battalion of Mounted Reserves, CSA, in 1865 (Moore 1977:85) at Camp Scott. He is a 1 so 1 isted in the 1867 pol1 of registered voters in Bastrop County (White 1983:219).

NOTE: Some census data omitted for brevity. 
TABLE 6. AGRICULTURAL PRODUCTION IN 1860 BY LANDOWNERS IN THE PREWITT, MAULDIN, BANKSTON, AND ADJACENT SURVEYS

\begin{tabular}{|c|c|c|c|c|c|c|c|c|c|c|c|c|c|c|c|c|c|c|c|c|c|}
\hline & 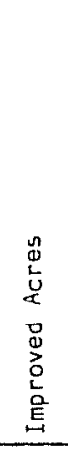 & 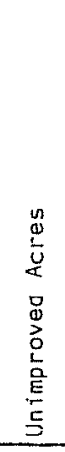 & 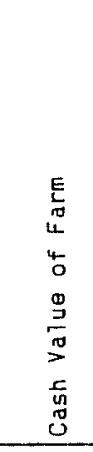 & 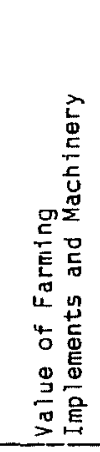 & $\begin{array}{l}\text { 年 } \\
\text { 心 } \\
\vdots \\
0 \\
\end{array}$ & 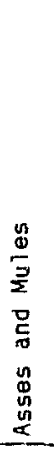 & 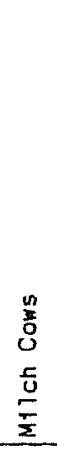 & 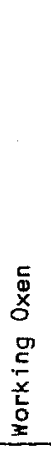 & 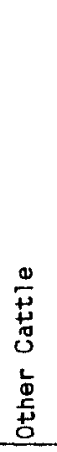 & 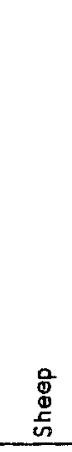 & $\stackrel{\substack{n \\
n}}{n}$ & 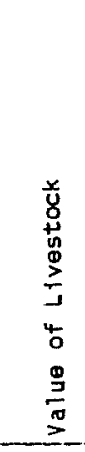 & 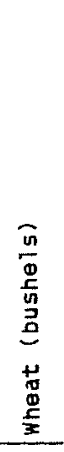 & 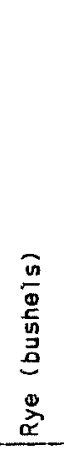 & 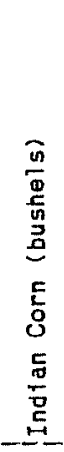 & 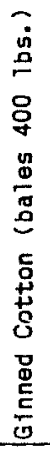 & 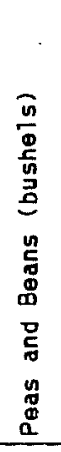 & 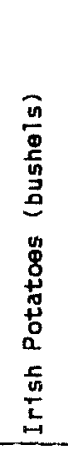 & 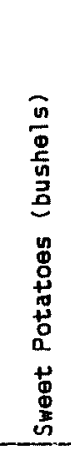 & 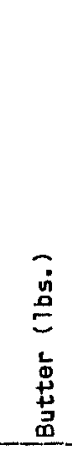 & 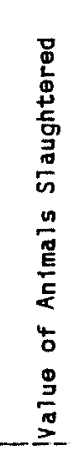 \\
\hline Wm. Mills & 15 & 145 & $\$ 350$ & $\$ 20$ & 0 & 0 & 5 & 2 & 0 & 0 & 16 & $\$ 142$ & 0 & 0 & 25 & 0 & 0 & 0 & 0 & 0 & $\$ 400$ \\
\hline J. G. Willett & 30 & 170 & $\$ 1000$ & $\$ 100$ & 1 & 0 & 5 & 4 & 10 & 0 & 80 & $\$ 475$ & 0 & 0 & 50 & 4 & 0 & 10 & 0 & 40 & 0 \\
\hline David Scott & 35 & 117 & $\$ 800$ & $\$ 10$ & 1 & 0 & 5 & 2 & 25 & 0 & 30 & $\$ 310$ & 0 & 0 & 50 & 1 & 20 & 0 & 0 & 100 & $\$ 84$ \\
\hline Jas. Floyd & 100 & 800 & $\$ 3600$ & $\$ 1000$ & 9 & 2 & 10 & 14 & 75 & 150 & 60 & $\$ 2665$ & 0 & 0 & 200 & 1 & 0 & 5 & 5 & 100 & $\$ 800$ \\
\hline Wm. R. Hobbs & 45 & 395 & $\$ 1200$ & $\$ 100$ & 4 & 1 & 4 & 2 & 20 & 57 & 190 & $\$ 1344$ & 63 & 16 & 15 & 1 & 0 & 0 & 100 & 200 & $\$ 225$ \\
\hline Joseph Scott & 15 & 145 & $\$ 400$ & $\$ 100$ & 2 & 0 & 3 & 4 & 0 & 0 & 40 & $\$ 316$ & 0 & 0 & 120 & 2 & 0 & 0 & 0 & 0 & 0 \\
\hline
\end{tabular}
Source: United States Department of the Interior, Office of the Census, Returns of Schedule Four, Agriculture, Burleson
County, August 20, 1860 . 
In November 1984, the eight-acre area north of Highway 696 and south of Will low Creek was reexamined in hopes of locating further debris from the Mil1s occupation. Some large stoneware crock sherds were found, but nothing that appeared contemporaneous with the Mi11s occupation was seen.

\section{LE 74}

A prehistoric site, 41 LE 74, is simply a very smal1 scatter of chipping debris exposed in a shal1 ow gul1y on the north side of Wil1 ow Creek, just below 480 feet in elevation (Fig. 1). The southward-draining gully is at the southwest corner of an abandoned field, near the creek cutbank, on 1 y $50 \mathrm{~m}$ or so from the present channel and about $3 \mathrm{~m}$ above it. This site 1 ies about $475 \mathrm{~m}$ west-southwest of the recorded location of another site (4l LE 63) reported by Kel1y and Roemer (1981:6), although we were unable to relocate the site in the field, possibly because no additional artifacts had been exposed by erosion since the phase I survey. Both sites are similar in situation and content, and at 41 LE 74, the gul $7 y$ has cut through about 40$45 \mathrm{~cm}$ of sandy loam (evidently an in situ soil, not al 1uvium) and into the underlying mottled orange clay. To the west, a narrow but deep bifurcate drainage traverses a remnant wooded area and enters Wi11 ow Creek $450 \mathrm{~m}$ southwest of the site.

The area covered by the chipping debris is on $1 \mathrm{y}$ about $2 \times 5 \mathrm{~m}$ across and is confined to the gul1y, 1ittle more than a shallow swale. Despite a careful search, only nine smal1 pieces of chipping debris and a possible biface 1 ateral fragment could be found. No fire-cracked rock was seen. The collection represents mostly biface thinning debris and includes two smal1 but wel 1 formed, 1 ipped thinning flakes. The uniform 1 y smal1 size of the flakes and similarity of most of the raw material is notable. Debris classes and average weights are given in Table 7.

Field work at this site consisted of a brief examination and careful surface collection, a sketch map, photography, and two shovel tests. One shovel test was placed immediately west of the gully edge, but inside the fence, while another was located about 50-60 m east-southeast of the site, near the creek. Nothing was found in either shovel test.

TABLE 7. SURFACE CHIPPING DEBRIS, 41 LE 74

Erequency

primary flakes secondary flakes interior flakes flake fragments
0

2

3

4
Average Weight (g)
2.70
0.17
0.45 


\section{Recommendations for 41 LE 74}

Site 41 LE 74 is presumably a very small work station of some kind, with very few artifacts present, judging by the exposure in the gul1y. Erosion and cultivation have probably disrupted the site; no cultural material was seen in the field around the gully. No further field work is recommended.

\section{LE 75}

Site 41 LE 75 is a smal1 scatter of 1 ate 19th-century historic debris exposed in a gul1ied area at the west corner of tract 8. The site, at about 490-500 feet elevation, is about $40 \mathrm{~m}$ southwest of Willow Creek, here a rather smal1 narrow stream in comparison to its nature a short distance downstream at 41 LE 74. At the time of our visit it held water near the site only in smal1 discontinuous pools. The site is enclosed by a fence $5 \mathrm{~m}$ to the northwest and another fence forming the Lee/Bastrop County 1 ine $7 \mathrm{~m}$ to the southwest (Fig. 7). Here there is a large, deeply gul1ied area that has been stripped of vegetation, topsoil, and much of the underlying clay substrate to a depth of a meter or so. Most of the debris was found in the gul1y, especial1y at the foot of the eastern gu $11 \mathrm{y}$ wa11, a though a few items were found on the undisturbed surface above and to the east. The area across the fence to the northwest and across the fence to the southwest in Bastrop County has not been examined yet, so we are not certain that the site does not extend into these areas.

Field work consisted of a brief inspection and surface collection, and photography; no shovel tests were dug.

The debris scatter is estimated at about $7 \times 10 \mathrm{~m}$ in size, and 1 ike the scatter at 41 LE 73, contains no structural debris. The collection consists entirely of ceramic and glass containers and ceramic tableware and may represent a trash dump associated with a nearby residence. The collection as a whole appears to date around 1880 (Anne Fox, personal communication). Also col 1 ected were two chert $f 1$ ake fragments and three pieces of fire-cracked rock (see Table 8 for a complete synopsis of the collection).

\section{Ceramics}

\section{White Earthenware}

Eight plain ironstone sherds were collected. One plate base sherd (Fig. 1I,a) has a printed maker's mark:

\section{IMPERIAL}

IRONSTONE CHINA

HOPE \& CARTER

Immediately below is a circular impressed maker's mark. Partially legible, it appears to read "HOPE \& CARTER" above, with "IRONSTONE" below. According to Godden (1964:334), this firm operated from 1862 to 1880. The other ironstone sherds consist of two (bowl?) rim sherds, a large tureen rim sherd, and 


\section{TABLE 8. SURFACE HISTORIC AND PREHISTORIC DEBRIS, 41 LE 75}

A. Historic debris

8 ironstone sherds; one has "Imperial Ironstone China Hope \& Carter" maker's mark; three are rim sherds (Fig. 1l,b)

3 slip-glazed stoneware sherds (Albany slip on both surfaces, including two 1 arge milk bow 1 sherds)

1 alkaline-glazed stoneware body sherd

4 pale aquamarine glass sherds, including the neck of a probable ink bottle, with hand-finished 1 ip, and two panel bottle sherds (Fig. $11, h, i$ )

1 pale olive wine bottle sherd

1 clear glass bottle sherd

2 brown glass snuff bottle rim sherds (Fig. $11, j$ )

3 brown glass whiskey/beer bottle sherds

2 pale aquamarine panel bottle sherds with raised letters, "PA" and "ON" or "NO" (?)

15 purple glass bottle sherds, probably representing at least 2 pane 1 bottles

B. Prehistoric debris*

2 chert flake fragments; one has a smal1 area of unifacial retouch at one corner, originating from the ventral surface

2 fire-cracked chert fragments

1 fire-cracked quartzite fragment

* Fire-cracked rock is assumed to be prehistoric rather than historic.

four sherds of unknown vessel type. One sherd has severe scouring, but as a group these sherds are not as heavily abraded as the whiteware from 41 LE 73.

\section{Stoneware}

\section{Alkal ine-Glazed Stoneware}

One small stoneware body sherd (Fig. $11, \mathrm{C}$ ) has a heavy alkaline glaze on both surfaces. Georgeanna Greer believes this specimen is probably from the Dunk in Pottery, operated from 1856 or 1857 to 1880 by Matthew Dunk in and the elder George Dunkin, north of the present Bastrop State Park. The principal use of alkaline glaze at this pottery was from 1856 to 1870 (Greer, personal communication).

\section{Slip-Glazed Stoneware}

Three stoneware sherds have dark brown Albany slip glazes on both surfaces. Two are heavy milk bow 1. rim sherds (Fig. 11,d), while the third, a body 
Figure 11. Historic Artifacts, 41 LE 75; Tract 8 Iso 1 ated Finds. $a-j$ are from the surface of 41 LE $75 ; k$ and 1 are isolated finds from el sewhere in tract 8.

a, ironstone base sherd with Hope \& Carter maker's mark;

b. ironstone bowl(?) rim sherd;

c, alkaline-glazed stoneware body sherd, probably from Dunk in Pottery, near present Bastrop State Park (principal use of alkaline glaze occurred 1856-1870), exterior view;

d, Albany slip milk bow 7 rim sherd, probably from McDade Pottery operated by Milton Stoker (late 1880s-1890s), interior view;

e, neck fragment of pale aquamarine glass bottle, cork-stoppered;

$f$, amethyst glass bottle base sherd, bottom view;

g. pale aquamarine panel bott le sherd, orientation uncertain; identical in color to e;

h,i, pale aquamarine panel bottle sherds with raised letters;

$j$, snuff bottle rim sherd;

$k$, tract 8 isolated find, blue edged ware rim sherd;

1. tract 8 isolated find, salt-glazed stoneware preserve jar(?) rim sherd. 


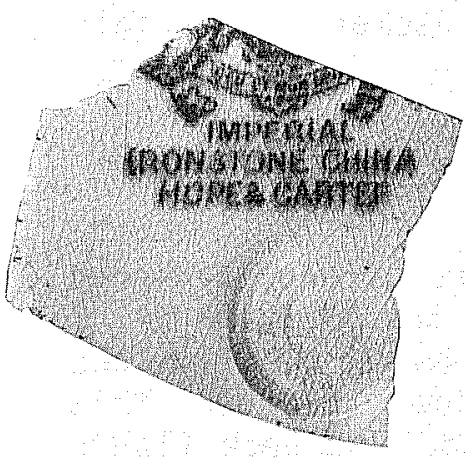

a
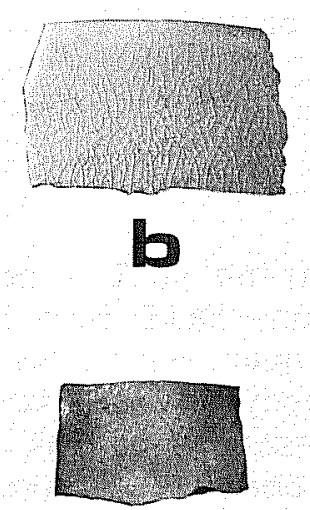

잠
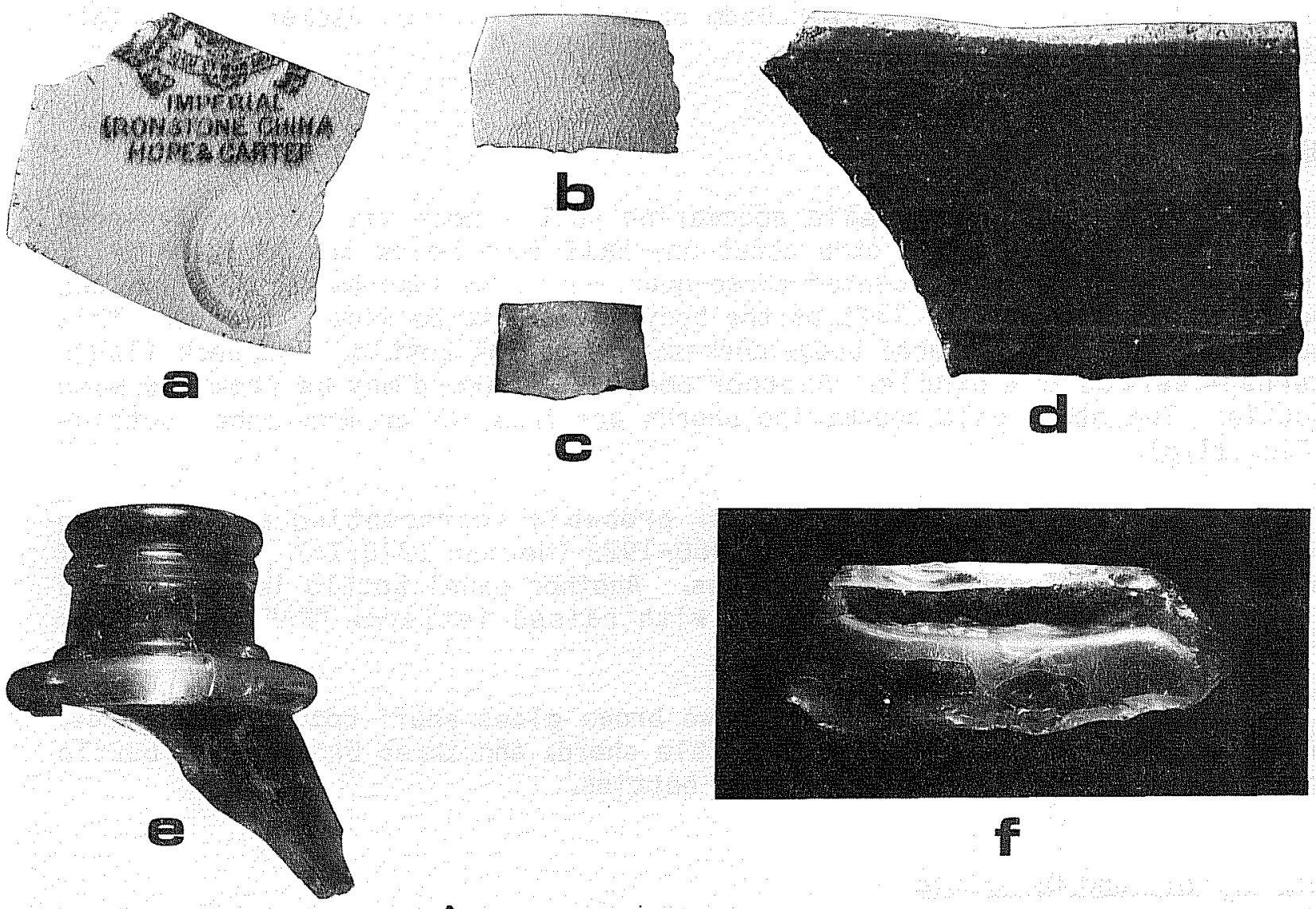

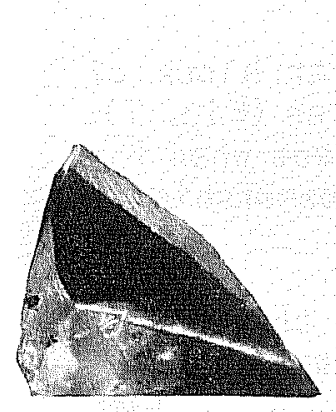

9
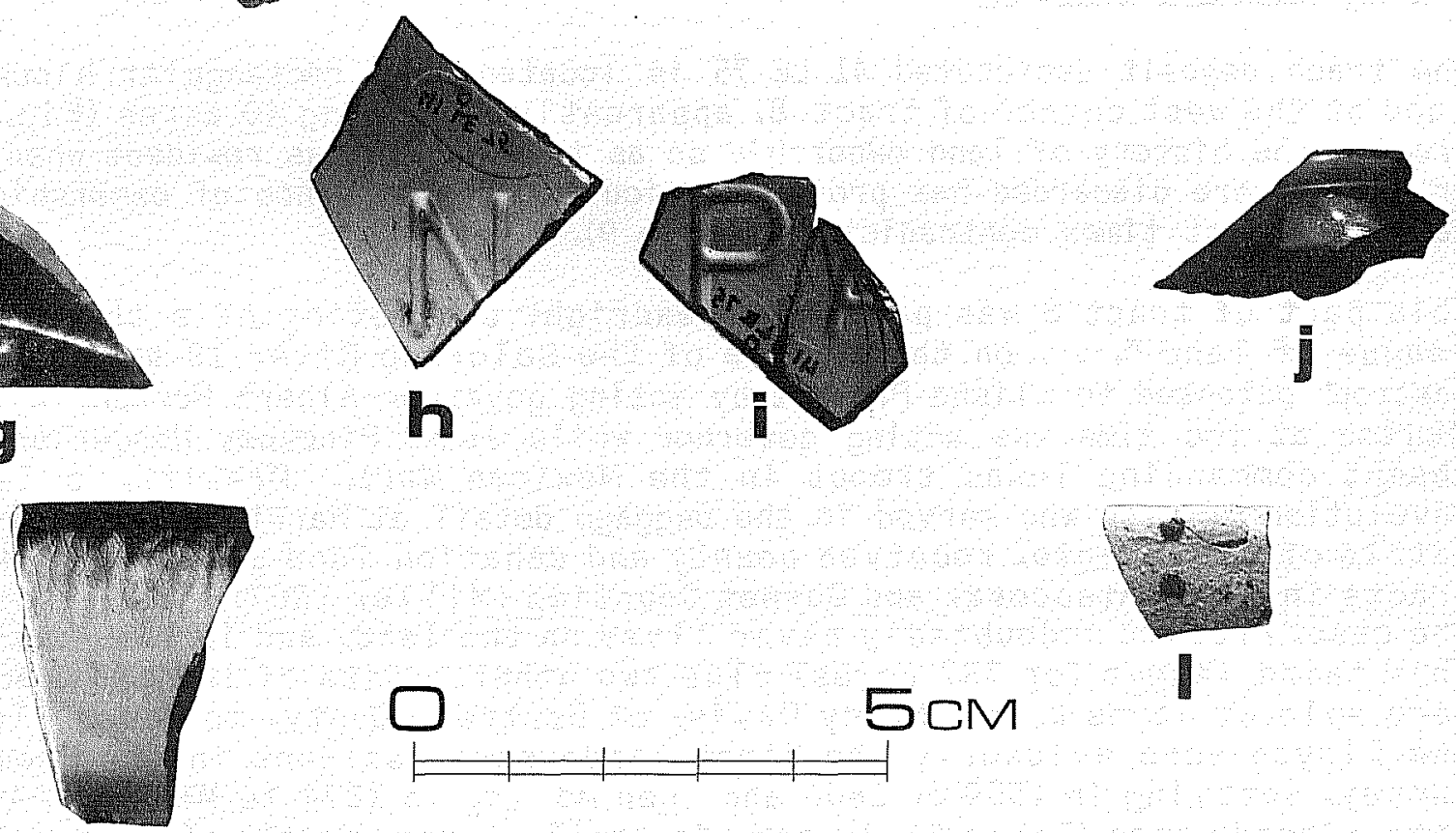

k 
sherd, might also be from a milk bow 1. According to Georgeanna Greer, these are probably from a pottery at McDade operated by Milton Stoker in the late 1880 s to the 1890 s.

\section{G1ass}

The collection includes a pale aquamarine bottle neck with a hand-finished 1 ip (Fig. 1l,e; mold seams stop about one-half inch below the 1 ip). A $1-1 / 2$ inch diameter flange is located three-quarters of an inch below the 1 ip. and below the flange what is left of the body appears to be widely flared. This was probably a low, tapered body, cork-stoppered ink bottle. The neck flange perhaps served as a hand 1e. Another sma 11 aqua sherd may be from the same bottle. Two other pale aquamarine sherds are from one or more panel bottles (Fig. $11, g$ ).

Fifteen purple glass bottle sherds, probably representing at least two bott 1es, most 1 ikely date around 1880-1925 (Newman 1970:74). Figure 11, f shows the base of one of these bottles. Another panel bottle is represented by two pale aquamarine body sherds with raised letters, "PA" and "ON" or "NO."

Also present in the collection are two brown glass snuff bottle rim sherds, one thin, pale olive colored wine bottle sherd, and three brown glass bottle sherds, probably from whiskey or beer bottles.

\section{History of Land Ownership}

The trash deposit designated 41 LE 75 is 1ocated in a rectangular block of 1 and at the west corner of tract 8, apparent $7 y$ measuring 40 acres (Fig. 7 ). Tracing the history of 1 and ownership so as to find who was resident when the artifacts were discarded has proven difficult. The sequence of ownership is tangled and at times contradictory (Table 9).

This part of tract 8 was part of a headright consisting of a third of a league of 1 and ". . . on the E. side of the Colorado River $18 \mathrm{mi} 1$ es N. of Bastrop" patented to Elisha Prewitt by acting governor Albert Horton in 1846 (Horton at the time was acting governor while James Pinckney Henderson was absent commanding Texas troops in the Mexican War). Prewitt, a Texas Revolution veteran who served in the baggage detail at Harrisburg during the batt 1 e of San Jacinto, received bounty and donation 1 and grants for other tracts in Hays, Atascosa, and Burnet Counties (Miller 1967). As was often the case. Prewitt undoubted $1 \mathrm{y}$ never 1 ived on the 1 and, and in 1859 hal $1 \mathrm{f}$ of this third league (or 737 acres) p 1 us two other tracts of 100 and 6 acres were sold by James L. and Nancy Davis, of Bastrop County, to James Floyd. The Floyds were evidentiy the first 1 andowners resident in the Prewitt survey, sett 1 ing in 1859 or 1860 and then moving in 1874 to McDade. As we have a 1 ready seen ( $T a b 1$ e 5 ), he and his family appear in the 1860 census of Burleson County, when he was the largest and wealthiest 1 andowner in the neighborhood. The on $7 y$ slaveholder in the vicinity, he valued his real estate at $\$ 3600$ and his personal estate at $\$ 8965$ in the census, we 11 surpassing the worth of all his neighbors. It was Floyd's son, Young Floyd, 
TABLE 9. TRANSACTIONS INVOLVING PARCEL 1 (PART OF THE PREWITT SURVEY) IN TRACT 8

Date

Ownership

Headright to Elisha Prewitt

James L. and Nancy Davis to James Floyd

James Floyd to John R. George

John G. Willett to Henry M. Tizer

Joseph L. Ferguson to S. C. Garrett

James and Mary K. Floyd to Marion Hughes

James Floyd, Mary K. Floyd,

W. B. and Sarah E. Floyd to

Eugene Bremond, trustee for J. W. Hannig

Marion Hughes to James and Mary K. Floyd

Eugene Bremond to Joseph W. Hannig

J. W. Hannig to Mary F. Ziviey

Amount of

Acreage

Apri1 5, 1875

May 3, 1876

October 9, 1878

October 9, 1878

Ju1y 6,1880

November 6,1880

Mary F. and John H. Zivley to

James $V$. Berger

J. M. Brown, sheriff, to S. A. Alexander and "Levine"

John H. and Mary F. Ziviey vs.

R. S. Wiltis

N. B. Scott

S. C. Garrett

M. J. Elkins

August 19, 1881 John H. and Mary F. Zivley vs.
R. S. Willis
N. B. Scott
S. C. Garrett
M. J. Elkins

November 12, 1881 John H. and Mary F. Ziveley

(sic) vs. Joseph W. Hannig

August 14, 1885 H. L. Lawhon to J. C. Goyens
$1 / 3$ league $=1476$ acres

$737+106$ acres

100 acres

60 acres

40 acres

200 acres

$737+6$ acres

200 acres

$737+6$ acres

$737+6$ acres

$737+6$ acres

743 acres

128.3 acres 150 acres

40 acres

60 acres

128.3 acres 150 acres 40 acres

60 acres
$17+50$ acres 
who was hanged by vigilantes on June 27, 1877, during the Yegua Notchcutter wars, and another son, Jim, reportedly left the country soon after to become a preacher (Bishop 1965:10). Whether the developing Notchcutter conflict influenced the Floyds' decision to sell their 1 and three years earlier and move to McDade is unknown.

During the 26-year period from 1859 to 1885 there are at least 15 separate documents or transactions related to this 7 and, much of it vague or contradictory. The block of 1 and in which the site 1 ies is 1 isted by the Abstract of Title as constituting 40 acres, yet identical metes and bounds (on ly run clockwise instead of counterclockwise) gave an area of 50 acres in 1885 (evident1y an error, as the dimensions given in varas yield an area of 40 acres; tract 8, Abstract of Title n.d.:48; H. L. Lawhon to J. C. Goyens). In other cases the metes and bounds are not given, making it impossible to be certain exactly what parcel of 1 and is described. Some tracts were divided, then recombined, but in a layout which evidently crosscuts the origina 1 boundaries. Without more information than is provided by the Abstract, we cannot identify who was 1 iving near 41 LE 75 at about 1880. Presumably the occupant was John George, H. L. Lawhon, J. C. Goyens, or some descendant or relative of these three; a less 1 ikely possibility is S. C. Garrett, who seems to have 1 ived farther to the southeast (Fig. 7). Of these, perhaps the Lawhon family are the best candidates, although further documentary or oral history research would be necessary to pursue the matter any further.

Another interesting topic touched on by the Abstract of Title is the history of 7 and valuation. The 1 and was first sold in 1859 for $\$ 1.51$ an acre, then part of it was sold the same year for $\$ 2.00$ an acre; then the 1 ot was mortgaged at $\$ 3.36$ an acre to Eugene Bremond, a we11-known Austin entrepreneur and 1 and speculator acting as trustee for Joseph W. Hannig. Hannig was another Austin entrepreneur and 1 and speculator, German by birth, and the fifth and last husband of Susanna Dickinson, famous survivor of the fal 1 of the Alamo (King 1976). James and Mary Floyd, and W. B. and Sarah E. Floyd mortgaged the 1 and to Hannig to pay off a debt of $\$ 2500$, but defaulted, and in May 1876, Hannig acquired the 1 and for $\$ 1000$ (or $\$ 1.34$ an acre), then sold it in 1878 for four times that amount. Two years later the same parcel was sold for a total of $\$ 14.41$ in de 1 inquent taxes, and in the same year 40 acres out of that parce 1 went for $\$ 14.81$ an acre. In 1880 , that same 40 acres was sold for a total of $\$ 2.70$, or about $7 \notin$ an acre. These dramatic fluctuations in 1 and value during the 1 ate 19th century suggest the 1 and functioned for its owners mainly as a 7 iquid asset, and perhaps that improvements on the 1 and never reached a state adequate to fix a minimum value. This may have some relevance for historic archaeology, for it perhaps suggests we can expect to find 1 ittle in the way of permanent remains dating from the late 19th century.

The fence line southwest of the site, as mentioned earlier, is the Bastrop/ Lee County 1 ine, as we 11 as the southwest boundary of tract 8 . At one time a public road ran along this stretch of the county 1 ine, beginning where Highway 696 is now, running northwest $12.5 \mathrm{~km}$ to the Travis County 1 ine; it shows clearly on the 1904 edition of the Bastrop quadrangle, although it is abandoned now and was not noticeable when we visited the site (Fig. 7). Two minor roads intersected it from Bastrop County; one, running roughly eastwest, joined west of the site, and another, running northwest-southeast, 
joined slightly east of the site. The latter is actually an extension of the county road which was 1 ater to become Highway 696, a1though now the highway curves to the east and abandons the old roadway before crossing the county 1 ine. Both roads were abandoned by 1948, when the Elgin quadrangle (15') was published. At the intersection of the 1 atter road with the county 1 ine road, the Bastrop quadrangle shows a single residence on the Lee County side. It too fails to appear on the $1948 \mathrm{Elg}$ in quadrangle. Perhaps this structure was associated with the trash deposited at 41 LE 75, a 1 though none of the artifacts specifical1y suggest a date as 1 ate as 1904 (or 1899, when the field survey was done).

\section{Summary and Recommendations for 41 LE 75}

Examination of the Abstract of Title does not tel1 us who was 1 iving on the 1 and in the 1880s, but has narrowed the 1 ist to a few names (Lawhon, Goyens, George, Garrett). Further research in the federal census records, county records (particularly tax records and surveyors' field notes) at Caldwel1 (Burleson County) and Giddings (Lee County), and interviews with local informants might clarify the matter.

No testing or excavation is recommended, but a second examination of the area on the southwest side of Willow Creek is recommended, to determine whether the homesite associated with the trash dump can be found.

\section{ISOLATED FINDS}

\section{TRACT 2}

The Wolf homestead (4l BP 201, ca. 1900, Kel1y and Roemer 1981:18) is 1ocated on the crest of a hill near the center of tract 2 , and about 275 m eastsoutheast of the old homesite, near the eastern boundary fence, a cluster of ironstone fieldstones was found under a clump of eastern red cedars (Fig. 12,a). This feature is $1.8 \times 1.1 \mathrm{~m}$ across, consisting of a 1 ayer of five boulders with 13 smaller rocks around and underneath; three others have tumbled into an adjacent gul1y. The rocks range in size from about $6 \times 9 \mathrm{~cm}$ to $35 \times 45 \mathrm{~cm}$. There are no ironstone outcrops anywhere in the immediate vicinity, and while none of the rocks by itse $1 \mathrm{f}$ is too 1 arge to carry on foot, it seems likely the lot was hauled in some sort of vehicle. The fill was cleared away from the rocks to a maximum depth of $10 \mathrm{~cm}$ over an area 1.3 $\times 1.7 \mathrm{~m}$ in size in order to reveal the ful1 extent of the feature. The fil1 at the base of the rock cluster is orange brown, clay-rich sand with abundant roots, compact and apparently undisturbed, although a single smal1 fragment of wood charcoal was found at about $10 \mathrm{~cm}$ below the surface, $40 \mathrm{~cm}$ north of the rock cluster. No other evidence of burning and no artifacts of any kind were associated.

Comment: This feature resembles a grave covering, although it is not marked and appears too smal1 for an adult human burial; the size and construction would perhaps be more appropriate for the burial of a household pet of some kind. Excavation and removal of the rocks was not attempted as it was considered to fall outside the scope of the survey. 


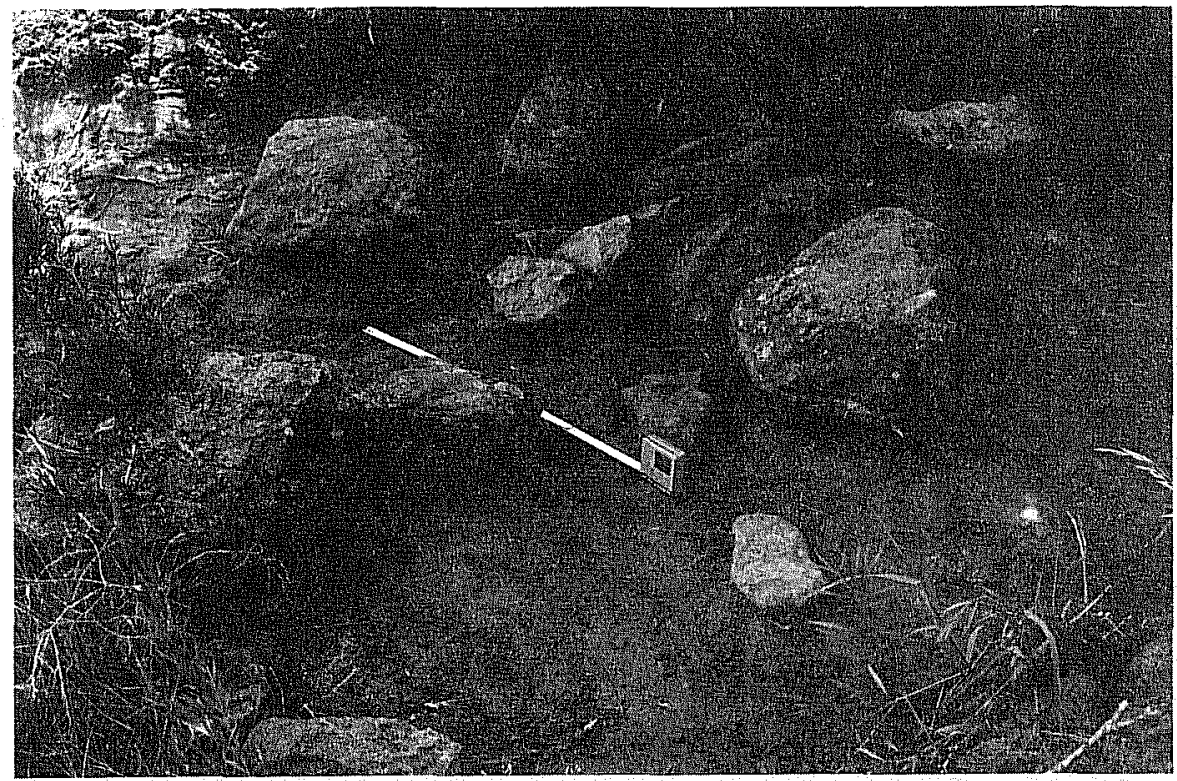

ㄹ.

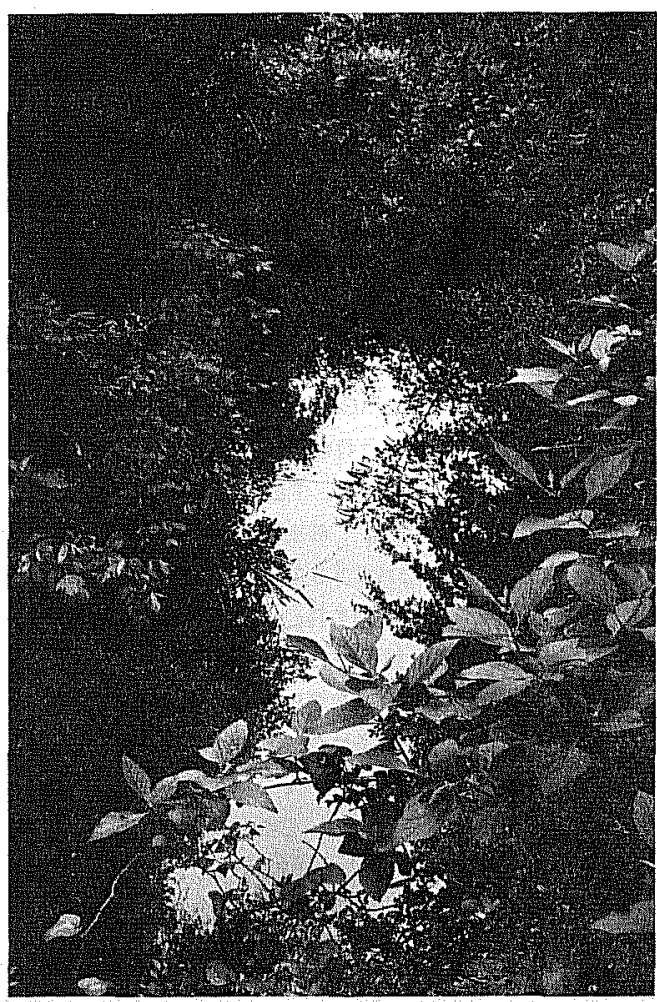

b

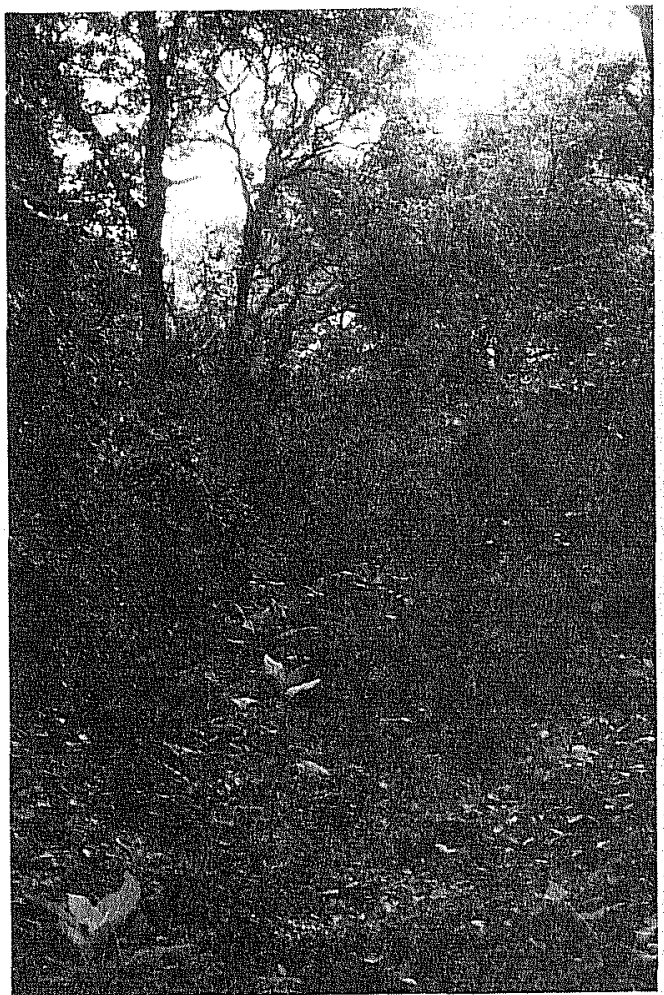

(1)

Figure 12. Isolated Rock Pile in Tract 2 and Views of Survey Area in Tract 8. a, looking west at exposed pile of ironstone boulders in tract 2; tape is $50 \mathrm{~cm}$ long; b, Wi 110 Creek, looking southwest from north bank in tract 8 ; c, looking northeast at dense woodlands bordering open fields near the west corner of tract 8 , north of Willow Creek. 


\section{TRACT 8}

About $300 \mathrm{~m}$ east-northeast of $41 \mathrm{LE} 74$, a single historic sherd was found on the surface, in an $01 \mathrm{~d}$, shallow gully now stabilized by grass cover and invading mesquite. Because it is perhaps the earliest identifiable historic artifact found in tract 8 and perhaps the only artifact that might be 1 inked to early landowners on the north side of Willow Creek. I will review what is known about its history. The specimen is a rim sherd from a blue shell edge plate, or possibly a shallow soup bow 7 , probably about 8 to 10 inches in diameter (Fig. Il,k). This kind of imported English tableware, hand-painted underglaze blue (or somewhat less often green) over a molded relief feathered or scalloped pattern on the rim, is generally termed "edged ware" and was first introduced in the 1 ate 18th century. The earliest known occurrence in Texas is at Mission San Lorenzo in Real County, where three sherds were apparently deposited before 1770 (Tunnell and Newcomb 1969:100, Fig. 40,K). The English ceramic industry continued to make edged ware, first with a glaze termed creamware, later supp 1 anted by a blue-tinted glaze termed pearlware, throughout the early 19th century, and it was still being imported into the United States in the early 1860s (Miller 1980:28) a though presumab 1y the Civil War interrupted its importation into Texas. By the end of the war, edged wares were no longer popular, and they rarely appear in postwar archaeological contexts. In Texas, then, edged ware serves as a fairly reliable marker for pre-Civil War sites, assuming the artifact represented did not have an unusually prolonged uselife. Examples have been found at Washington-on-the-Brazos ( 1 aid out 1835, occupied to present; Davis and Corb in 1967:25-26; however, Fig. IV,C does not resemble the tract 8 specimen), at salt furnaces in the Neches Saline (1820-1870; collection seems to date 1850-1855; Skinner 1971:Fig. 5,C,D), at a trash dump at Fort Inge (1849-1869; Nelson 1981:81, Fig. 36,D), at the Polasek site in Fayette County (built 1850; Carter and Ragsdale 1976:Fig. 10,B), at the William Kincheloe homestead (41 WH 40) in Wharton County (1824-1860; Anne Fox, personal communication), at Fort Lancaster (1855-1862, regarrisoned 1871; Hays and Jelks 1966:Fig. 12,A), and also at a variety of sites for which little or no documented chronology is available, at Palmetto Bend Reservoir (Mal louf, Fox, and Briggs 1973; the tract 8 sherd resemb les Fig. 76,E-G, but not $\mathrm{H}-\mathrm{N}$ ), at Choke Canyon Reservoir (Bandy 1981:Fig. 6,a,c), at Cuero I Reservoir (Fox et a 1. 1974, a though the $i 17$ ustrated specimen, Fig. 84, 7 , does not resemb $7 e$ the tract 8 sherd), at the Sauer homesite in Gillespie County (Tunnel 1 and Jensen 1969:Fig. 17,J), and at Walker Ranch in Bexar County (see Hudson, Lynn, and Scurlock 1974:Fig. 17,h, although the photograph is not available for comparison). One of the largest and most complete collections from an archaeological context in Texas, however, is from La Villita Earthworks (4I BX 677), a probable Mexican siege work associated with the second battle of the Alamo (Anne Fox, personal communication).

Variation in edged wares was considerable. Besides variety in blue and green paint colors and glaze types, mentioned already, and variety in vesse 1 form and function, there are other differences, some of which may have chronological significance. There were two major patterns of edge molding: feather edge and shell edge. Illustrations provided by Noël Hume (1973:Figs. $2-4,9$ ) show what these originally looked 7 ike. While these original patterns were quite distinct, many edged ware sherds found in archaeological context show indistinct molding, to the extent that it is nearly impossible 
to discriminate between she 11 edge and feather edge varieties (the tract 8 specimen is a good example). Presumably this is a result of cumulative wear on the plaster molds used to produce the plates. Excavated examples from mid-19th-century Texas sites, discarded 70 years after the original introduction of the pattern in England, nearly always lack distinctly molded patterns. It is probably for this reason that many archaeologists working with collections of this vintage seem to use the terms "she11 edge" and "feather edge" indiscriminately.

Other varlations in edge relief include molded floral designs or fish scalelike pattern bands. Some rims were round (as in the tract 8 specimen) while others were scalloped. The width of the painted band and the extent to which the individual brush strokes penetrate the interior of the vessel may also vary, perhaps as a function of the painter's work habits. Sussman (1977) provides a useful summary of current knowledge about edged wares with pearlware glaze.

The tract 8 specimen is from a plate or shallow bow 1 with a rim $1-1 / 8$ inches wide, somewhat upwardly concave and a very faint molded shel1 edge pattern with dark cobalt blue paint (Fig. $11, k$ ). The darkest part of the pattern is on $1 y$ 1/8-inch wide, with paint traces extending $1 / 2$ inch in from the $r i m$, which does not appear to be scalloped. The paste is a clear white.

Two stoneware sherds were also found in the Bankston survey part of tract 8 . One (not collected) was at the edge of the same field in which 41 LE 74 was located, about $120 \mathrm{~m}$ northeast of the site. The other (Fig. 11,1) was found on the side of an active gul1y about $425 \mathrm{~m}$ east-northeast of $41 \mathrm{LE} 74$. It is a salt-glazed stoneware rim sherd, apparently from a smal1 preserve jar or similar vessel with a rim diameter around three inches and an open unconstricted orifice. According to Greer (1981:117) stoneware cups were rarely made. Wa11 thickness is $1 / 8$ inch; the paste contains some sma 11 hematite nodules, and the interior has a brownish cast (9YR 5/3) from salt "toasting," and the exterior is $2.5 Y$ 6.5/2. This specimen looks typical of 1 ater wares produced by the Dunkins in Bastrop County (Georgeanna Greer, personal communication).

Two other isolated finds were collected in tract 8. A quartzite cobble has several flakes struck from a prepared platform and also has a heavily battered bifacial edge $5.5 \mathrm{~cm}$ long that probably indicates use as a chopping too1. It was found on the crest of the hil1 near the stoneware rim sherd previously mentioned. A small chert cobble was found in a bare sheetwashed field at the north end of tract 8.

No further work on the isolated finds is recommended.

\section{MORGAN CHAPEL CEMETERY}

Morgan Chape 1 Cemetery (4I BP 200) was first documented by Erwin Roemer, Jr., in 1980 (Ke11y and Roemer 1981:14-18). Our more recent work at the site adds more detail to the documentation, and provides some historical background. We spent $1-1 / 2$ days (July 6-7, 1983) at the cemetery monitoring brush 
clearance by a CPS crew, cleaning debris out of the fenced plots, preparing a plane table map of the cemetery, and photographing each gravestone. Pau 1 Lukowski also made detailed notes on each grave and grave marker, recording inscriptions, motifs, dimensions, and location. The letter designations for graves used by Kelly and Roemer were retained in our records. Since one of our principal goals was to aid the cemetery relocation team in locating any unmarked graves, we spent some time carefully walking over the cemetery area as we 11 as the adjacent part of tract 1 on the opposite side of Highway 696, looking for depressions, mounds, surface exposures of basal clay, isolated bricks, or patches of volunteer irises, any of which might be potential indicators of unmarked graves. Nothing was seen on the surface southeast of the highway, but several depressions, a mound, various stray bricks, and two plots of irises symmetricaliy flanking one of the fenced areas were plotted in the cemetery grounds.

The cemetery is located at the north corner of tract 1. About 300 feet to the northeast is a gravel road. It is now abandoned a short distance southeast of Highway 696, but at one time it was a major thoroughfare for the immediate area, running southeast to McDade and northwest with connections to Pleasant Grove and Redtown. It reportedly was a mail route (Mrs. John Casey, personal communication to Erwin Roemer, Jr., field notes, 1980). East of the cemetery was a fork in the road, connecting with another road which followed the present route of Highway 696 and 7 ed to Mount Pleasant and toward Lee county. The road network appears on the 1904 Bastrop quadrangle, and the cemetery and Morgan Chape 1 are also shown, a though the cemetery is not indicated on the 1907 soil map of Bastrop County. The cemetery is in a three-acre plot of 1 and mostly covered by a stand of medium-sized post oaks and, until cleared by the CPS crew, heavily overgrown by understory vegetation. The cemetery grounds are bounded on the west by a wire fence about 60 feet from the graves, oriented non-cadastral1y (at about $N 21^{\circ}$ $\left.30^{\prime} \mathrm{E}\right)$, and on the east, about 75 feet away, is an a 1 ignment of several o $1 \mathrm{~d}$, very 1 arge post oaks growing in a nearly straight 1 ine oriented roughly north-south (Fig. 13). These were either planted or selectively left standing about 26-27 feet apart along a line which is presumably the effective eastern boundary of the cemetery, since it is at variance with nearby cadastral 1 ines. These trees are probably old enough to date from the establishment of the cemetery. At the south end of this alignment, near the highway but displaced a little to the east, is a large ironstone boulder. A mobile home is located north of the cemetery, and an old frame house is located to the northeast. H. D. Dunbar, of McDade, remembers the chapel as being in the same location as this house, the cistern at the edge of the porch having been immediately outside the north wall of the church building (1etter, James T. Odiorne to Ken Brown, Ju1y 22, 1983). We were unable to examine the house area because of the many clamorous hound dogs that 1 ived there, although a single transferware sherd with a black floral design was picked up between the house and the mobile home.

The history of Morgan Chapel is poorly documented, and the on $7 y$ written account found so far is that of McCrary (1955:40), who says,

Sometime in the [eighteen] seventies a church was built about a mile from the present Mt. Pleasant and about five miles from the brickyards on the Lexington road. John Wolfe, Wm. Cruse, G.B. 


\section{MORGAN CHAPEL \\ CEMETERY}

LARGE POST OAKS

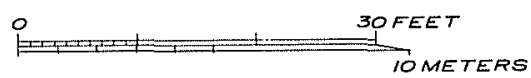

isOLATEO BRICKS
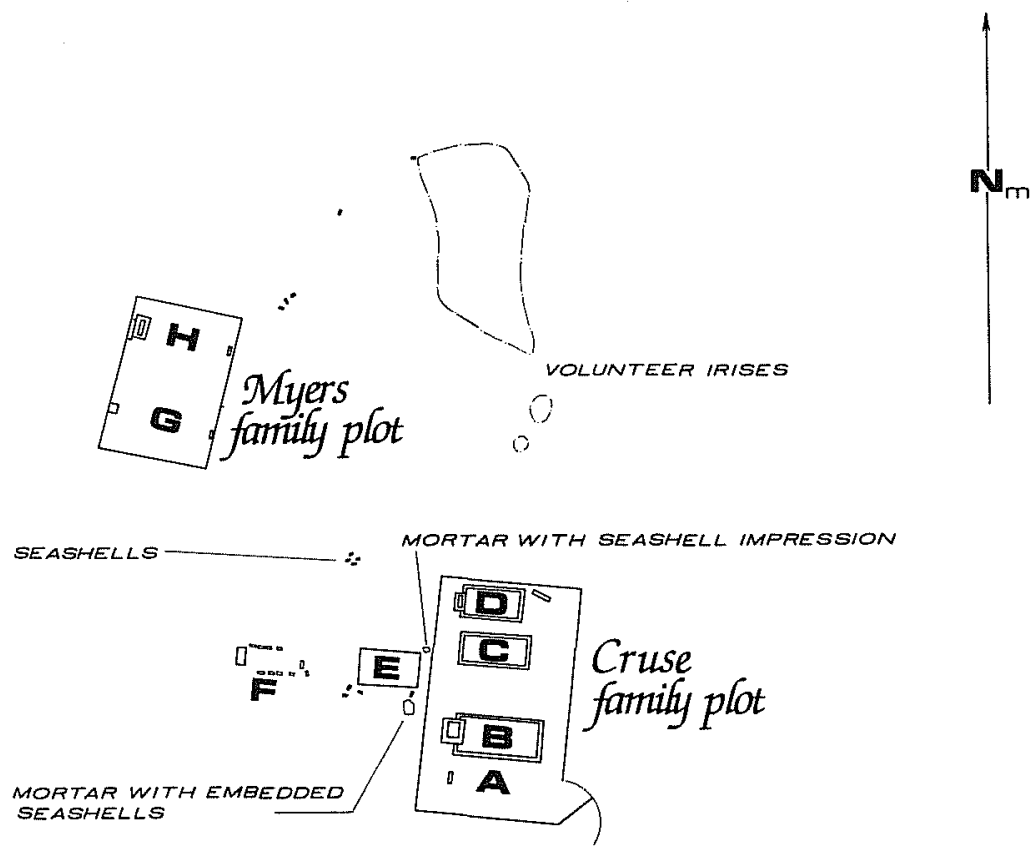

LARGE POST OAK
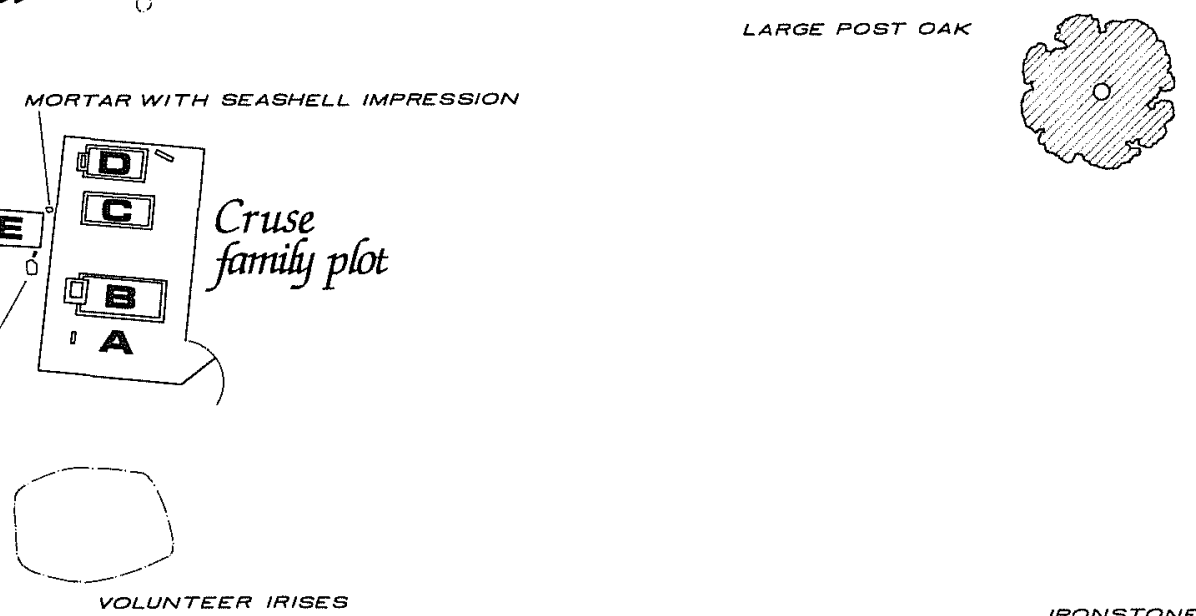

IRONSTONE BOULDER

Figure 13. P1 an of Morgan Chapel Cemetery. The chapel itself reportedly was located just to the northeast of the area shown in this plane table map. 
Bigby, John Meyers and others were among the builders. It was named Morgan's Chapel in honor of the Reverend Daniel Morgan who is believed to have been the organizer of the first Methodist society in Elgin. It was a rectangular frame building with double doors in front and one single door in the back, as so many churches were built then. It was used as a school whenever a teacher was available. A report for 1881 showed that there were 35 children at the Mt. Pleasant school and 25 at Morgan's Chape1. Sam Rucker was one of the preachers there in the early nineties.

On March 28, 1897 a tornado damaged the church and blew away a house in the neighborhood. The church was repaired and continued to serve that community for many more years. Mrs. Cyrena Rankin was a member there until 1916. . . The 1 ast preacher reported was D.G. Hart, on the McDade Circuit, then for many years it was unused and abandoned. In 1941 it was sold by the Methodist Church of Elgin to William Conway and the lumber from it was used to build the Wynn home here in town.

Although this account places the building of the church in the 1870s, an early deed which includes the 1 and where it stood (J. W. Middlebrook et ux to Jones and Sayers, October 27, 1869) indicates the building already existed in 1869:

- . four acres which was donated out of the same by $L C$ Cunningham for church and school purposes which four acres includes the 1 and upon which the building now used as a neighborhood school house and church now stands.

In 1882, John Wolf, having acquired the 1 and, reaffirmed its conveyance to the school trustees (Wm. McWilliams, W. F. Cruse, and C. W. Byers were named), conditional on the continued use of the 1 and (although this deed describes the area as two acres; John Wolf to School Trustees. August 15, 1882). Sometime after 1900, Morgan Chapel was reportedly abandoned when the Mt. Pleasant school was built (affidavit by L. P. Weaver and C. W. Webb, February 16, 1954).

\section{DESCRIPTION OF THE CEMETERY}

There are two fenced family plots ( $F$ ig. $13 ; 15, a)$. Both are rectangu 1 ar, with the long axes oriented north-south, and in both the grave markers face east (note that in Kelly and Roemer 1981:Fig. 5, both the position of Highway 696 and the north arrow are erroneous). Both plots are enclosed by ornate buttressed iron fencework.

The southeasternmost or Cruse family plot is 20 feet 1 ong by 11 feet 10 inches wide; machine-made Butler bricks 1 ine the inside perimeter of the fence. There are four graves; $A$ and $B$ are William F. and Ann (not Anna as in Kelly and Roemer 1981:15) M. Cruse, respectively. Burial of the husband on the right side (facing east) as in this instance is customary for rural cemeteries of the southern folk tradition in Texas (Jordan 1982:30). Grave D 
contains their infant granddaughter, the daughter of Joshaway and Jennie Browning. Grave $C$ is unmarked, and the relationship is uncertain, but the surname may be Baker. Between Graves $C$ and $D$ is an unmarked vacant space nearly four feet wide.

Immediately outside the Cruse family plot, centered on the west side, is a smal1 unmarked brick crypt (E), possibly a false crypt (Jordan 1982:18). Mrs. John Casey (personal communication to Erwin Roemer, Jr., 1980) reported this was the burial of a child named Cassels (Kesse1[?], spelling uncertain). The interior dimension of 52 inches is consistent with a child burial, and the archaic style suggests it is one of the oldest graves, perhaps predating all of those in the Cruse family plot, to which the relationship is not yet known. West of this grave is another child's grave (F), Dasha Lee Johnson, daughter (not son, as in Kel1y and Roemer [1981]) of D. P. and M. E. Johnson (not Dr. M. E. Johnson, as in Kel1y and Roemer [1981]).

Southwest of Grave $F$ is the Dunbar family plot; a11 four graves are unmarked, and there is no enclosure, or in fact any surface indication whatsoever of burials. However, H. D. Dunbar, of McDade, has identified this area of the cemetery as the burial site for his grandmother (d. 1902), a sister (d. 1908 at about two years of age), a brother (d. 1909 at about one year), and another brother (d. 1926 at birth; 1etter, James T. Odiorne to Ken Brown, 1983).

A 1 ittle over 20 feet northwest of the Cruse family plot is another, somewhat smaller family plot (Fig. 13). It too has an iron railing identical to the other one, except there is no gate, and most of the east and west sides have rods tipped with crestlike rather than spearlike emblems. This plot is 13 feet $2-1 / 2$ inches 1 ong by 8 feet $10-1 / 2$ inches wide and has the 1 ong axis north-south, although oriented about $14^{\circ}$ east of present magnetic north (the Cruse plot is oriented about $6^{\circ}$ east of north). There are on $7 y$ two marked graves in this plot (Grave G, Caroline Myers and Grave H, James Ivy), with space for another one or two between them.

West of this plot, and extending a considerable distance to the south, is another area identified by Mr. Dunbar as having unmarked graves (1etter, James T. Odiorne to Ken Brown, 1983). No other details are yet known. About 50-95 feet southeast of the Cruse plot is a 1 arge mound and a group of three shallow depressions varying in size and shape near the present highway. These may not be related to the cemetery, but were mapped anyway. The eastern edge of the tract, between the county road and the alignment of large post oaks mentioned earlier, has experienced considerable disturbance, including a recent drainage ditch from the house located to the north. If any graves were ever located here, they would not be visible from surface indications. 


\section{DESCRIPTIONS OF INDIVIDUAL GRAVES}

\section{Grave A. William F. Cruse (1843-1924)}

The inscription on the gravestone for Grave A reads:

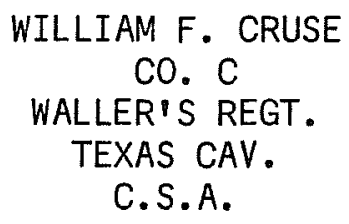

Cruse was born December 1842, in Marshal1 County, Mississippi. In about 1856 the Cruse family came to Texas and settled at Hempstead, then in Austin County but now in Wal1er County. In the 1860 federal census of Austin County, his father, Samue1, is 1 isted as a 54-year-old carpenter born in North Carolina; his mother Mary was 49, also from North Carolina; his sisters E. C. (14) and Ju 1 ia (12) had been born in Mississippi.

On May 3, 1862, at the age of 19, Cruse en 1 isted as a private in the Confederate army at Hempstead (Confederate pension application, file no. 37144, Texas State Archives; Spurlin 1971:73; a though in 1920, Cruse recalled the date as December 1861, evidently an error). He was assigned to Company C of Wal 1er's 13th Texas Cavalry Battalion. The 13th Cava Try is usua 11 y known as Wa11er's Battalion (cf. Fitzhugh 1959; Henderson 1955) because it was at battalion strength during most of the war; on $1 y$ near the end, in 1865, was the unit augmented to regimental strength. Thus the inscription on the gravestone is technically correct, although not the usual designation.

The commander was Col. Edwin Wal1er, Jr. (1825-1875), son of one of the signers of the Texas Declaration of Independence, and owner of a plantation at Hempstead (a)though the 1860 Austin County census on $7 y$ ists him as owning three slaves). The adjutant was Maj. Hannibal Honestus Boone (1834-1897), a Hempstead 1 awyer and 1 aw partner of Wa11er's brother (Spur 1 in 1971).

Company $C$ consisted of recruits primarily drawn from Austin County. The captain was W. A. McDade, First Lieutenant was Thomas S. McDade, and First Sergeant J. C. McDade (Spur1 in 1971:73, 75). Their relationship to James W. McDade, for whom the town is named, is unknown. The other original companies in the battalion were mustered from Victoria, Goliad, Calhoun, San Patricio, Fal1s, and Tarrant Counties.

By July 1862, the battalion was sufficiently organized to march for Louisiana, and on July 1 it left Hempstead, passing through Montgomery, Livingston, Woodvil1e, Jasper, and arriving at Berwicks Bay, Louisiana, on August 31. Once in Lou isiana, Waller's horse soldiers soon saw action against Benjamin Butler's Union troops and participated in a long series of engagements with troops under Butler or his successor, Nathaniel Banks, until the end of 1863. After an initial success at Bayou des Al1emands, Waller's Battalion was ambushed at Bonnet Carre by a greatly superior federal force consisting of five infantry regiments with supporting artil1ery. William Craig, A Company clerk, described the experience as follows: 
- . they seen four Transports and the Steam Frigate Mississippi coming up the river loaded with Troops. . . The whole command was formed in a few moments and we were marched out into a cane field and here we waited until the boats had moved on above us and then the Transports landed their men.... We then turned down a cane row and then the Mississippi opened on us with She 11 \& cannister but did not do us any damage. A French gentlemen met us and said that there was on 1 y 150 Yankees but when the truth was known it proved to be about two thousand \& a battery. Pushed on but could not find ground sufficient to form in 1 ine of batt 1 e. Mounted so a 11 were dismounted and then every fourth man had to hold horses. We then marched about one hundred yards and a11 were stationed along side of the road awaiting an attack. . . . then they opened on us with their Battery \& Minnies and Waller gave the order to fall back to our horses amid Shells \& balls. Some horses had got frightened and run off and some men took most any horse they first met with. By this time shel1s \& Minnie balls were fal1ing in the greatest abundance. . . We retreated down the canal and here we come to the Swamp and Col. Waller finding it impossible to take our horses into the swamp, commanded a 11 to leave their horses and take it a foot. Some led their horses in two or three miles but finding that they could go no further left them. By this time the command was very much scattered in a 11 directions. Col. Waller had some men with him and major Boone also had a portion and almost all of the Captain's had squads all day in getting through the swamps and some arrived at the station about noon and another squad arrived about sundown. A1 1 wet and hungry and remarkably tired. Some came in with no shoes on, no hats and some with hardly any clothes. We come through a swamp that never was trod before by man... We passed through what is called the impenetrable swamps of Louisiana (Spur1 in 1971:48-49).

The battalion's loss of mounts in this action hampered operations during 1862, but in the following year it had frequent encounters with enemy forces, helping to counter Banks' Red River campaign, which was designed to seize Texas cotton-producing 1 ands. In addition to the capture of the Union gunboat Diana, Waller's Battalion participated in engagements at Camp Bisland and subsequent rear-guard actions all the way to Opelousas, and engagements at Cheneyvil1e, Fort Buchanan, Boutte Station, Morgan's Ferry, Sterling's Plantation (near Morganza), Bayou Teche (various firefights), Bayou Bourbeau, Vermil1ionvil1e, Carrion Crow Bayou, and Vermil1ion Bayou. Presumably Cruse participated in most of these batt1es. In December 1863, the battalion returned to Texas to counter an invasion by Banks, and when he again threatened the Red River valley, the battalion returned to Louisiana, participating in major battles at Mansfield and Pleasant Hi11, and further skirmishes at Monett's Ferry, McNutt's Hi11, Mansura, Moreauvil1e, Yellow Bayou, Vidalia, and DeVal1s Bluff, Arkansas. Waller's Battalion 1 ost 10 dead, 31 wounded, and nine missing in action during the Red River campaign (Duaine 1966:88). In November 1864, the battalion was ordered back to Texas and remained there through 1865; in May, the unit was officially disbanded (Spurlin 1971). In his pension application, Cruse reported that his company was disbanded near Waco. 
After the war, perhaps by 1869 , Cruse married and moved to Bastrop County. He is said to have been one of the builders of Morgan Chapel which, as noted previously, had already been built by 1 ate 1869, a 7though his name could not be 1 ocated in partial searches of the 1870 census for Bastrop and Austin Counties. Cruse was a part-time carpenter (Taylor, Cox, and Fox 1986, citing descendants of (ruse), and perhaps it was because of carpentry training he had gotten from his father or from D. B. Linch, a Hempstead neighbor, that he became involved in the building of Morgan Chapel soon afterward. He appears in the 1880 census of Bastrop County ( 8 th Justice Precinct) with his wife, Ann and daughter, Virginia (Jennie, b. 1872); a son, Wil1iam T., was born in January 1877; another son, Sam, was born in May 1882. Also 1 isted as a neighbor in 1880 is John Myers, another builder of the chapel. His wife Caroline, who is buried in the other family plot, is also 1 isted. Both Cruse and Myers are 1isted as "laborers"; in fact, the occupation of nearly every household head in the vicinity is 1 isted as "laborer" or "work on farm," presumably meaning that a 11 were farming on a sharecrop basis. By 1883 , though, Cruse owned his own farm, the 100 acres of 1 and now designated tract 5. Both Cruse and Myers appear in the 1900 census as farm owners. The Cruse family 7 ived in a frame house (4I BP 203) perhaps built by Cruse himself (see the description of tract 5 earlier in this report). Of the Cruse children. Wi11 iam moved to Austin. Sam moved to Parker County, and Jennie married a neighbor, Josh Browning. Wil1iam F. Cruse died Apri1 4, 1924 (affidavit by C. W. Webb, Oct. 20, 1925).

Cruse's grave is marked by a tombstone ( $F$ ig. 14,a), but no footstone or brick border. The tombstone is made of marble, gabled at the top, with a gothic cross inside a circle centered above the inscription; inside the cross is a circular wreath element. The inscription is incised in uppercase letters 1$1 / 8$ inches high.

Grave B. Ann M. Cruse (1848-1914)

The inscription on the gravestone (Fig. 14,b) for Grave B reads

ANN M. CRUSE

BORN JULY 4,1848

DIED JAN. 10,1914

SHE IS AT REST IN HEAVEN.

The surname CRUSE is inscribed on the stepped base in uppercase relief letters three inches high. The name and dates are in engraved uppercase letters 1-1/4 inches high, the motto below (separated by a horizontal engraved 1 ine) is in 5/8-inch uppercase engraved letters except for the initial $\mathrm{S}$, which is $7 / 8$ inch high. The monument is made of sandstone, in three sections, the upper section a nearly square column with the top pitched forward except for an arch at the top of the front face, which has a dove in flight carrying an olive branch, imposed over a gates of heaven motif; the gates are open, exposing a receding roadway. At the base of the upper section is a floral design which extends around the sides; otherwise the sides and back are undecorated. 

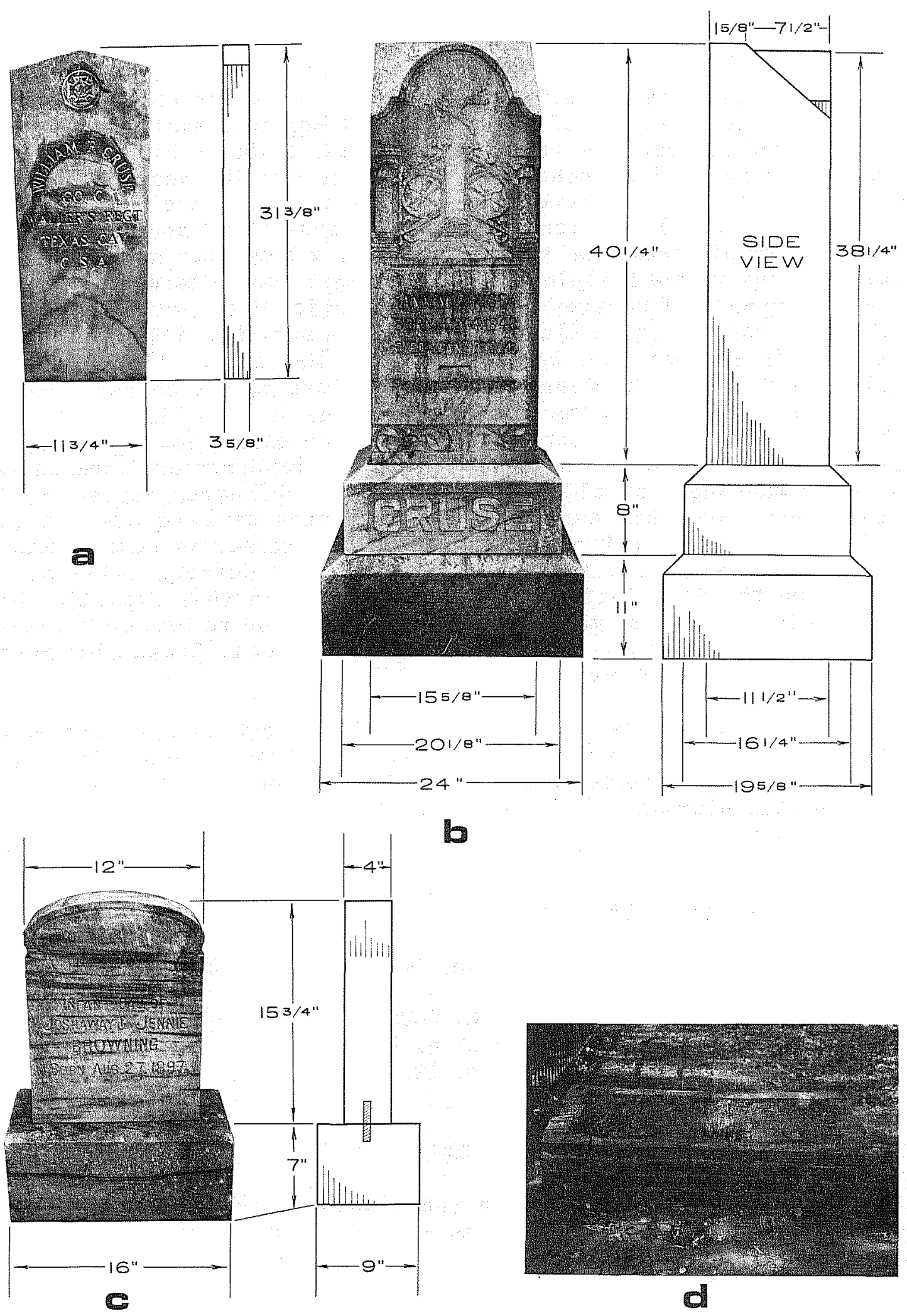

Figure 14. Morgan Chape1 Cemetery. Headstones and crypt (not to scale). a, William Cruse, Grave A; photograph is slightly oblique; b, Ann Cruse, Grave $B$; $c$, Browning infant, granddaughter of Wi11iam and Ann Cruse, Grave D; photograph is slightly oblique; d, brick false crypt, looking south; Grave E (identity unknown). 
The footstone, 2-1/8 inches $\times 7-3 / 4$ inches across and of sandstone, is marked A.M.C. The grave is outlined with Butler bricks planted vertically but canted up onto one corner, enclosing a space 42 inches wide and 77 inches long. An additional border of Butler bricks laid flat encloses the angled bricks on a 11 sides except the south. Irises grow on the part of the grave nearest the marker.

\title{
Grave C. (Unidentified)
}

Grave $C$ has no marker and consists simply of a rectangular area 27-1/2 inches $\times 64$ inches in size out 1 ined by bricks buried standing on one corner, as in the previous examp 1e. These too are machine-pressed Butler bricks, yellowish to cream-colored, and glazed on some surfaces. There is no outer row of bricks 1 aid flat as in Graves B and D. A sma 11, slender squared column of marble was found $7 y$ ing at the foot of Grave $D$ and conceivably might have been the marker for Grave $C$, since it seems too 1 arge for a footstone.

\section{Grave D. Browning infant (1897)}

The inscription on the gravestone for Grave D, the granddaughter of William and Ann Cruse reads:

\author{
INFANT DAU. OF \\ JOSHAWAY \& JENNIE \\ BROWNING \\ BORN AUG. 27, 1897.
}

The Brownings were neighbors of the Cruses, and Josh* Browning owned 1 and immediately to the north of the Cruse farm.

The gravestone (Fig. 14,C), made of sandstone, has an arched top ornamented with a double scrol1, but no other decoration. It is mounted on a concrete base, secured by two iron dowels. The name is engraved with two sizes of uppercase letters, one inch and 3/4 inch high, respectively (the surname in one inch caps), and "Infant Dau. of" and the date are engraved in two sizes of uppercase letters, $3 / 4$ inch and 5/8 inch high. The sandstone footstone, unmarked, is out of $\mathrm{p} 1 \mathrm{ace}$. This grave is a 1 so bordered with angled Butler bricks, surrounded by a second row of bricks laid flat as was done for Grave $B$, except that on the north side next to the fence the outside row of bricks is planted vertically. Interior dimensions for the brick border are 55 inches $\times$ 27-1/2 inches (exterior, 63-1/2 inches $\times 41$ inches).

\section{Grave E. Casse1s(?) Kesse1(?)}

A sma 11 unmarked brick crypt (Fig. 14,d), Grave E, is centered on the west side of the Cruse family plot, and appears to be quite old. It is a child

*Grave marker inscribed Joshaway; documents use the name Josh for the same person. 
burial (Mrs. John Casey, personal communication to Erwin Roemer, Jr., 1980). It consists of six courses of brick above the ground; traces of mortar on the last course and some displaced bricks nearby indicate there was once at least one more course. These red bricks are unmarked and handmade, in contrast to the yellowish machine-pressed Butler bricks which were probably fired at a higher temperature, and most of them show some distortion or cracking that occurred when they were removed from the mold. They measure 8-1/2 inches $x$ 4 inches $\times 2-1 / 2$ inches. The $E 1$ gin area brick industry began at least as early as 1882 with handmade bricks produced by Thomas O'Connor (Elgin Historical Committee 1972:33). In Giddings, the Droemer brickyard reportedly began operation as early as 1870 (Stee1y 1984:121). The crypt is 60-1/2 inches long $\times 35-1 / 4$ inches wide, and the remaining height is 16 inches. The top of the crypt was once covered by a layer of cement or mortar with sea shel1s embedded convex side up. This cap is now gone, except for scattered small pieces and broken shells lying on the ground nearby. The shells are the cross-barred venus, Chione cancel1ata, a species common to the Texas Gulf coast in open bays, bay margins, and inlet-influenced areas (Andrews 1981:134). The shel 1s appear old and weathered and may have been collected from an old shel1 bank ( $\mathrm{J}$ im Markey, personal communication). Covering graves with shel 1s is a common 19th-century southern folk tradition (Jordan 1982:2125). Usual1y the shells are placed unattached, but occasionally may be cemented to grave coverings (cf. Jordan 1982:Fig. 5-7; Kelly and Highley $1979: \mathrm{Fig} .2, \mathrm{a})$.

Grave F. Dasha Lee Johnson (1891-1892)

Grave $F$ is located about 4-1/2 feet west of Grave $E$ and it, too, is centered on the Cruse family plot. When we first examined this grave the marker and bricks appeared to have been displaced from somewhere else, but local informants affirm it is an actual gravesite. The inscription reads:

\author{
DASHA LEE \\ Dau. of \\ D.P. \& M.E. Johnson \\ Born \\ JULY 29, 1891. \\ Died \\ JUNE $20,1892$. \\ Budded on earth to bloom
}

in heaven.

The engraved motto is a common one frequently found on 19th-century children's grave markers. Note that the transcription in Kelly and Roemer (1981:15) is erroneous. The name is engraved in 3/4-inch uppercase letters; "Dau. of," "Born," and "Died" are in italics, and the dates are in 3/4-inch uppercase 1etters, with 7/8-inch initial letters and 7/8-inch numbers. Centered over the inscription is a 5-inch-diameter circular depressed medalition with a relief carving of a dove in flight carrying a branch(?). Bordering the medallion is a dotted motif. This tombstone has an arched top, and rests in a socketed concrete plinth (Fig. 15,b). The footstone, engraved D.L.J.s is located 55 inches to the east and is 5-1/2 inches $\times 2$ inches, extending 10 inches above ground. A mixture of six red handmade bricks (some 
still with mortar adhering) removed from the adjacent crypt and two yellow Butler bricks have been used to out line the grave.

\section{Grave G. Caroline Myers (1833-1904)}

Although Caroline Myers was born in Georgia, John Myers (b. Dec. 1840) was an immigrant from Wurttemberg in southern Germany, an area which contributed a smal1 percentage of German settlers to Texas (many of them from the Heilbronn area of northwestern Wurttemberg; Jordan 1966:33). Some of the Wolf family nearby also came from Wurttemberg, although other Bastrop County Wolfs also came from Prussia, including Nassau, and perhaps from Anhalt. The 1880 Bastrop County census 1 ists the Myers as neighbors of the Cruses, and $A$. W. McLean. Myers' 20-year old stepson, was also a member of the household (United States Department of the Interior, Office of the Census 1880). This and the fact that Caroline was eight years older than John suggests she may formerly have been a widow named McLean who remarried in 1868; this conjecture could be checked by further research. By the 1900 census John and Caroline Myers apparently had moved; although they are still 1 isted in the same precinct (by now the 6th Precinct) as the Cruses, they were no longer 1 isted as adjacent households, appearing instead as dwel1ing \#186, family \#186 (United States Department of the Interior, Office of the Census 1900).

The inscription on the marker for Grave $G$ reads:

$$
\begin{gathered}
\text { Caroline M. } \\
\text { Wife of } \\
\text { John Myers, } \\
\text { born } \\
\text { Apr. 18, 1833, } \\
\text { died } \\
\text { Mar. 4, 1904. }
\end{gathered}
$$

Note that the transcription given in Kelly and Roemer $(1981: 15)$ is incomplete. The dates are engraved in 3/4-inch 1owercase letters with numerals and initial caps 1 inch high; "born" and "died" are in 5/8-inch lowercase letters; the rest of the inscription is in lowercase letters with initial caps, with various letter sizes (1-1/2 inch, 1-1/8 inch, 1 inch, $7 / 8$ inch, and $3 / 4$ inch). On the section below the preceding inscription is the foll lowing verse:

$$
\begin{aligned}
& \text { Fold her, O Father, in thine } \\
& \text { arms, } \\
& \text { And let her henceforth be } \\
& \text { A messenger of love between } \\
& \text { Our human hearts and thee. }
\end{aligned}
$$

This is rendered in 1/2-inch reverse italics with 3/4-inch initial caps. On the basal section below this is the surname, MYERS, in relief sans serif letters 1-7/8 inch high.

The grave marker (Fig. 15,C), one of the most substantial in the cemetery, is a square marble obelisk with fourfold rotational symmetry. Its construction 

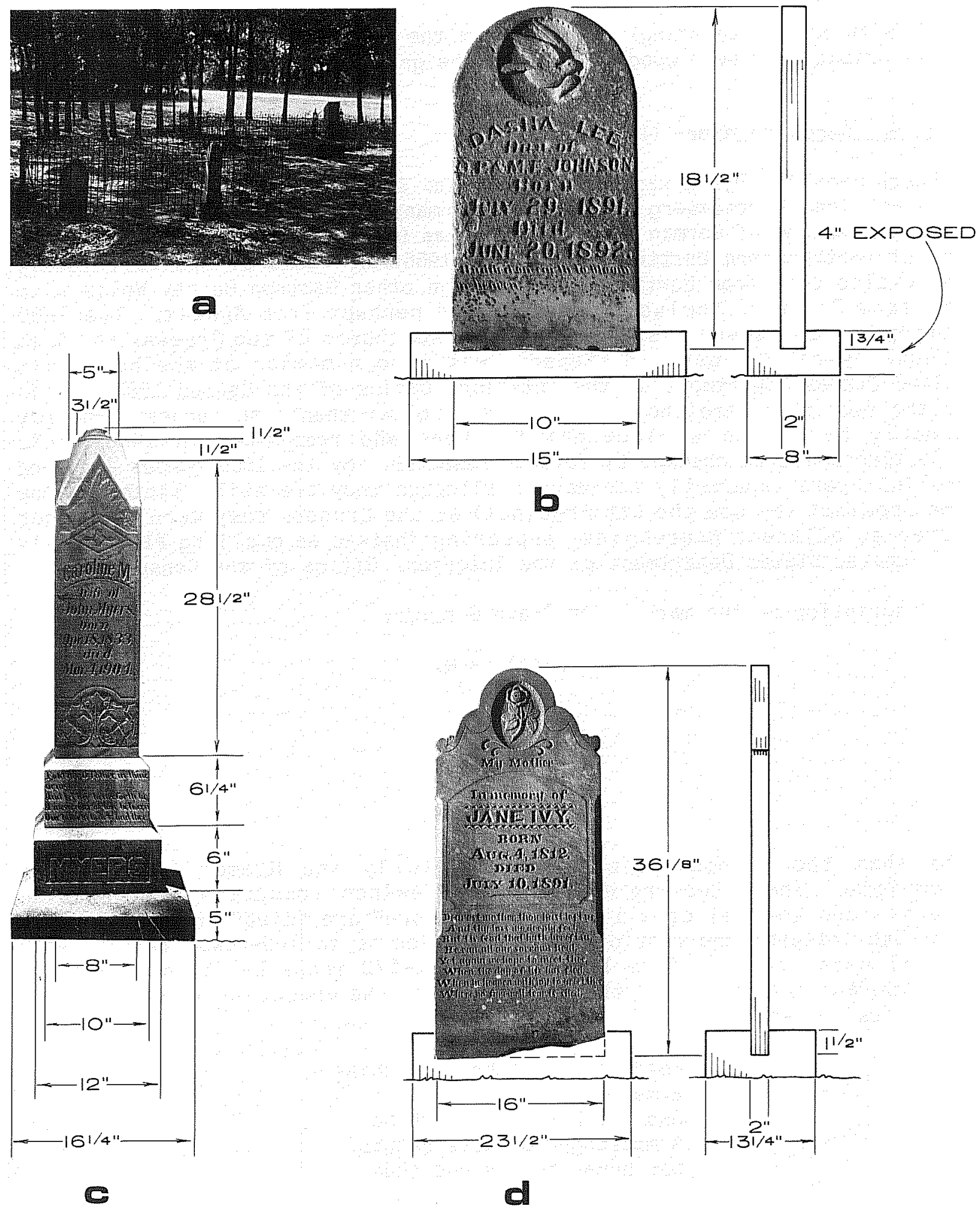

Figure 15. Morgan Chape 1 Cemetery. Cemetery overview and headstones (not to scale). a, view of cemetery looking southeast; Myers family plot in foreground, Cruse family plot in background; b, Dasha Lee Johnson, Grave F; c, Caroline Myers, Grave G; d, Jane Ivy, Grave $H_{0}$ 
is similar to that of Grave B, except this monument consists of five separate sections. The basic design is very similar to two monuments shown at the right-hand side of Figure 5-11 in Jordan (1982).

The uppermost section is a turned circular ornament of unknown design, 3-1/2 inches in diameter, that has been mostly broken off; an iron rod which probably unites a 11 the sections protrudes from the broken surface. The section below is a slender, square column, gabled at the top on a 11 four sides. At the peak of the gable on the front face is a sheaf of wheat chiseled in flat relief; under this is a gothic cross, also in flat relief, centered in a $\mathrm{flattened} \mathrm{diamond.} \mathrm{The} \mathrm{gables} \mathrm{on} \mathrm{the} \mathrm{remaining} \mathrm{three} \mathrm{sides}$ have a similar design, except the wheat motif is replaced by a $1 \mathrm{i} 1 \mathrm{y}$. The center part of the front face carries the inscription with name and dates, and under this is a rectangular block with a central arch, filled with stylized five-sided flowers rendered in flat relief; this motif is repeated on a 11 four sides. Jordan (1982:Fig. 5-32) refers to these as "witches' feet," although the significance of this is unknown. The third section, underneath, carries on $7 y$ the memorial verse on the front face. The fourth section carries only the surname chiseled in flat relief on the front. The fifth section is the plinth, somewhat roughly cut from a block of 1 imestone(?). The footstone, engraved C.M.M., is located 84 inches to the east and is $6-1 / 2$ inches $\times 2-1 / 4$ inches, extending 6 inches above ground.

Grave $\mathrm{H}_{6}$ Jane IVy (1812-1891)

Listed in the 1880 census of Lee County (Justice Precinct 3 ) is a household headed by Joseph Ivey (sic), 43, born in A 1 abama, and including his wife M. J., 34, from Texas, and four sons plus his mother Jane, 67 years old and born in North Carolina. Joseph Ivey (1837-1886) is buried in Knobbs Cemetery, east of tract 8 . Jane Ivy reportedly was the mother of Caroline Myers as wel 1 as Joseph Ivey (Taylor, Cox, and Fox 1986). The inscription on the Grave $H$ marker reads:

\author{
My Mother \\ In memory of \\ JANE IVY \\ BORN \\ AUG. 4, 1812 . \\ DIED \\ JULY 10, 1891.
}

\begin{abstract}
Dearest mother, thou hast left us,
And thy loss we deeply feel,

But 'tis God that hath bereft us,

He can all our sorrows heal,

Yet again we hope to meet thee,

When the day of 7 ife has fled,

When in heaven with joy to greet thee,

Where no farewell tear is shed.
\end{abstract}


The first two 1 ines are in 1/2-inch lowercase letters with 3/4-inch initial caps. The name is in 1-1/8 inch uppercase letters; "born" and "died" are in 3/4-inch uppercase letters; and the dates are in 3/4-inch lowercase letters, with initial caps and numerals 1 inch high. The name is set off above and below by 1 ines composed of rows of punctate triangles (upright above, pendant below).

The marble tombstone ( $F$ ig. 15,d) has a compound arch at the top, with a central oval depressed medal1ion bearing a single rose carved in relief. The medal1ion is 6-5/8 inches $\times 5$ inches across and is bordered with a chain of sma 11 raised triangles; it is flanked on either side by a reverse scrol1, and there are additional engraved scrolls at its base. The name and date inscription has an engraved border, arched at the top with indented basal corners, and the edges of the marker in the area of this inscription are beveled. As in the case of Grave G, the marker is set in a socketed, roughcut 1 imestone plinth. The footstone, also of marble, is engraved J.I. and measures 8 inches $\times 2-1 / 4$ inches, extending 6 inches above ground; it is set 79 inches east of the headstone.

\section{SUMMARY, CONCLUSIONS, AND RECOMMENDATIONS}

In May and June 1983, archaeologists from the Center for Archaeological Research (UTSA) performed a pedestrian survey intended to provide $100 \%$ coverage of 288 hectares of 1 and in the CPS But 1 er 1 ignite prospect. The survey area was divided into five separate tracts in Bastrop and Lee Counties (Fig. 16); four of these tracts had been examined in an earlier reconnaissance-level survey, and the present survey was intended in 7 arge part to emphasize heavily vegetated areas not thoroughly covered by the earlier survey. Five sites were located; all had some prehistoric cultural debris, but two were chiefly mid- to late 19th-century historic sites. Three sites recorded by the earlier survey (Kel1y and Roemer 1981) were briefly reexamined, but a fourth could not be relocated. In July, Morgan Chapel Cemetery, a late 19th/early 20th-century cemetery associated with a nowvanished Methodist church, was mapped and documented in preparation for a planned relocation. Concurrently, a prehistoric site located by the survey in May was also tested.

None of the sites located by the survey appear suitable as a State Archeological Landmark or eligible for nomination to the Nationa 1 Register of Historic Places. Of the prehistoric components, 41 BP 264 and 41 BP 265 are almost wholly destroyed by sand quarrying operations. The prehistoric component at 41 LE 73 has been extensively disturbed by recent historic cultivation and resulting soil displacement. Another site, 41 LE 74, is a very 1 ight scatter of chipping debris that has also been disturbed by erosion and cultivation. Of the historic components, both 41 LE 73 and 41 LE 75 appear to be trash deposits, most or a 11 of which were surface collected during our survey; related structural remains must have existed somewhere nearby, but we have not successfully located them yet. Morgan Chape 1 Cemetery is not considered eligible for nomination since cemeteries in general are not considered eligible for nomination to the National Register, and in any event the cemetery has now been relocated. 

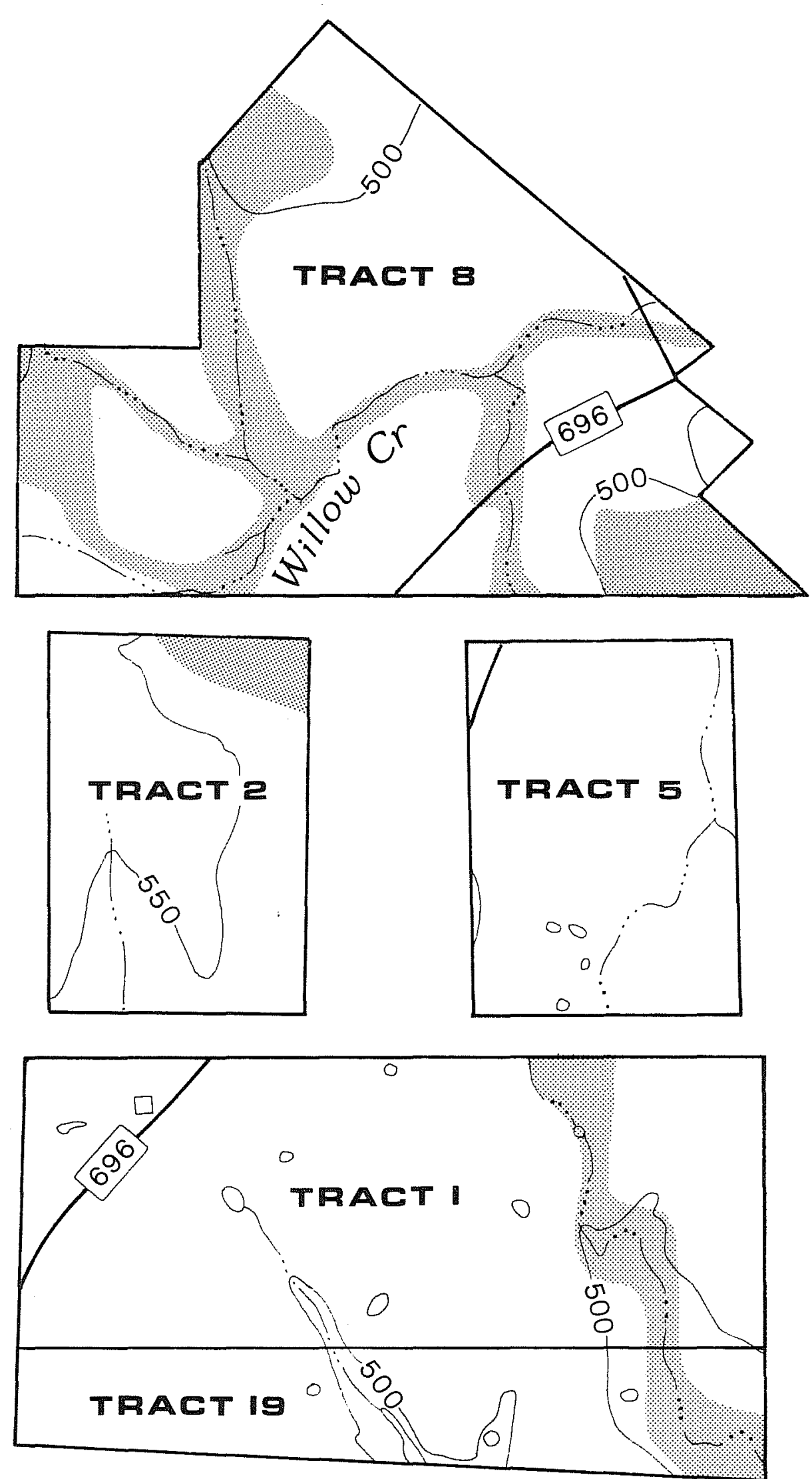

Figure 16. Phase II Survey Intensity. Shaded areas, heavily vegetated and difficult of access, were characterized by poor surface visibility. 


\section{PREHISTORIC OCCUPATIONS}

The earlier survey of the Butler lignite prospect, a 1 though cursory, suggested a very low density of prehistoric occupation. The area included in the phase II survey has two prehistoric sites located by the Kelly and Roemer survey and four more located by us (our survey includes one new tract, 19, but excludes four tracts--3, 4, 6 , and 7--from the previous survey). To see how this site density compares with survey results in the same vegetation region elsewhere in the state, Table 10 has been compiled, summarizing relatively recent archaeological surveys in the Texas post oak belt. Only recent surveys attempting $100 \%$ coverage are included, to reduce the bias implied by differing intensities or methods of survey. Both upland and bottom 1 and terrain are represented. Many of these surveys are in other lignite prospects, since the Coastal Plain post oak and 1 ignite belts 1 argely coincide. Table 10 shows that there is considerable variability both in the areas of the surveys and in the number of sites recorded. Site density in the Butler prospect is about twice the average for the surveys in the table, but the area involved is smaller than that covered by most of the other projects, so there may be some potential for samp 1 ing error. However, the density here is similar to that reported for Camp Swift.

Possible reasons for variance in site density might include the following:

(1) Sampling error; some surveyed areas, particularly smal1 ones, may not accurately sample the true site density in the surrounding region.

(2) Varying definitions of exactly what constitutes a site may account for some discrepancies.

(3) Varying survey coverage, although a11 are assumed here to approach $100 \%$, may account for more. By survey coverage, I mean the area that is actually walked over, regardless of ground visibility.

(4) Varying ground cover.

(5) Varying proportions of different 1 and-use units (e.g.s habitats). This does not seem to be particularly relevant here, since both bottomland and upland terrain is pretty well spread throughout the table.

(6) Varying settlement patterns. Some settlement systems, as in south Texas, may have been based on nearly continuous year-round mobility. Such a system might be expected to produce many insubstantial archaeological sites. Other systems might feature a greater degree of sedentism (at "base camps") during parts of the year, resulting in fewer sites, some of which would be more substantia1. Surveys in northeast Texas (Montice110, Bob Sand 1 in. Mineola. Forest Grove) include some sites occupied by horticultural Caddoan societies whose settlement systems may have differed somewhat from the hunter-gatherer systems under consideration here.

Most of these surveys have al so found that sites in the up 1 and areas away from the floodplains of rivers and their major tributaries are infrequent, shallow, light scatters of chipping debris and/or fire-cracked rock, often 
TABLE 10. PREHISTORIC SITE DENSITY IN THE POST OAK BELT

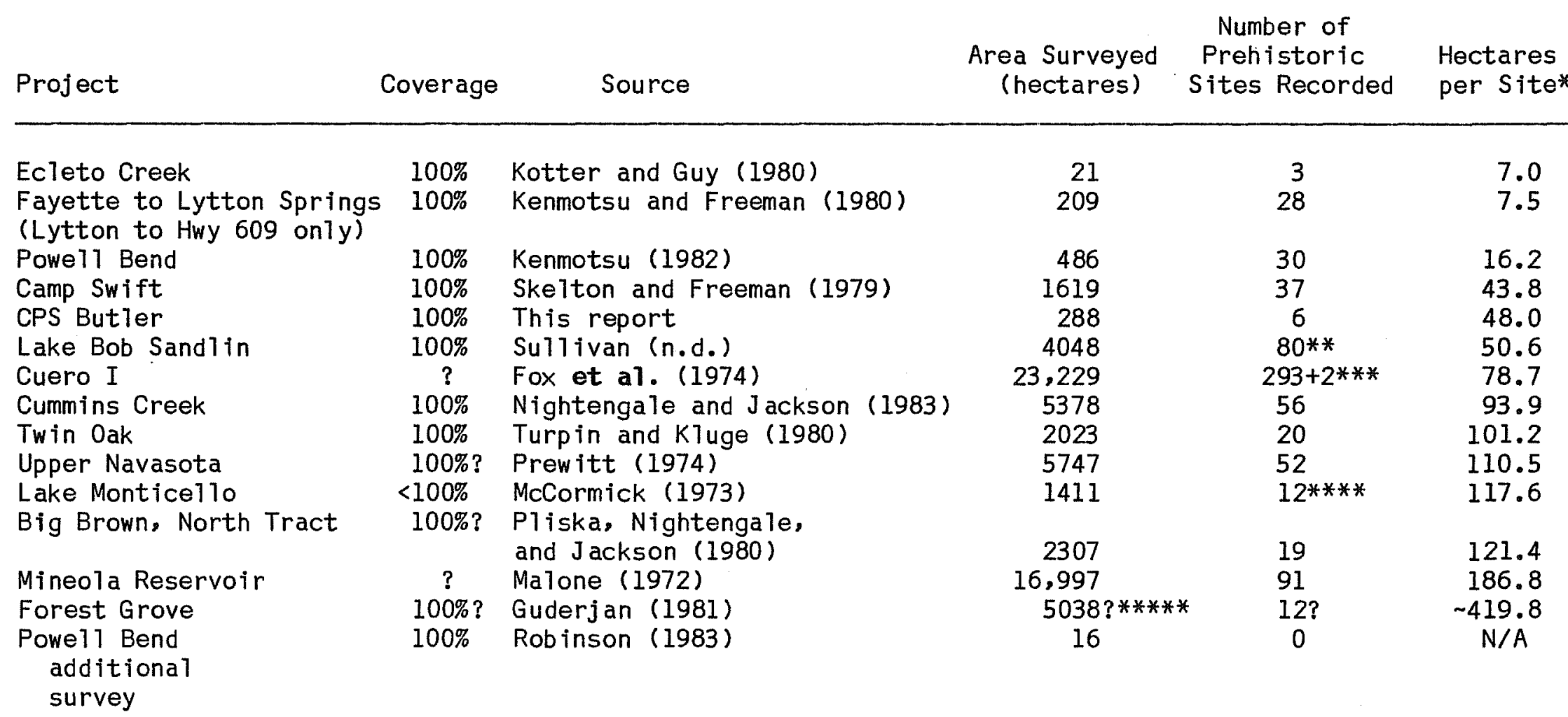

\footnotetext{
* The area surveyed divided by the number of prehistoric sites found; technically, the reciprocal of the site density.

* Approximately 80 sites in reservoir bounds, of which six are wholly historic.

*** Two additional sites found by Kotter (1981).

**** In reservoir bounds.

***** Area of Forest Grove tracts not reported; estimated by planimeter.
} 
1 acking discarded tools which might give a clue to the age of the sites or the activities of their prehistoric occupants (Skelton and Freeman 1979:5253: Kenmotsu 1982:53-55; Nightengale and Jackson 1983:21). Many of these have been classed as "lithic procurement" sites, a term which more than anything else probably means the archaeologist could not identify the function of the site but was impressed with the disproportionate amount of stone toolmaking debris that has survived the processes of decay.

None of the prehistoric sites in our survey area seem to qualify as "1 ithic procurement" sites. The only significant gravel deposit in the project area, at 530 feet elevation in tract 5, showed no evidence of prehistoric use. Gravel outcrops in the project area are not "probably still buried" as Kel1y (Kel1y and Roemer 1981:12) speculates. The Uvalde gravels are thought to be Pliocene and therefore younger, not older than the Eocene deposits on which they rest. They occur as patchy 1 ag deposits draped over the existing erosional topography.

Otherwise, most of the sites have the same characteristics as those documented elsewhere in the post oak belt. A possible exception is 41 BP 264, now essentially destroyed by sand quarrying operations. Although little remained of the site when first encountered in the survey, the number of grinding tools found on the surface is noteworthy. These doubtless must indicate processing of some kind of wild plant food, and such an unusual concentration of these tools might well indicate a former concentration of some wild plant resource in the vicinity. The uniface rejuvenation flakes also suggest some tool maintenance was practiced on the site. The location of the site on the crest of a high hi11 $240 \mathrm{~m}$ from the nearest drainage is striking, and contrasts with survey findings elsewhere in the area. The $\mathrm{Pl}$ ainview point and Clear Fork tool also suggest one or more early components may have been present. Early occupations such as these are not we 11 known in Bastrop County. The best documented site is represented by a surface collection with Plainview, Gower, and Clear Fork tools obtained near Smithville (Duke 1977). If artifacts from 41 BP 264 can be located in 1ocal artifact collections, perhaps we can learn how substantial the early components are, and whether there are additional components not represented in our 1 imited collections.

Another somewhat unusual site is 41 LE 74, a sma 11 prehistoric work station represented mostly by very smal1 biface thinning flakes. We cannot be sure of the number of bifaces crafted here, but the similarity of much of the material suggests only one or two, perhaps. This, too, is a kind of site not we 11 represented in other surveys in the region.

\section{HISTORIC OCCUPATIONS}

Although Bastrop, or Mina as it was then called, was established about 1829 , Anglo-American settlement apparently did not approach the flanks of the Brazos-Colorado divide until about the 1840s. Jenkins (1958:68) mentions an 1841 Indian attack on Fort Ridgeway on Yegua Creek, 15 miles from the Burleson neighborhood (west of Smithville). Pierce locates the site somewhere on the West Yegua, east of McDade or north of Paige (see Pierce 1969:122), but the community known as Ridgeway was near the intersection of 
the present US 290 and Highway 21 . According to The Handbook of Texas, McDade was settled in the early 1840s. To the southwest, in present-day Camp Swift, the earliest settlement occurred about 1839, although it was not until 1860 that the area began to fill up rapidly (Ske1ton and Freeman 1979:90, 92). On the other side of the divide, Martin (in Killen 1974:237) reports that J. A. Tanner and others settled in the Yegua Knobbs area "sometime in the 1840's," and Ki11en (1974:250) maintains Lawhon Springs was first settled by John L. Smith "about 1848." No documentation is provided for these dates, however. While J. A. Tanner was apparently one of the few original grantees actually to settle on his 1 and grant, and while his name appears in the early censuses of Burleson County, I have not yet found when he first settled on the 1 and. By 1860, settlement was dense enough in the Middle Yegua Creek and Mine Creek drainages to support the formation of small communities. A post office was open at Blue Branch by 1860, and in the same year the Knobbs Springs Baptist Church was established (Pieratt, in Killen 1974:236).

Sett 1 ement of sma 11 subsistence farms began in tract 8 , in the CPS project area, at least as early as about 1859, when David Scott and James Floyd acquired their 1 and. Certain 1 y by 1860, the agricultural schedule of the federal census shows a number of farms were in operation. Some settlers, like William Mills or Joseph Scott had only cleared 15 acres by then, suggesting they had not been $1 \mathrm{iving}$ on the 1 and long. James Floyd, on the other hand, with three slaves and a large family, managed to clear 100 acres by 1860 , and with 20 bales of cotton, 75 head of cattle, and 150 head of sheep was participating in the agricultural market economy of the region. Most of the farms probably remained at a subsistence or near-subsistence level until the 1870s or 1880s when the first cotton gins began to be built in the neighborhood, at Pleasant Grove, and on the Scott property just across the 1 ine in Bastrop County (Elgin Historical Committee 1972:39; tract 8, Abstract of Title n.d.:37, Ziviey vs. Willis et al.). Then the area entered the cotton economy until market conditions changed and the soil began to be depleted.

The historical archaeology of tract 8 presents us with several unsolved problems. We know from the census records that there were several family farms in operation by 1860, and that these were occupied and worked we 11 into the 20th century, in one case by the same family but in most cases by a succession of families. Yet almost no trace remains of these early farms except the cleared fields themselves. Structural remains of farm buildings and household trash--the things that archaeologists look for to recognize a site--are almost whol 1 y 1 acking. This is not a unique problem. For a comparative perspective, see Freeman (1983). Some traces of the Mills homestead were found at 41 LE 73, but the conspicuous absence of nails, window glass, and foundation or chimney stones suggests we have found a dump or outbuilding site rather than the actual farmhouse site. Even an early frontier structure lacking glass windows, with a mud-and-stick chimney, ought to at least provide some foundation stones and a few nails. Perhaps the house site has been destroyed by highway construction.

Evidence on the other side of the creek is even more elusive. We know that David Scott acquired his 7 and here in the Bankston survey in October 1859 and farmed it until he sold to Hugh L. Harkins in March 1862. Harkins farmed it for a number of years (see United States Department of the Interior, Office 
of the Census 1870, Burleson County); then in 1897, William H. Harkins sold it to W. J. Hackworth; many other transactions followed as the 1 and changed hands into the 20th century. Despite this evidence of constant occupation, no trace of the earliest farmsteads has been found, except perhaps for a few isolated sherds found on the north side of the creek in the course of a rather thorough search over relatively open ground. Only the 1904 Bastrop quadrangle indicates where one or more dwe 71 ings might have been located--yet nothing was found in the field search.

Except for Morgan Chape 1 Cemetery, and perhaps the Cruse house (41 BP 203), no historic sites older than about 1900 were noted elsewhere in the project area. However, little historical research has been done on any of the tracts except tract 8 , so we cannot be sure when initial settlement occurred in these tracts. Limited examination of the Abstracts of Title for tracts 1, 2, and 5 suggests settlement by about 1879, and certainly the founding of Morgan Chape 1 in about 1869 indicates settlement elsewhere in the Mount Pleasant area by then.

\section{RECOMMENDATIONS}

No testing or ful1-scale excavation appears necessary at any of the sites located by this survey. Al1 of the prehistoric components seem to be essentially destroyed either by sand-quarrying operations, by cultivation, or by erosion induced by cultivation. Both of the historic components found in tract 8 seem 1 ikely to be trash deposits, rather than primary refuse deposits, and in both cases most of the historic artifacts were found in gut1ies.

Earlier drafts of this report recommended further survey in tract 8, possible study of the Cruse house by an architectural historian, a program of ora 1 history, and the initiation of historical research before further field reconnaissance. Most of these recommendations have been obviated by recent developments. Some further survey in tract 8 was done in November 1984. Dismant 1 ing of the Cruse house by the owner has already occurred, allowing us to have a brief look at its construction. Some oral history was recorded by A. J. Taylor during relocation of Morgan Chapel Cemetery, and these efforts proved very useful in understanding the history of the cemetery and the community that it served. I would also recommend that as CPS adds new tracts to its holdings, future archaeological survey might begin with an initial phase of documentary research to assess when the first resident 1 andowners arrived in each tract. This kind of research will help to alert the field archaeologist to what kinds of historical remains might be expected, and where they might be found. I have found the history of 1 and ownership summarized in the Abstracts of Title to be very useful. Careful inspection will usual1y allow an educated guess about when 1 and speculation ceased and actual residency began. In the future other sources of information such as tax records might also be used. Advance preparation should certainly make the field survey more efficient. 


\section{PEAT BOGS AS AN ARCHAEOLOGICAL RESOURCE}

No peat bogs were found in the area we surveyed, and since the project area is generally well drained, with relatively high-gradient streams confined to narrow floodplains, it seems unlikely any peat bogs will be found in areas scheduled for the next phase of survey (a smal1 swamp was found at the northwest edge of tract 8 , but it does not appear to be very old). However, since CPS 1 and acquisitions might eventual ly expand into areas more favorable for bog formation, and since mining operations conceivably might affect bogs in parts of the Middle Yegua watershed outside CPS 1 and, I will brief1y review the significance of nearby bogs.

Archaeological sites are not usually associated with bogs, although several prehistoric artifacts presumed to be "rabbit sticks" have been recovered from a bog near Milano in Milam County (about $50 \mathrm{~km}$ northeast; Chelf 1946). Perhaps these indicate special hunting trips into bogs in search of eastern cottontail rabbit or swamp rabbit, although the function of these items remains unproven. The preeminent significance of peat bogs to the archaeologist, however, is as a paleoenvironmental record. Fossil plant pollen is often poorly preserved in archaeological sites, but peat bogs offer idea 1 preservation environments. Constant saturation with groundwater provides an anerobic environment that inhibits fungal and bacterial degradation, and the constant decay of plant matter at the top of the bog mat provides an acidic environment that also helps prevent deterioration of the pollen exine. Moreover, the abundant organic matter provides a more than adequate supp $7 y$ of samples for radiocarbon dates. A column of matrix samples from the bog provides a record of vegetation history within a variable radius. At Boriack bog, which was mentioned in the introduction to this report, the polien record extended to $15,460 \pm 250$ B.P., in the Late Pleistocene (Bryant 1969:Table 6) and included pollen from alder, birch, and spruce, species no longer found in the area. At Patschke bog, several species of acid-water diatoms were also recovered (Patrick 1946).

The section of Lee County just east of the CPS project area is very favorable for bog formation. Boriack and Patschke bogs 1 ie just to the east, across the Yegua Knobbs; Boriack bog is on 1 y $13 \mathrm{~km}$ due east of tract 8 . Since no throrough inventory of bogs in the area has ever been carried out, there may be many smal1 bogs on private 1 and that are stil1 unknown (informal surveys were carried out by Bureau of Economic Geology staff members in the 1940s and by University of Texas palynologists in the 1960s). USGS maps of the area east of the Yegua Knobbs and southwest of Lexington show frequent ponded and marshy areas along the Middle Yegua and some of its tributaries such as Owens Branch. A secondary area that may have high potential for peat bog formation is along the upper West Yegua and its tributaries (Marshy Branch, Gum Spring Branch, Long Branch) south and southeast of the Yegua Knobbs in both Bastrop and Lee Counties (USGS 7.5' quads, MCDade and Fedor sheets, 1982).

While environmental regulations already require CPS to consider the effects of strip mining on the natural environment, we simply wish to urge that peat bogs be considered during the planning process as an archaeological resource as we 11. Bogs are vulnerable to commercial mining, to changes in water quality (such as release of sulphur or excess particulate matter) which might kill bog vegetation, but especially to changes in groundwater supply and to 
changes in the hydraulic regime which might promote erosion. While Bryant (1969) successfully recovered preserved plant pollen from a bog which was essentially dead, it seems 1 ikely that only continued saturation of Boriack bog with groundwater allowed the pollen to remain undecayed.

\section{REFERENCES CITED}

Abstract of Title

n.d. Abstract of Title for Tract 8. On file at City Public Service Office, San Antonio.

Andrews, Jean

1981 Texas Shel1s. A Field Guide. University of Texas Press, Austin.

Arbingast, Stanley A., Lorrin G. Kennamer, Robert H. Ryan, Alice Lo, David L. Karney, Charles P. Zlatovich, Michael E. Bonine, and Roberta G. Steele

1973 Atlas of Texas. Bureau of Business Research, The University of Texas at Austin.

Austin, Stephen F.

1903 Journal of Stephen F. Austin on His First Trip to Texas, 1821.

Texas Historical Association Quarterly $7(1): 286-307$.

Baker, Frank E.

1979 Soil Survey of Bastrop County, Texas. USDA, Soil Conservation Service, in cooperation with the Texas Agricultural Experiment Station.

Bandy, Philip A.

1981 Historical Archaeological Resources of the Choke Canyon Reservoir in McMullen and Live Oak Counties, Texas. Center for Archaeologica 1 Research, The University of Texas at San Antonio, Choke Canyon Series 2.

Bement, Leland $C$.

1984 Intensive Investigations of 41 BP 191 and 41 BP 192, The Powe 11 Bend Prospect, Bastrop County, Texas. Texas Archeo1 ogical Survey, The University of Texas at Austin, Research Report 87. 
Berlandier, Jean Lou is (Sheila M. Ohlendorf, Josette M. Bigelow, Mary M. Standifer, transiators)

1980 Journey to Mexico During the Years 1826 to 1834. The Texas State Historical Association in cooperation with the Center for Studies in Texas History, The University of Texas at Austin.

Bishop, Luckett P., Sr.

1965 Shoot-out on Christmas Day. Frontier Times (June-July issue):6-11, 59-64.

Bradford, A. L. and T. N. Campbel1

1949 Journal of Lincecum's Travels in Texas, 1835. Southwestern Historical Quarteriy 53(1):180-201.

Brown, David 0 .

1984 A Cultural Resource Survey and Assessment of the Proposed Wolf Lane Substation and Transmission Corridor, Bastrop County,

Texas. Texas Archeological Survey, The University of Texas at Austin, Technical Bulletin 75.

Brown, David 0. and Ray D. Kenmotsu

1980 Test Excavations in the Fayette to Lytton Springs Transmission Corridor, Bastrop and Fayette Counties, Texas. Texas Archeological Survey, The University of Texas at Austin, Research Report 77.

Brown, Kenneth M., Danie1 R. Potter, Grant D. Ha11, and Stephen L. Black

1982 Excavations at 41 LK 67, A Prehistoric Site in the Choke Canyon Reservoir, South Texas. Center for Archaeological Research, The University of Texas at San Antonio, Choke Canyon Series 7.

Bryant, Vaughn $M_{\bullet}, \mathrm{Jr}$.

1969 Late Ful1-Glacial and Postglacial Pol len Analysis of Texas Sediments. Unpublished Ph.D. dissertation. The University of Texas at Austin (botany).

Bureau of Economic Geology

1974 Geologic Atlas of Texas. Austin Sheet. The University of Texas at Austin. 
Campbe11, Thomas N.

1983 Espinosa, 01 ivares and the Colorado River Indians, 1709. La Tierra 10(2):2-12.

Carter, Emily Suzanne and Crystal Sasse Ragsdale

1976 Biege 1 Settlement: Historic Sites Research, Fayette Power Project, Fayette County, Texas. Texas Archeological Survey, The University of Texas at Austin, Research Report 59.

Che1f, Cart

1946 Grooved Clubs from a Peat Bog in Texas. Bul letin of the Texas Archeological and Paleontological Society 17:42-47.

Clopper, Joseph C.

1909 J. C. Clopper's Journal and Book of Memoranda for 1828. Texas Historical Association Quarterly 13(1):44-80.

Davis, E. Mott and James E. Corbin

1967 Archeological Investigations at Washington-on-the-Brazos State Park in 1966. State Building Commission, Archeological Program, Report 5.

Dibble, David S.

1976 Results of an Archeological Survey of Areas to be Affected by a Proposed Sanitary Landfi11, Camp Swift, Texas. Texas Archeological Survey, The University of Texas at Austin, Technical Bul letin 11.

Duaine, Car1 L.

1966 The Dead Men Wore Boots. An Account of the 32nd Texas Volunteer Cava1ry, CSA. 1862-1865. The San Felipe Press, Austin.

Duke, Paul L.

1977 Lake Thunderbird Site (4I BP 78), Bastrop, Texas. La Tierra $4(3): 15-26$.

Elgin Historical Committee

1972 Elgin. A History of Elgin, Texas, 1872-1972.

Faulk, Odie B.

1964 The Last Years of Spanish Texas, 1778-1821. Mouton \& Co., The Hague. 
Fawcett, William B., Jr.

1975 An Archeological Survey of the Proposed Federal Youth Center, Bastrop County, Texas. Texas Archeological Survey, The University of Texas at Austin. Technical Bulletin 10.

Fitzhugh, Lester N.

1959 Texas Batteries, Battalions, Regiments, Commanders and Field Officers, Confederate States Army, 1861-1865. Mirror Press, Midlothian.

Fitzwilliams, Grace

1955 Puesta de1 Colorado Protects Ear7y Trave1 Through Bastrop. Bastrop Advertiser. In the Shadow of the Lost Pines:4.

Fontana, Bernard L., J. Cameron Green leaf, Charles W. Ferguson, Robert A. Wright, and Doris Frederick

1962 Johnny Ward's Ranch. The Kiva 28(1-2; whole volume). Arizona Archaeological and Historical Society, Tucson.

Fox, Daniel E., Robert J. Mallouf, Nancy O' Malley, and William M. Sorrow

1974 Archeological Resources of the Proposed Cuero I Reservoir, DeWitt and Gonzales Counties, Texas. Texas Historical Commission and Texas Water Development Board, Archeologica 1 Survey Report 12.

Freeman, Martha Doty

1983 An Assessment of the Reliability of Archaeological Survey for Locating and Assessing Historic Resources. Appendix $V$ in Inventory and Assessment of Cultural Resources at Addicks Reservoir, Harris County, Texas, by Ross C. Fields. Martha Doty Freeman, and Steven M. Kotter. Prewitt and Associates, Inc.s Reports of Investigations 22:227-233.

Godden, Geoffrey A.

1964 Encyclopaedia of British Pottery and Porcelain Marks. Bonanza Books, New York.

Goode, Glenn T.

1984 Archaeological Testing and Recommendations for the Kennedy Bluffs Site, 41 BP 19, in Bastrop County, Texas. State Department of Highways and Public Transportation. 
Gould, Frank W.

1975 Texas Plants. A Checklist and Ecological Summary. Texas Agricultural Experiment Station. Texas A\&M University (revised edition).

Greer, Georgeanna H.

1981 American Stonewares, the Art and Craft of Utilitarian Potters. Schiffer Publishing, Limited, Exton, Pennsylvania.

Guderjan, Thomas H.

1981 Archaeological Investigations in the Forest Grove/Big Rock Areas, North-Centra 1 Texas. Southern Methodist University, Archaeology Research Program.

Hays, T.R. and Edward B. Jelks

1966 Archeological Exploration at Fort Lancaster, 1966, A Preliminary Report. State Building Commission, Archeological Program, Report 4.

Henderson, Harry McCorry

1955 Texas in the Confederacy. The Naylor Company, San Antonio. Hogan, William R.

1969 The Texas Republic. A Social and Economic History. University of Texas Press, Austin and London.

Holm, Melody

1975 A Preliminary Study of Biologic Assemblages of East Texas Lignite Be1t. Bureau of Economic Geology, University of Texas at Austin, Research Notes 1.

Hudson, William R., Jr., Warren M. Lynn, and Dan Scurlock

1974 Walker Ranch. An Archeological Reconnaissance and Excavations in Northern Bexar County, Texas. Texas Historical Commission, Office of the State Archeologist, Report 26.

Jelks, Edward B.

1962 The Kyle Site, A Stratified Central Texas Aspect Site in $\mathrm{Hill}$ County. Texas. Department of Anthropology. The University of Texas at Austin. Archeology Series 5. 
Jenkins, John Holmes III (editor)

1958 Recollections of Early Texas. The Memoirs of John Holland Jenkins. University of Texas Press, Austin.

Jones, Margaret B. (compiler)

1936 Bastrop. A Compilation of Material Relating to the History of the Town of Bastrop With Letters Written by Terry Rangers. Privately published at Bastrop.

Jordan, Terry G.

1966 German Seed in Texas Soi1. Immigrant Farmers in NineteenthCentury Texas. University of Texas Press, Austin.

1978 Texas Log Buildings. A Folk Architecture. University of Texas Press, Austin.

1982 Texas Graveyards. A Cultural Legacy. University of Texas Press, Austin.

Kegley, George B.

n.d. Letter report of survey of part of South Shore grazing lease at Lake Bastrop (Texas Antiquities Committee Permit No. 157).

Keller, John E. and L. Janice Campbel1 (compilers)

1984 Patterns in Prehistoric Settlement: Examining the Distribution of Sites in a Portion of the Colorado River Valley. The Colorado Coastal Plains Project, Fayette and Colorado Counties, Texas. New World Research, Inc.s Report of Investigations $83-11$.

Kelly, Thomas C. and Lynn Highley

1979 The Jackpump Project. An Archaeological Survey of Portions of Karnes and Gonzales Counties, Texas. Center for Archaeologica 1 Research, The University of Texas at San Antonio, Archaeological Survey Report 65.

Kel1y, Thomas C. and Erwin Roemer, Jr.

1981 Archaeological and Historical Investigations in Bastrop and Lee Counties, Texas. Center for Archaeological Research. The University of Texas at San Antonio, Archaeological Survey Report 101. 
Kenmotsu, Ray D.

1982 Cultural Resource Investigations at the Powe 11 Bend Prospect, Bastrop County, Texas. Texas Archeological Survey, The University of Texas at Austin. Research Report 84.

Kenmotsu, Ray D. and Martha Doty Freeman

1980 Cultural Resource Survey and Monitoring in the Fayette to Lytton Springs Transmission Corridor. Bastrop, Ca 1dwe11, and Fayette Counties, Texas. Texas Archeological Survey, The University of Texas at Austin, Research Report 76.

Killen, Mrs. James C. (editor)

1974 History of Lee County, Texas. Lee County Historical Survey Committee. Nortex Press, Quanah.

King, C. Richard

1976 Susanna Dickinson, Messenger of the Alamo. Shoal Creek Publishers, Inc., Austin.

Knudson, Ruthann

1983 Organizational Variability in Late Paleo-Indian Assemblages. Laboratory of Anthropology, Washington State University, Reports of Investigations 60 .

Kotter, Steven M.

1981 Archeological Survey and Assessment of a Pipeline Right-of-Way Through Portions of the Cuero I Archeological District, Gonzales and Lavaca Counties, Texas. Prewitt and Associates, Inc.s Reports of Investigations 14.

Kotter, Steven M. and J an Guy

1980 Archeological Survey and Assessment of Two Areas to be Affected by Proposed Critical Area Treatment Measures With in the Ecleto Creek Watershed, Karnes County, Texas. Prewitt and Associates, Inc., Reports of Investigations 5.

Latham, Francis $\mathrm{S}$.

1971 Trave1s in the Republic of Texas, 1842. The Encino Press, Austin. 
Laurens, Jane C., Jan A. Guy, and E1ton R. Prewitt

1979 Archeological Survey and Assessment Along Portions of Fayette Electric Cooperative Power Lines, Fayette, Bastrop, and Lavaca Counties, Texas. Prewitt and Associates, Inc., Reports of Investigations 1 .

Mallouf, Robert J., Daniel E. Fox, and Alton K. Briggs

1973 An Assessment of the Cultural Resources of Palmetto Bend Reservoir, Jackson County, Texas. Texas Historical Commission and Texas Water Development Board. Archeological Survey Report 11.

Malone, James $M$.

1972 Archeological Reconnaissance at Proposed Mineola Reservoir. Texas Historical Survey Committee and Texas Water Development Board, Archeological Survey Report 10.

McCormick, 01 in F. III

1973 The Archaeological Resources in the Lake Monticello Area of Titus County, Texas. Southern Methodist University, Contributions in Anthropology 8.

McCrary, Ma11ie (Mrs. George B.)

1955 Golden Anniversary 1905-1955. Privately published history of Elgin Methodist Church.

Menn, Alfred $E$.

1955 Letter Gives Historical Facts of Bastrop's Early Days. Bastrop Advertiser: In the Shadow of the Lost Pines.

Mi11er, George L.

1980 Classification and Economic Scaling of 19 th Century Ceramics. Historical Archaeology 14:1-40.

Miller, Thomas L.

1967 Bounty and Donation Land Grants of Texas, 1835-1888. University of Texas Press, Austin.

Moore, Bill

1977 Bastrop County 1691-1900. Nortex Press, Wichita Fal1s, Texas, (revised edition). 
Mueller, Oswald (translator)

1935 Texas with Particular Reference to German Immigration and the Physical Appearance of the Country. Described Through Personal Observation by Dr. Ferdinand Roemer. Standard Printing Company, San Antonio.

Ne1son, George

1981 Preliminary Archaeologica 1 Survey and Testing at Fort Inge, Texas. Uvalde County Historical Commission.

Newman, T. Stel1

1970 A Dating Key for Post-Eighteenth Century Bottles. Historical Archaeology $4: 70-75$.

Nightengale, Bruce A.

1980 An Archeological Survey of a Transmission Line, Bastrop County, Texas. Texas Archeological Survey, The University of Texas at Austin, Technical Bulletin 39.

Nightenga Te, Bruce A. and Jack M. Jackson

1983 Intensive Survey of Cultural Resources in the Cummins Creek Prospect, Fayette County, Texas. Texas Archeologica 1 Survey, The University of Texas at Austin, Research Report 86.

Noël Hume, Ivor

1973 Creamware to Pearlware: A Williamsburg Perspective. In Ceramics in America, edited by Ian M. G. Quimby. Eighteenth Annual Winterthur Conference Report, 1972. The University Press of Virginia, Charlottesvil1e, Virginia.

Pages, Pierre Marie Francois (Corinna Steele, translator)

1985 A Journey Through Texas in 1767. E1 Campanario 16(1):1-28.

Patrick, Ruth

1946 Diatoms from Patschke Bog, Texas. Notulae Naturae 170. The Academy of Natural Sciences of Philadelphia, Philadelphia.

Pierce, Gerald S.

1969 Texas Under Arms. The Encino Press, Austin. 
Pliska, James R., Bruce A. Nightengale, and Jack M. Jackson

1980 A Cultural Resource Inventory and Assessment of the North Tract, Big Brown Lignite Project. Texas Archeological Survey, The University of Texas at Austin, Research Report 78.

Prewitt, Elton R.

1974 Upper Navasota Reservoir: An Archeological Assessment. Texas Archeological Survey, The University of Texas at Austin, Research Report 47.

n.d. Archeological Survey of Portions of North and South Shore Recreation Areas, Lake Bastrop, Bastrop County, Texas. Letter to Jim Shepperd, Range Conservationist, Lower Colorado River Authority.

Prewitt, Elton R. and Steven M. Kotter

n.d. An Archeological Survey of LCRA South Shore Grazing Area, Bastrop County, Texas. Prewitt and Associates, Inc., Letter Report 7.

Prewitt, Elton R. and Jane Laurens-Day

n.d. An Archeological Survey of the North Shore Grazing Areas, Bastrop County, Texas. Prewitt and Associates, Inc., Letter Report 120.

Raab, Mary C.

1962 Travels and Adventures in Texas in the 1820's, Being the Reminiscences of Mary Crownover Raab With Introduction by Ramsey Yelvington. W. N. Morrison, Waco.

Robinson, David G.

1983 Additional Cultural Resource Investigations on the Powe 11 Bend Prospect, Bastrop County, Texas. Texas Archeological Survey. The University of Texas at Austin. Technical Bul1etin 61.

Shafer, Harry J.

1970 Notes on Uniface Retouch Technology. American Antiquity $35(4): 480-487$.

Ske1ton, Duford W. and Martha Doty Freeman

1979 A Cultural Resource Inventory and Assessment at Camp Swift, Texas. Texas Archeological Survey, The University of Texas at Austin. Research Report 72. 
Skinner, S. Alan

1971 Historical Archeology of the Neches Saline, Smith County, Texas. Texas Historical Survey Committee, Archeological Survey Report 21.

Smith, Ruth and Fay Pannel1

1984 Oak Hil1: A Vanished Community. Sayersvil1e Historical Association Bulletin 5:6-12.

Smithwick, Noah (Nanna Smithwick Donaldson, compiler)

1983 The Evolution of a State or Recollections of 01d Texas Days. University of Texas Press, Austin.

Spurlin, Charles (compiler and editor)

1971. West of the Mississippi with Waller's 13th Texas Cavalry Battalion, CSA. Hill Junior College Monographs in Texas and Confederate History $6 . \mathrm{Hi} 11$ Junior College, Hil1sboro.

Steely, James W. (compiler, with the staff of the Texas Historical Commission)

1984 A Catalog of Texas Properties in the National Register of Historic Places. Texas Historical Commission, Austin.

Sullivan, Timothy L.

n.d. Archaeological Investigations at Lake Bob Sand 1 in. Texas. Department of Anthropology, Southern Methodist University, Archaeology Research Program, Research Report 99.

Sussman, Lynne

1977 Changes in Pearlware Dinnerware, 1780-1830. Historical Archaeology 11:105-111.

Taylor, Anna $\mathrm{J}$.

1986 Archaeological Survey of the CPS Butler Lignite Prospect, Bastrop and Lee Counties, Texas, 1984. Center for Archaeological Research. The University of Texas at San Antonio, Archaeological Survey Report 151.

Taylor, Anna J., I. Waynne Cox, and Anne A. Fox

Archaeological Investigations at Morgan Chapel Cemetery (41 BP 200), A Historic Cemetery in Bastrop County, Texas. Center for Archaeological Research. The University of Texas at San Antonio, Archaeological Survey Report 146. 
Taylor, Lonn and David B. Warren

1975 Texas Furniture. The Cabinetmakers and Their Work, 1840-1880. University of Texas Press, Austin and London.

Texas Almanac

1857 The Texas Almanac for 1857. The Galveston News, W. and D. Richardson, publishers (1986 facsimile reproduction by Glen's Sporting Goods, Inc.).

1867 The Texas Almanac for 1867. The Galveston News, W. and D. Richardson, publishers, Galveston.

Tunne11, Curtis D. and Harald P. Jensen, Jr.

1969 Archeological Excavations in Lyndon B. Johnson State Park, Summer, 1968. State Building Commission. Archeological Program, Report 17.

Tunne11, Curtis D. and W. W. Newcomb, Jr.

1969 A Lipan Apache Mission. San Lorenzo de 1a Santa Cruz. 17621771. Texas Memoria1 Museum, Bu11etin 14.

Turpin, Solveig $A$. and Margaret J. KTuge

1980 Cultural Resource Sampling. Survey and Assessment in Areas to be Affected by the Twin Oak Steam Electric Station. Robertson County, Texas. Texas Archeological Survey, The University of Texas at Austin. Research Report 72.

United States Department of the Interior, Office of the Census

1850 The Seventh Census, 1850. Returns of Schedule One, Population, for Bastrop, Burleson, Caldwe11, and Milam Counties.

1860 The Eighth Census, 1860. Returns of Schedule One, Population, for Bastrop and Burleson Counties; Returns of Schedule Four, Agriculture, for Burleson County.

1870 The Ninth Census, 1870. Returns of Schedule One, Population, for Austin, Bastrop, and Burleson Counties.

1880 The Tenth Census, 1880. Returns of Schedule One, Population, for Bastrop and Lee Counties.

1900 The Twe 1 fth Census, 1900. Returns of Schedule One, Population, for Bastrop County. 
Vasey, Steve

1979a Alum Creek Rich in History. The Bastrop County Times 88(23). Smithville.

1979b Railroad Spurred Rosanky Development. The Bastrop County Times 88(36). Smithville.

Watson, Richard

1965 Bitters Bottles. Thomas Nelson \& Sons, New York and Toronto. Webb, Walter Prescott (editor)

1952 The Handbook of Texas. Vol. 1 and 2. The Texas State Historical Association. Austin.

White, Gifford

19831830 Citizens of Texas. Eakin Press, Austin.

Williams, Annie Lee

1961 The History of Wharton County. No publisher listed; on file at Lee Nesbitt Collection. Nesbitt Memorial Library, Columbus, Texas. 


\section{APPENDIX A \\ INVENTORY OF SURFACE COLLECTION FROM 41 BP 201}

\section{CERAMICS}

2 high-fired earthenware sherds (intermediate in density and vitreousness between ironstone and porcelain); 2 body sherds, including. 1 saucer rim

1 tea leaf ironstone, serving dish $r i m$ sherd

15 plain ironstone sherds (including 1 plate rim, 1 bow [?] rim, 1 plate base, 2 bow [?] base sherds)

1 yellow earthenware bow 1 or pitcher body sherd, ribbed

1 salt-glazed stoneware (crock?) rim sherd with pink and blue banded.rim decoration

1 poorly salt-glazed stoneware crock 1 id sherd (specimen is nearly unglazed and resembles bisque earthenware; probably made at McDade. according to Georgeanna Greer)

8 Bristol-glazed stoneware sherds (including 31 arge crock or bow $1 \mathrm{rim}$ sherds)

2 terra cotta earthenware sherds, salmon-orange slipped exterior, probab $7 y$ both from same vesse1, perhaps a flowerpot; probably a 1 so made at McDade

1 bisque earthenware crock or bow 1 rim sherd

\section{GLASS}

2 milk glass canning jar lid sherds

2 milk glass sherds with molded floral design

3 milk glass sherds (2 flat, 1 curved)

1 ball top canning jar lid sherd

2 pale aqua panel bottle sherds

1 purple pressed glass tumbler or small jar base sherd

1 aqua bottle sherd

I recent clear screw top bottle neck, seams extending over 1 ip

1 purple milk of magnesia bottle neck sherd

METAL

1 zinc canning jar 1 id

\section{PREHISTORIC ARTIFACTS}

1 large heavy percussion, secondary cortex flake of chalcedonic petrified wood

1. possible chert cobble core (may be a machine-fractured cabble) 



\section{APPENDIX B \\ INVENTORY OF SSURFACE COLLECTION, 'TRACT 8, NORTH OF HIGHWAY 696 AND SOUTH OF WILLOW CREEK}

\section{CERAMICS, STONEWARE}

1 Bristol-glazed large crock rim sherd

1 Bristol-glazed bow 1 or crock rim sherd (poorly glazed exterior)

4 Bristol-glazed body sherds

1 base and sidewal1 sherd from a large (ca. 5 gallons?) Bristol-glazed crock

NOTE: At least three vessels seem to be represented here.

\section{CERAMICS, EARTHENWARE}

1. plain ironstone plate base sherd

These artifacts were al1 found in the vicinity of a brick we 11 house near the highway. 
